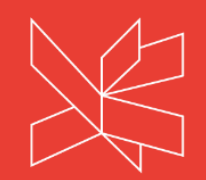

\title{
Fagligt entreprenørskab i erhvervsuddannelserne
}

En kvalitativ analyse af hvordan undervisning gennem entreprenørskab kan påvirke elevers læring, motivation og lyst til at deltage i uddannelse.

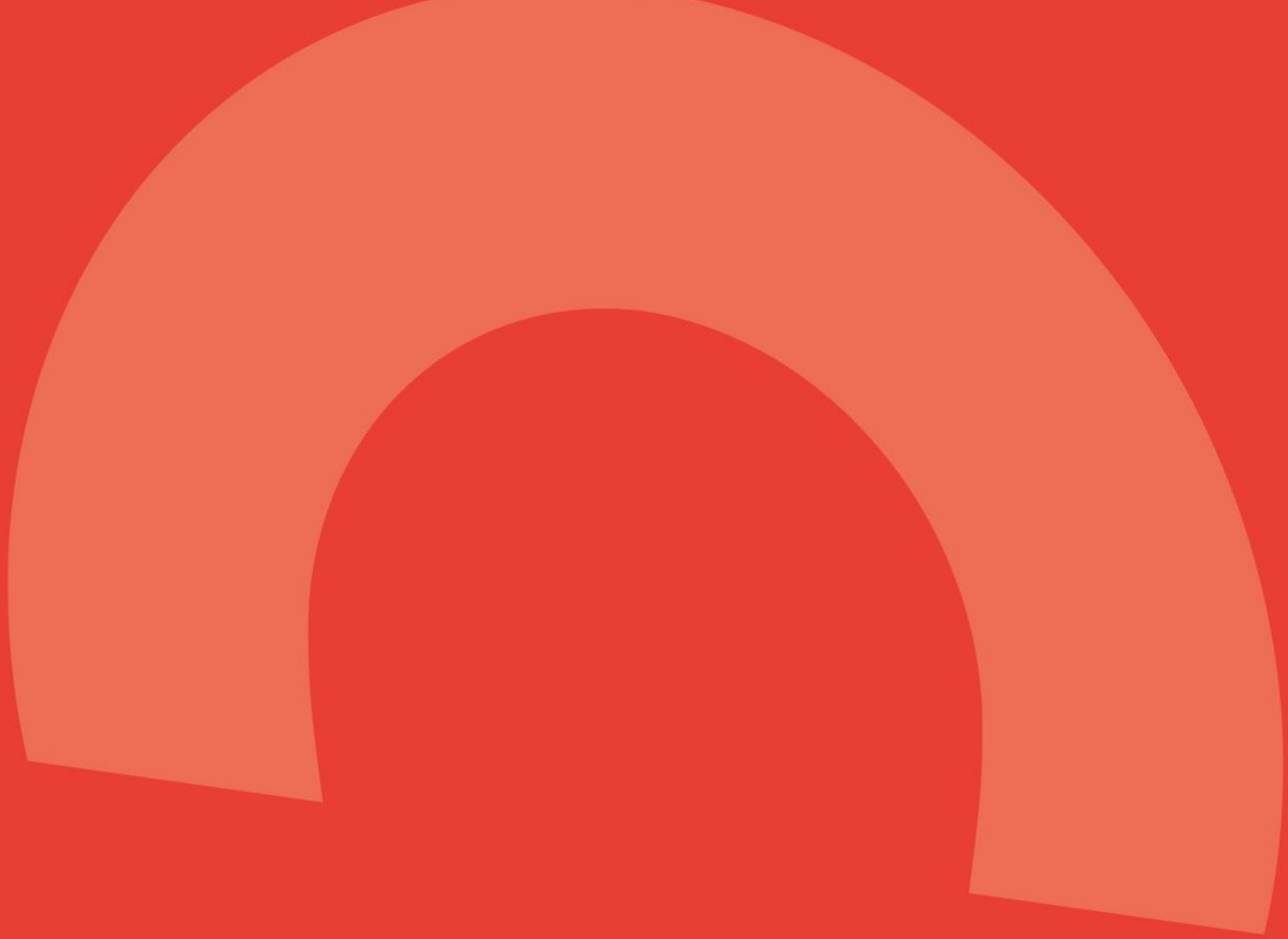

Forskningsprojekt

August 2017 


\section{Kolofon}

August 2017

Fagligt Entreprenørskab i erhvervsuddannelserne

Dorrit Sørensen, Barbara Day,

Susanne Minds, Suna Møller Christensen,

Jane Boniface, Mette Marie Allermand

Nationalt Center for Erhvervspædagogik, Professionshøjskolen Metropol og Efter - og videreuddannelse, VIA University College

For kontakt og spørgsmål til analysen kontakt:

Projektleder Dorrit Sørensen

doso@phmetropol.dk

eller

projektkoordinator Barbara Day

bada@via.dk 


\section{Forord}

På projektets vegne takker vi alle de erhvervsskolelærere og elever som gennem deres erfaring, viden og ambitioner har skabt unikke undervisningseksperimenter som mulige bud på en didaktik omhandlende faglig entreprenørskab målrettet erhvervsuddannelserne, der motiverer, skaber læring og giver eleverne lyst til deltagelse i uddannelse. Det skal fremhæves, at de udvalgte undervisningseksperimenter, er de deltagende læreres bedste bud på at skabe entreprenørskabsundervisning, der er tilpasset konkrete kontekster og elevmålgrupper. Der er i analysen adskillige empiriske eksempler på, at de deltagende elever klart har profiteret heraf.

Nærværende projekt har gennem sine mange detaljerede praksiseksempler udfoldet et blik på undervisning omhandlende entreprenørskab, samt bagvedliggende lærings- og motivationssyn, samt identificeret en række didaktiske greb, forhold og overvejelser, der er vigtige for at arbejde med at udvikle erhvervsskoleelevers entreprenørielle kompetencer fremadrettet. Og når udsagnene kommer fra eleverne selv, får det en særlig overbevisende kraft:

"... Og så på den måde inspirere dem [medarbejdere i daginstitution] til at få ideer. Så viser man dem, at denne her uddannelse [Pædagogisk Assistent Uddannelse] , den kan bruges til at lære, at tænke på denne her måde [entreprenant] og igangsætte nyt med det vi har [idéer og erfaringer] ... I mit praktiksted, der fik jeg at vide at det var så godt, det jeg gjorde. Man får lyst til det, fordi man bliver værdsat” (Elevinterview)

Der er meget engagement, mod og vilje hos de erhvervsskoleelever, som gennem entreprenørskabsundervisning har eksperimenteret, fejlet og prøvet igen, i bestræbelserne på at gøre en forskel for netop det erhvervsfag, som de har valgt. Om det har været at gøre en forskel for andre mennesker, udvikle nye processer, produkter eller materialer, forbedre noget eksisterende, eller igen tænke i fornyelse eller forbedring af mere abstrakte services, så har værdiskabelse været fælles omdrejning for elevernes engagement. Som en lærer udtrykker om eleverne, der arbejder med faglig entreprenørskab:

"Hvis de får skabt ejerskab for et eller andet, så er de unstoppable, men det med relationer er vigtigt, både mellem dem (eleverne) og mellem os (lærerene)"

Forskeren, Bill Lucas definerer kreativitet, som en kombination af at kunne få idéer, at kunne arbejde hårdt og disciplineret med at udvikle dem, at have åbenhed og mod til at turde gå nye veje, og at have fantasi til at kunne lytte til sin egen indre stemme. Og det er i sandhed det som vi har oplevet, at de erhvervsskoleelever- og lærere har bidraget med i form af udvikling, gennemførelse og deltagelse i undervisningseksperimenter, der forhåbentligt kan vise vej og inspirerer til mere fagligt entreprenørskab på erhvervsuddannelserne.

På projektgruppens vegne

Dorrit Sørensen og Barbara Day - sommer 2017 


\section{Indholdsfortegnelse}

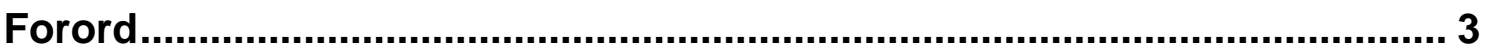

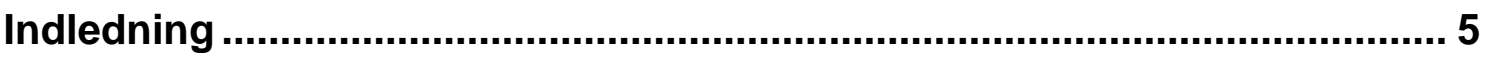

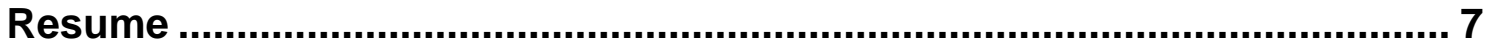

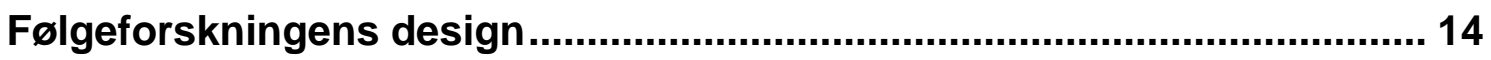

Forskningsspørgsmål i den kvalitative del af følgeforskningen.............................................. 14

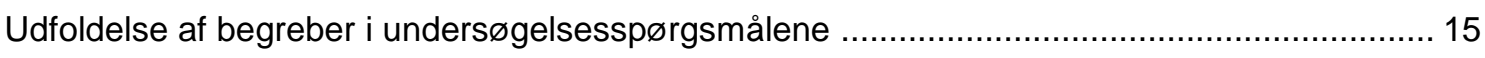

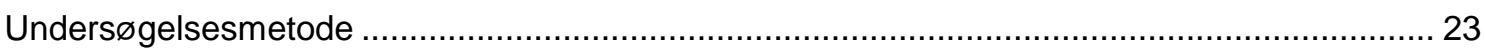

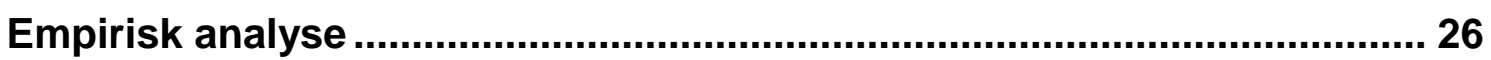

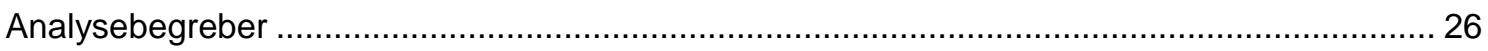

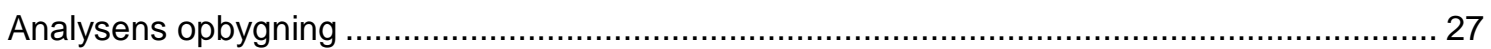

Første blik - Didaktiske billeder på udvikling af entreprenørielle

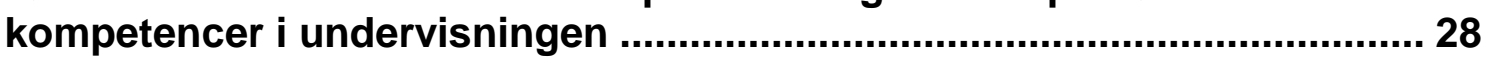

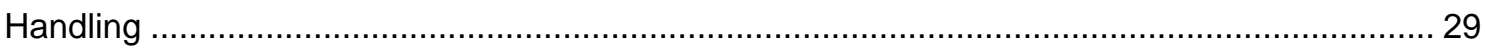

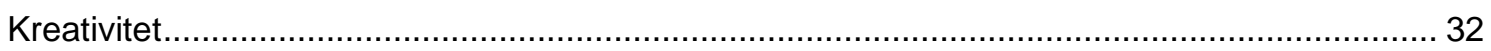

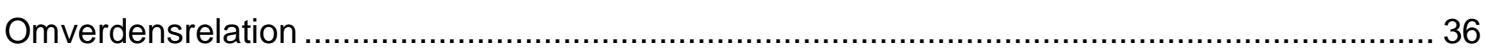

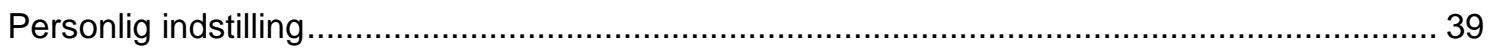

Afrunding på første blik ............................................................................................ 41

Andet blik - Didaktiske billeder på elevers deltagelsesmåder $\mathbf{i}$ undervisning gennem entreprenørskab ................................................... 42

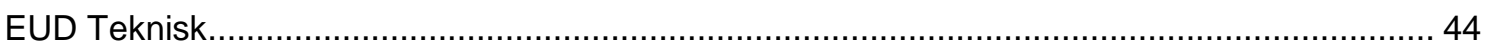

EUD Social og sundhed ……………………………………………………. 52

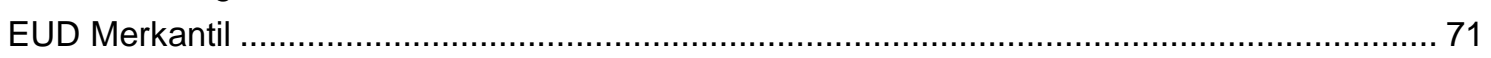

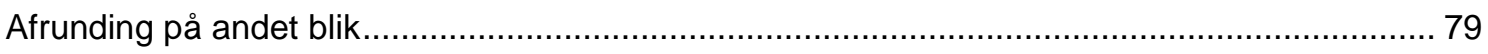

Tredje blik - Didaktiske billeder på hvordan elever med særlige udfordringer, kan profitere af undervisning gennem entreprenørskab..... 80

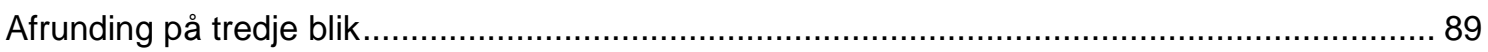

Fra didaktiske greb til fem didaktiske forhold af betydning for udvikling af elevernes entreprenørskabskompetencer .................................................. 90

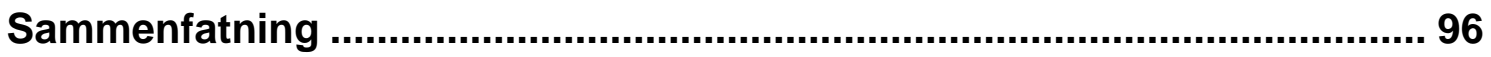

Sammenhængen mellem didaktiske greb og forhold \& motivation og læring ............................ 96

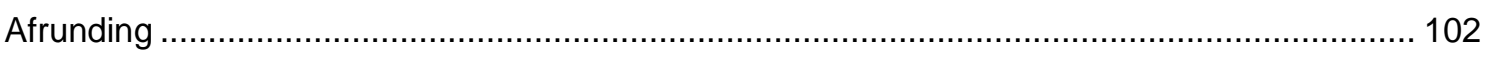

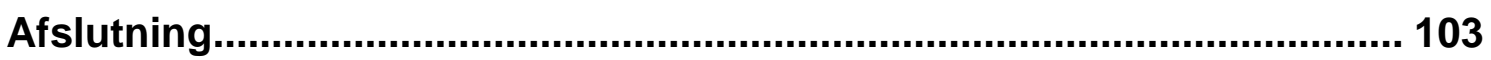

Fra undervisningseksperimenter til entreprenørskabsundervisning .................................... 103

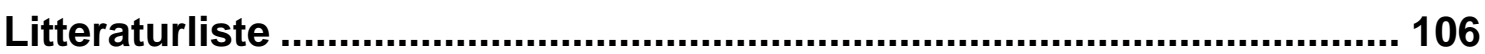




\section{Indledning}

Innovation er en del af regeringens innovationsstrategi "Danmark - Løsningernes Land" (december 2012), hvor det beskrives, at målet er, at innovation skal være et grundelement i alle uddannelser, og specifikt i erhvervsuddannelserne for, at eleverne opnår kompetencer inden for innovation og iværksætteri (Ibid., 2012, s. 25-27). Innovation er ligeledes en del af den nye erhvervsskolereform, der trådte i kraft i sommeren 2015.

Den nyeste effektmåling af entreprenørskabsundervisning i grundskolen fra Fonden for Entreprenørskab (Fonden for Entreprenørskab, 2014) viser, at elever, der modtager undervisning i entreprenørskab, er væsentlig gladere, har højere uddannelses- og jobambitioner, og ser mere lyst på fremtiden. Dette resultat giver grund til en antagelse om, at entreprenørskabsundervisning kan fremme erhvervsskoleelevers motivation og læring, og dermed understøtte, at alle elever uanset baggrund får bedre muligheder for at blive fastholdt i deres uddannelse.

Denne rapport er en afsluttende kvalitativ analyse i forbindelse med følgeforskningen i sammenhæng til udviklingsprojekt 'Fagligt entreprenørskab i erhvervsuddannelserne', der er gennemført som et efteruddannelsesinitiativ for lærere, som underviser på erhvervsuddannelser.

Den kvalitative følgeforskningen ønsker at undersøge sammenhæng mellem entreprenørskabsundervisning, og elevernes motivation og læring. Analysen har følgende forskningsspørgsmål:

Hvordan kan den entreprenørskabsundervisning, som genereres i udviklingsprojektet, påvirke elevers læring, motivation og lyst til at deltage i uddannelse. Herunder hvordan elever, der har særlige udfordringer, kan profitere af denne form for undervisning.

\section{Efteruddannelse i faglig entreprenørskab}

I foråret 2015 udsendte Fonden for Entreprenørskab et udbud om efteruddannelse af erhvervsskolelærere i faglig entreprenørskab. De skrev i deres udbudsmateriale:

For at målet om at inkludere og fastholde udsatte unge i deres erhvervsuddannelse kan opfyldes, er det altafgørende at opbygge en solid efteruddannelse, så elevernes lærere får de kompetencer og redskaber, der skal til for at gennemføre undervisning i entreprenørskab.

Om projektet, skrev de:

- Projektet ønsker ikke at være stigmatiserende i forhold til sårbare unge, men ønsker at tilgå dem via inklusion i den almindelige undervisning.

- Projektet vil undersøge, hvilken effekt entreprenørskab har på udsatte unge og derudover finde metoder og forløb, der giver kompetencer i entreprenørskab til samtlige deltagende elever og afdække metoder, der støtter op om de udsatte unges læring.

I udbudsmaterialet er der en beskrivelse af den entreprenørskabsundervisning, som den i hovedtræk blev praktiseret på erhvervsuddannelserne i 2015: Den entreprenørskabsundervisning der på nuværende tidspunkt foregår på erhvervsuddannelserne, er i høj grad baseret på den enkelte lærers egen indsigt $\mathrm{i}$ innovation, virksomhedsdrift og forretningsopstart, og der findes kun begrænsede efteruddannelsesmuligheder, for lærerne inden for feltet. Derfor har meget af undervisningen i entreprenørskab heller ikke været fuldt integreret $i$ uddannelserne, men har derimod fungeret som særlige, kortvarige forløb. Det kan blandt andet skyldes, at de fleste undervisere ikke er klædt på til at arbejde med iværksætteri, og innovation i undervisningen og koble det sammen med kernefagligheden.

Efteruddannelsesinitiativet omhandler udvikling af et modul 'Fagligt entreprenørskab' til den erhvervspædagogiske diplomuddannelse. I udviklingsperioden er et eksisterende modul fra den 
pædagogiske diplomuddannelse "innovation og didaktik" anvendt. Indholdet og læringsmålene på modulet i udviklingsperioden er blevet tonet mod entreprenørskab.

Der er i perioden januar til december 2016 gennemført fire diplommoduler som pilotforløb. Forløbene har været fordelt med henholdsvis to hold på National Center for ErhvervspædagogikNCE ved Metropol og to hold på VIA. 73 erhvervsskolelærere har gennemført diplomforløbet. I forår 2017, er der ansøgt i det faglige fællesudvalg for de pædagogiske diplomuddannelser om godkendelse af et nyt valgmodul til diplomuddannelsen i erhvervspædagogik med afsæt i pilotforløbene. Det er nu godkendt under titlen Faglig entreprenørskab i de erhvervsrettede uddannelser.

\section{Undervisningseksperimenter omhandlende entreprenørskab}

Igennem deltagelse i efteruddannelsesinitiativet har erhvervsskolelærerne opnået viden og erfaringer, som de løbende har omsat til udvikling af didaktisk praksis rettet mod udvikling af elevernes entreprenørielle kompetencer, bl.a. efter inspiration fra Fonden for entreprenørskabs fire komplementære, og indbyrdes afhængige kompetenceområder, betegnet som entreprenørielle dimensioner - Handling, kreativitet, personlig indstilling og omverdens-relation (Fonden for Entreprenørskab, 2016). Konkret har lærerne gjort dette ved at gennemføre undervisningseksperimenter, efter eksperimenthjulet (Hutters og Sørensen 2015).

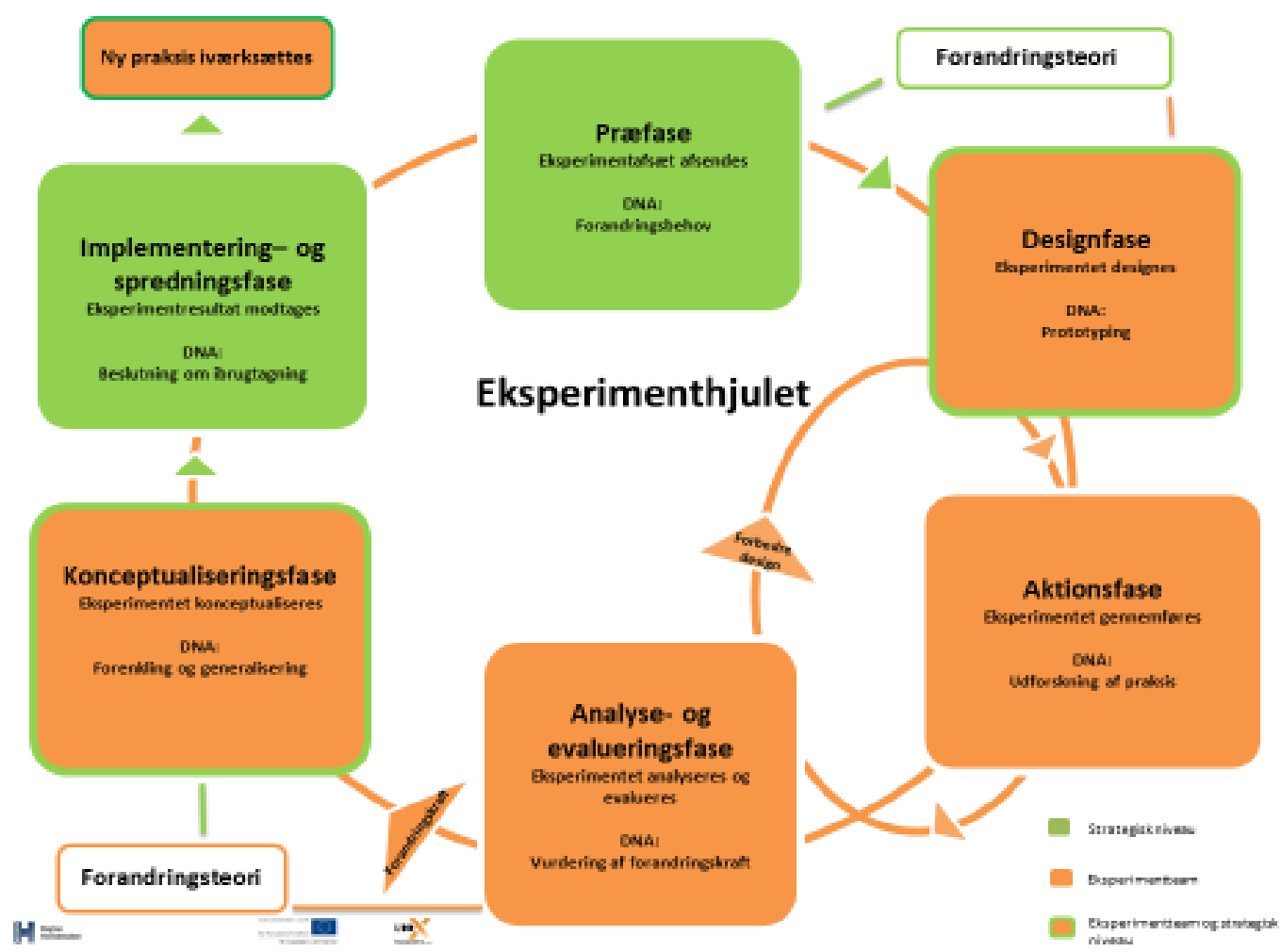

Undervisningseksperimenterne er gennemført i lærernes lokal kontekst - altså på de skoler, de arbejder på til dagligt.

Et eksempel på et undervisningseksperiment er f.eks. udviklingen af et undervisningsforløb, hvor lærerne har designet lærerprocesser for eleverne, med det formål at fremme deres kreativitet og foretagsomhed i samspil med institutioner eller virksomheder. De didaktiske tiltag, f.eks. elevernes konkrete afprøvning af en idé, er sket gennem aktioner jf. eksperimenthjulet. 
Eksperimenthjulet er inspireret af designbaseret forskning (DBR) som er karakteriseret ved afprøvning, evaluering, analyse og forbedring (Cobb, P. 2003). Designprocessen i eksperimenter kan også beskrives som, at ny viden hos lærerne genereres gennem processer, som udvikler, afprøver og forbedrer et design (Brown \& Collins, 1992) her udlagt som ny didaktisk praksis omhandlende entreprenørskabsdidaktik.

Udviklingstilgangen betyder, at de udviklede designs $\mathrm{i}$ form af undervisningseksperimenter afprøves i praksis, og at erfaringerne herfra bruges til at forbedre undervisningsforløb omhandlende entreprenørskab på erhvervsuddannelserne.

Undervisningseksperimenterne, der er gennemført under lærernes efteruddannelse omkring entreprenørskab, repræsenterer alle tre uddannelsesretninger inden for erhvervsuddannelserne; Teknisk, Merkantil samt Social og Sundhed.

\section{Erhvervsskolelæreren som udforsker af egen praksis}

Den ramme og det felt som følgeforskningen arbejder i, er altså udvalgte erhvervsskolelæreres hverdagspraksis, hvor lærerne eksperimenterer med henblik på, at udvikle en entreprenørskabsdidaktik målrettet erhvervsuddannelserne. Der er en række erhvervs- og uddannelsesrelaterede læringsmål - knyttet direkte til den konkrete uddannelse, som eleven deltager $i$, dvs. erhvervs- og uddannelsesrelaterede læringsmål. Det er de læringsmål, eleven konkret arbejder gennem og omkring, for at udvikle og forbedre sine entreprenørielle kompetencer. Iscenesættelse af entreprenørskabsundervisning kan derfor have mange forskellige udtryk, og de didaktiske greb i undervisningen vil være utallige og mangfoldige.

Den eksperimenterende form, hvor lærerens konkrete aktioner har til formål at levere forståelse såvel som forbedring, netop i kraft af læreren som udforsker af sin praksis, er central at holde fast $i$, så tranfer kommer til at virke som en abduktiv kraft, der sikrer dynamikker mellem rollerne som deltager på diplommodul, udforsker og udvikler af egen praksis. I de konkrete undervisningsforløb, der er søsat i projektet, er det lærernes eget design for entreprenørskabsundervisning, som er prøvet af. Deltagende lærere har været udforskere i egen praksis - og derfor skal undervisningseksperimenterne netop forstås som lærerens bud på en praksis for entreprenørskabsundervisning, der afspejler de mulighedsbetingelser, deres praksis giver.

\section{Forstudie som afsæt for den kvalitative analyse}

Der er i forbindelsen med analysen udarbejdet et forstudie (Day, Larsen og Sørensen 2016), hvor vi gør rede for vores forskningsafsæt, i form af den seneste forskning i fastholdelse af elever i det danske erhvervssystem, set i sammenhæng med didaktisk praksis. På baggrund af denne forskning, samt projektets afsæt i Fonden for Entreprenørskabs forståelser, finder vi det relevant at trække på teoridannelser omkring motivation og læring. Formålet er, at anvende disse teoretiske forståelser, som viden vi diskuterer vores empiriske fund med. De teoretiske forståelser bruger vi også til løbende at fremhæver implikationer, og perspektiverer i forhold til entreprenørskabsundervisning.

\section{Resume}

Nationalt Center for Erhvervspædagogik (NCE), Professionshøjskolen Metropol og Efter - og videreuddannelse, VIA University College har i perioden 2015 - 2017 fortaget en kvalitativ analyse af udvalgte elevers motivation og læring, i sammenhæng med deres deltagelse i undervisning omhandlende entreprenørskab. Den undervisning som eleverne har deltaget $i$, har været under konstruktion ved, at lærerne har afprøvet didaktiske design under deres efteruddannelse med det formål, at fremme en undervisningspraksis, der udvikler elevernes entreprenørielle kompetencer. 


\section{Formål, felt og form}

Følgeforskningen har haft til hensigt, at undersøge hvilken betydning entreprenørskabsundervisning, kan have på de deltagende erhvervsskoleelevers, læring, motivation og lyst til deltage i uddannelse, uanset deres forudsætninger.

Den kvalitative forskningsdel forholder sig altså undersøgende til, hvordan undervisning omhandlende entreprenørskab, fremmer motivation og læring hos elever - herunder elever med særlige udfordringer. Undersøgelsen tager, som skrevet indledningsvis, afsæt i en antagelse om, at læring og motivation er faktorer, der kan have indflydelse på elevers lyst til deltagelse i uddannelse. Denne antagelse bygger på effektmåling, af entreprenørskabsundervisning i grundskolen fra Fonden for Entreprenørskab (Fonden for Entreprenørskab, 2014). Analysen bygger samtidig på en antagelse, fremskrevet i et forstudie udarbejdet til denne analyse om, at der kan være en sammenhæng mellem elevernes motion og læring, samt lyst til deltagelse i uddannelse og deres fastholdelse i uddannelse, herunder fastholdelse af elever med særlige udfordringer, da de kan være i en øget risiko for frafald, hvis undervisningen ikke motiverer og inkluderer alle elever, uanset forudsætninger (Day, Larsen og Sørensen 2016).

Det skal fremhæves, at den kvalitative forskningsdel foregår, som allerede skrevet i sammenhæng til lærernes efteruddannelse i entreprenørskab, og at de interventioner i form af undervisningseksperimenter, som lærerne har gennemført i deres praksis, har haft til formål at sikre transfer på en måde, hvor lærerne oversætter og bruger det, der er betydningsfuldt fra diplomforløbet, som inspiration til at udvikle deres egen praksis og vice versa. Det er altså de undervisningseksperimenter, som lærerne udvikler under deres efteruddannelsesforløb som der følges. Det betyder helt konkret, at elevernes deltagelse i undervisning gennem entreprenørskab har begrænset tid, og det ligger uden for dette forskningsprojekt, at undersøge effekten af elevers deltagelse i undervisning gennem entreprenørskab på længere sigt.

Analysens fund vil ikke fremstille et repræsentativt billede af, hvordan entreprenørskabsundervisning ser ud i EUD, men de skoler, som har indgået i analysen, dækker et bredt udsnit af forskellige erhvervsuddannelser inden for de tre overordnede retninger, Teknisk, Social og Sundhed samt Merkantil inden for Erhvervsuddannelserne.

Vi har indledt følgeforskningen, med et forstudie om entreprenørskab i uddannelsessammenhæng, og undersøgt om der er tidligere undersøgelser, der har belyst sammenhæng mellem lærernes pædagogiske og didaktiske praksis, elevernes lyst til uddannelse og deraf fastholdelse (Day, Larsen og Sørensen 2016). Vi har ligeledes undersøgt, hvilke lærings - og motivationsforståelser, der knytter sig til entreprenøriel praksis i uddannelseskontekster. Med afsæt i Fonden for entreprenørskabs forståelse af entreprenørskab, og den grundforståelse af entreprenørskab inspireret af den eksperimenterende tænkning (Hutters og Sørensen 2015), der er skrevet frem i vidensgrundlaget for udviklingsprojektet Fagligt Entreprenørskab, har vi foretaget en indkredsning af forskningsprojektets forståelse af motivation og læring i sammenhæng til entreprenørskab.

Analysen er indledt med beskrivelser af, hvordan de forskellige begreber som præsenteres i forskningsspørgsmålet skal forstås. De bagvedliggende teoretiske forståelserne, er blandt andet hentet fra forstudiet til analysen (Day, Larsen og Sørensen 2016)

\section{Om entreprenørskabsundervisning:}

Analysen tager afsæt i forståelsen om undervisning gennem entreprenørskab som er, når læring sker igennem deltagelse i et entreprenørielt forløb (Pittaway \& Edwards, 2012). Vi forstår undervisning gennem entreprenørskab som, at entreprenørskab kan blive implementeret $\mathrm{i}$ mange forskellige undervisningsforløb, og fokus er på læringsmetoder, og det at lære gennem en entreprenøriel proces. Undervisningsforløbets almindelige læringsmål kan opnås samtidigt med, at elever klædes på med handlingsorienterede kompetencer, samt evnen til at handle entreprenørielt og foretagsomt (Moberg 2014). 
Følgeforskningens forståelse af entreprenørskab og entreprenørskabsundervisning, hviler på den definition som Fonden for Entreprenørskab har skrevet frem, dvs.: Entreprenørskabsundervisning er "Indhold, metoder og aktiviteter, der understøtter udvikling af motivation, kompetence og erfaring, som gør det muligt at iværksætte, lede og deltage i værdiskabende processer" (Fonden for Entreprenørskab, 2016), og at entreprenørskabsundervisning adskiller sig fra andre tilstødende undervisningsformer ved at være problemorienteret, mulighedsorienteret, eksperimenterende, innovativ og samskabende (Lackéus, Lundqvist \& Williams-Middleton 2015). Flere af de deltagende lærere har anvendt eksperimenthjulet målrettet elever (Koch og Sørensen, 2017), som ramme for design af et undervisningsforløb omhandlende entreprenørskab, der forventes at understøtte ovenstående forståelse af entreprenørskabsundervisning (læs uddybende fra side 14)

\section{Om læring}

Analysens tilgang til læring bygger på en sociokulturel læringsteori. Denne læringstilgang er indkredset i sammenhæng til forstudiet for analysen (Day, Larsen og Sørensen 2016). Det er en læringstilgang, der ser læring, ikke kun som noget, der foregår i et samspil mellem den lærende og dennes omverden, men også som at selve læringsproduktet aflejres i konteksten - og ikke som egenskaber ved den lærende. Denne tilgang kan også ses som en interaktiv læringstilgang (Beck, 2014), og den er således modsat en mere individorienteret læringstilgang, hvor læring ses som tilegnelse af individuelle egenskaber, færdigheder - f.eks. en reaktiv læringstilgang (Se f.eks. Beck, 2014).

Den bagvedliggende læringsforståelse ser altså læring som situeret, grundlæggende social, distribueret, deltagelse i praksisfællesskaber, samt at læring erfares gennem praksisbaseret handling, og sker gennem en eksperimenterende tilgang (læs uddybende fra side 19).

\section{Om Motivation}

I forstudiet til analysen (Day, Larsen og Sørensen 2016) undersøger vi, hvad udvalgt forskning siger om, hvordan elevmotivation skabes i en læringskultur tillige med Fonden for Entreprenørskab forståelse af motivation. Nedenstående er de motivationsforståelser, som denne analyse lader sig inspirere af, for at kunne analyserer motivation i sammenhæng med undervisning gennem entreprenørskab 1) Betingelser for motivation, herunder at etablere inklusion, udvikle holdninger, udbygge meningsfuldhed og at udvikle kompetencer og 2) Motivationsorienteringer udlagt som vidensmotivation, præstationsmotivation, mestringsmotivation, relationsmotivation og involveringsmotivation (Pless, Katznelson, Hjort-Madsen, og Nielsen, 2015). (Læs uddybende fra side 20).

\section{Om elever, der har særlige udfordringer}

I forstudiet til analysen (Day, Larsen og Sørensen 2016) siges det opsamlende, at når særligt udfordrede elever, beskrives ved faglige, sociale og personlige udfordringer, så synes der at tegne sig det fælles træk, at det mere er elevens forventninger om mestring, end deres udfordrethed i sig selv (Day, Larsen og Sørensen 2016), der får betydning for, at eleven præsterer bedre. Den forskning, der ligger til grund for dette, bygger på betydningen om at fokusere på skolens læringsmiljø, og det er med det afsæt, vi undersøger hvordan udfordrede elever, kan profitere af entreprenørskabsundervisning i form af motivation og læring (læs uddybende fra side 22).

\section{Om Metode}

Empirien er generet ved at følge 18 undervisningseksperimenter. De anvendte dataindsamlingsmetoder er dokumentlæsning (eksperimentbeskrivelser), samt observationer under lærer- 
nes gennemførelse af undervisningseksperimenter i deres egen praksis. Der er foretaget individuelle interviews med lærere, og både individuelle, par og gruppeinterviews med elever på udvalgte skoler. Derudover er der blevet gennemført to læringscirkler (læs uddybende fra side 23).

\section{Om Analysen}

Analysen i den kvalitative følgeforskning, er foretaget på baggrund af observationer og interviews på udvalgte erhvervsskoler, og den er ikke repræsentativ. Den viser sammenhænge mellem den undervisning omhandlende entreprenørskab, som eleverne har deltaget $\mathrm{i}$, og deres motivation og læring, den siger også noget om, hvad det er ved den undervisning som de har deltaget i, der motiverer og skaber læring, og hvorfor den gør det. Til at undersøge, hvordan undervisning gennem entreprenørskab påvirker elevernes motivation og læring, har vi forholdt os til, om der er tegn på, at de didaktiske aktiviteter, som lærerne iværksætter, indikerer læring og motivation hos eleverne. Hvis det er tilfældet antager vi, at der er en sammenhæng mellem de undervisningsformer udtrykt som de didaktiske greb, som læreren iværksætter, samt elevens motivation og læring. Tegnene på læring og motivation, identificerer vi bl.a. ud fra vores teoretiske forståelser af motivation og læring.

Den empiribårne didaktiske del af analysen består af tre analytiske blik.

- Det første blik, er didaktiske billeder på, hvordan lærerne tilrettelægger deres entreprenørskabsundervisning, gennem didaktiske design inden for de fire entreprenørskabsdimensioner, med henblik på at udvikle elevernes entreprenørielle kompetencer.

- Analysens andet blik, er didaktiske billeder på elevernes deltagelsesmåder, hvor vi undersøger hvordan eleverne deltager i den entreprenørskabsundervisning, som er genereret gennem undervisningseksperimenter.

- Analysens sidste tredje blik, er 'særlig udfordrede elever'. Dette blik har vi fremstillet omkring tværgående didaktiske tematiseringer, som har åbnet sig under de første to blik og under selve analysen omkring de særlig udfordrede elever.

Fokus er altså på, hvordan den situerede brug af entreprenørskabsdidaktik organiserer undervisningen, og den kompetenceudvikling gennem motivation og læring, som det åbner for (læs uddybende fra side 25).

\section{Sammenfattende om resultater/fund $\mathrm{i}$ analysen}

Der er i den kvalitative adskillige eksempler på, at de deltagende elever klart har profiteret af at deltage i undervisningseksperimenter omhandlende entreprenørskab. Og både udfordrede og ikke-udfordrede elever, fået nye indsigter gennem deres deltagelse i undervisning omhandlende entreprenørskab. Dette ses illustreret i følgende citat fra en observationsnote, og efterfølgende elevinterview.

Eleverne på mureruddannelsen sidder ved hver deres computer, fordybet i eget projekt. Der er en stille og rolig stemning i lokalet, og det virker til, at alle eleverne arbejder engageret $i$ deres eget projekt. De har startet dagen med et kort fælles oplæg fra læreren og arbejder herefter på denne måde hele dagen - frem til kl. 15 kun afbrudt af en frokostpause på en halv time, hvorefter de hurtigt genoptager arbejdet. Stemningen dagen igennem er præget af arbejdsomhed, og iver efter at fordybe sig i eget projekt. Det ser ikke ud til, at de bruger tid på at gå ud på Facebook, eller lave andet end det fagrelevante i forhold til deres projekter (fra observationsnoter). Nogle af eleverne giver i interviews udtryk for, at de er glade for, at de har fået idéerne selv til, hvad de ville arbejde med. Som en af dem siger: "Man vælger helt frit selv, og det er det, jeg synes der er det fede ved det her". 
De innovative aspekter synes også at være værdifulde for eleverne. Det er personligt involverende for eleverne, når undervisningen har til hensigt at skabe værdi for andre, og eleverne arbejder med virkelige/autentiske problemstillinger:

Dette er illustreret med uddrag fra billede i nedenstående eksempel: Eleverne er i gang med et entreprenørskabsforløb, eleven går på SOSU GF1. Eleverne skal gennem aktioner skabe værdi for borgere, der har brug for hjælp.

Interviewer: Nu siger du, at du har lært noget, du har også følt noget, omkring hjemløse. Kan du prøve at sætte nogle ord på det?

Elev: Det giver så meget personligt, og så meget socialt. Altså, der er mange måder man kan blive pædagog på, f.eks. man kan tage gymnasievejen, hvor man bare læser en bog. Vi er i jo ude med mennesker. Vi snakker med rigtige mennesker. Vi gør det man elsker, alle elsker, hele klassen elsker, alle her på skolen elsker, nemlig mennesker. Og det kan man ikke bare læse $i$ en bog.

Om sammenholdet under eksperimentet siger eleven - "F.eks. så holder vi jo sammen, vi snakker sammen, og vi gør det her arrangement med at give kage, sammen. Vi gik alle sammen rundt og gav kage, og vi blev alle sammen påvirket på den her måde, fordi det var et emne, som vi ikke havde regnet med ville være så seriøst. Så vi blev også lidt chokerede over, at vi gjorde det, for det her er ikke bare en dukke, eller en eller anden fra klassen, det er ægte mennesker som ikke har det godt.

Analysen peger på, at processer, hvor eleverne arbejder sammen med øje for hinanden, har en særlig positiv betydning ved, at eleverne bruger hinandens ressourcer i gruppearbejde. Den mere kollaborative tilgang til samarbejde, hvor eleverne samarbejder om den samme opgave, synes at udgøre en betydning ved at være lærings- og motivationsfremmende, hvilket ovenstående eksempel også illustrerer.

Et resultat I analysen vedr. de udfordrede elever er, at de gennem deres deltagelse i undervisningseksperimenter omhandlende entreprenørskab, i overbevisende grad engagerer sig, deltager aktivt, går aktivt ind i processen med at forbedre undervejs, når de møder en didaktik, der er karakteriseret ved:

Bevægelser fra usikker til mere sikker.

Inklusion i grupper i forbindelse med samarbejde/samskabelse.

Succeser giver selvtillid og lyst til mere.

Lærere, der opmuntrer og ikke dømmer.

Inddragelse af elevens erfaringer, som afsæt for idéudvikling med mere.

At stemningen i forbindelse med entreprenørskabsundervisning er åben, munter og fri.

Den indsamlede empiri viser betydningen af en didaktik, der tilsigter at fremme entreprenørielle kompetencer hos elever med dårlige skoleerfaringer både forstået som deres relationer til andre elever og deres forhold til læring. Gennemgående er det, som har haft betydning været, at læreren afgiver noget af styringen af undervisningen til eleverne selv, ved at styringen flyttes fra læreren, som den der har monopol på viden og svar til en anderledes styring med fokus på, at læreren i højere grad faciliterer processer, orkestrerer og stiller spørgsmål. Materialet peger på, betydningen af en didaktik, der åbner for læringsfremmende interaktion mellem eleven og elevens omverden. 
Det interessante er, at det ser altså ud til at mindre, eller måske mere præcist udtrykt anderledes struktur og rammesætning, samt mindre klassisk lærerstyring og mere proces - og organisationsstyring synes, at berige og fremme motivation og læring.

Dette var især aspekter, der blev trukket frem i tredje blik, under analyse af elever med særlige udfordringer. Dette udtrykker en elev således:

En elev, en dreng fortæller om måden de arbejder på i klassen, at "der er meget selvstændigt arbejde og der er ikke en normal skoleform som man kender [fra tidligere]". Han fortæller, at han altid har været en outsider i sine tidligere skoler, og lærerne har ikke troet på, at han kunne noget, og at han har ikke haft mange venner i klassen. "Nu skal jeg selv arbejde i klassen, og man skal selv finde på ideer, producerer denne her ting, og det giver så meget til en selv, og det giver en indre glæde. Især $i$ slutningen af ugen. Man blev glad. Altså i løbet af ugen blev man presset, fordi der var pres på for at nå det, så der sidst på ugen, der løsnede vi jo op, for nu var vi jo færdige, og nu skulle vi jo bare vise vores spil frem, og vise hvad vi havde lavet. Og så endte vi med at stå stolt oppe med vores produkt, som vi var meget tilfreds med". (elevinterview EUD Social og sundhed)

De didaktiske greb, som udfordrede elever selv fremhæver som engagerende og fremmende for deltagelse kan karakteriseres ved:

- Åbenhed om indhold og form i undervisning - forstået som mere indflydelse til eleverne ift. bestemmelse af, hvad der præcist sker i undervisningen. Dvs. mindre kontrol fra læreren ift. hvordan undervisningen gennemføres.

- Lærerrollen, som bevidst trækker sig i baggrunden for at give plads til elevens selvigangsatte aktiviteter, eller som bevidst er i øjenhøjde med eleverne, og forholder sig undrende, undersøgende og som medskaber i processen for at give lærerstøtte undervejs.

- Elevrolle, som selvstændig og som vil tage ansvar og som en elev, der aktivt vil og kan tage del i egen læring og som stræber efter at 'blive til noget' - og gerne blive til noget særligt' yderligere stræben efter at indgå positivt og konstruktivt i læreprocesser - såvel alene som i sociale sammenhænge.

- Gruppearbejde, der arbejder efter kollaborative principper, hvor eleverne har fælles ansvar og træffe de vigtigste beslutninger sammen og alle trækker på samme hammel - trods individuelle forskelle.

- Inklusion gennem samarbejder, hvor eleverne oplever anerkendelse og aktiv deltagelse af alle. Dermed er samarbejdet med til at minimere sociale og faglige udfordringer.

At undervisning gennem entreprenørskab, har den indflydelse på elevernes oplevelse af motivation, læring og lyst til deltagelse i uddannelse, kan godt opfattes at stå i modsætning til de gængse anbefalinger til frafraldstruede elever, om vigtigheden af faste rammer, som andet dansk forskning har underbygget (se fx Marselisborg Praksisvidencenter (2011) samt Pless et al (2015).

Den anderledes styring -som ydre struktur, her udlagt som timer, tid, fag, klasse, faste pladser, fast indhold og form, direkte lærerstyring skal nedtones, i stedet skal der tilstræbes mere indre struktur forstået som synlige processer for eleverne, variation i rum og roller i sammenhæng til opgaven, rammesætning af læring, tilpasse forstyrrelser, kollaborative arbejdsformer, lærerrolle i øjenhøjde med eleverne. Analysen peger på, at indre struktur synes at berige og fremme elevernes motivation, læring og lyst til deltagelse. Det er især aspekter, der blev trukket frem i analysen af elever med særlige udfordringer.

De didaktiske greb i de entreprenørielle forløb, er blevet analyseret med henblik på, hvad og hvordan de styrker læring og motivation. Vi har analyseret, hvilke forhold der i sammenhæng til 
anvendelsen af de didaktiske greb, har haft særlig betydning for læring og motivation, og dermed udvikling af elevens entreprenørielle kompetencer. I analysen har vi fundet fem tværgående didaktiske forhold, som med afsæt i bl.a. ovenstående og den efterfølgende tekst, kan sammenfattes om fem didaktiske forhold som er vigtige at være opmærksomme på, hvis entreprenørskabsundervisningen skal fremme læring og motivation, med fokus på elevernes lyst til deltagelse:

- Undervisningsformer, metoder og indhold, der åbner for aktiv deltagelse

- Samarbejde om opgaven og relationer i sammenhæng dertil

- Lærerroller i øjenhøjde, der faciliterer og skubber

- Praksislæring og samspil med omverdenen

- Mestring gennem aktiv handlen og medbestemmelse

De eksempler, hvor eleverne særligt synes at blive motiverede, og er i læring er undervisning, hvor eleverne arbejder problemorienteret med afsæt i udfordringer og behov, mulighedsorienteret f.eks. åbne opgaver - uden fast indhold, mål og tid, eksperimenterende f.eks. når eleverne undersøger og finder på nyt. Disse undervisningsforløb er karakteriseret ved en anderledes grad af struktur, rammesætning og lærerstyring, end den som eleverne traditionelt set har erfaringer med, og det fremhæver de som betydningsfuldt.

Sammenhængen mellem undervisningen gennem entreprenørskab, når den udtrykkes gennem den sociokulturelle læringstilgang, og elevens læring, udtrykt gennem elevens udvikling af entreprenørielle kompetencer, er karakteriseret ved tydelige undervisningsformer, hvor læreren giver plads til elevernes idéer, faglige indspark, og planlægning af tid og forløb, og selv træder enten i baggrunden, eller gennem sparring er i øjenhøjde med eleven. Hvor eleven får mulighed for at deltage i, og bruge ressourcer i praksisfællesskabet (de andre elever på holdet) ikke blot fremmer læring, men også udvider og forstærker læring. Endvidere viser analysen, hvorledes undervisningseksperimenterne omhandlende entreprenørskab i deres didaktiske opbygning, og lærerens valg af anden lærerrolle, eller ligefrem lærerposition, synes at gøre motivation og læring gensidigt forstærkende. Et andet gennemgående træk er, at såvel arbejdet med dimensionerne (kompetencer for entreprenørskab), samt ændrede deltagelsesmåder i retning af, at eleven får muligheder for at være medskaber, og selv designe indhold til entreprenørielle forløb, fra udfordring til produkt, og tage medansvar for læreprocesser, netop synes at fremme motivation og læring.

Analysen peger på, at det har stor betydning for eleverne og i særdeleshed elever med udfordringer, at de tror på, at de kan magte de opgaver, de arbejder med i undervisningen. Det er vigtigt for deres engagement, at de tror på, at de kan komme til at mestre opgaverne, og at de ikke oplever sig bremset af frygt for, at deres evner ikke slår til. Når de oplever succes med en opgave, giver det dem blod på tanden i forhold til, at kaste sig ud i den næste opgave.

Et gennemgående træk i analysen er, at elevernes engagement, ofte viser sig i forbindelse med deres muligheder for at arbejde aktivt med undervisningsaktiviteterne. Deres selvvirksomhed og foretagsomhed ser ud til at hænge sammen med, at de får mulighed for at arbejde med opgaver, som giver mening for dem, og som de selv har været medbestemmende omkring.

Samlet set er der adskillige eksempler på, at den gennemførte undervisning initierer motivation og læring. Det er særligt bemærkelsesværdigt, at det er et gennemgående træk, at når eleverne får mulighed for at arbejde med læring ift. noget, der er personligt meningsfuldt, involverer handling, samarbejde med andre elever, kreativitet og autentiske opgaver der værdsættes i omverdenen, så øges intensitet og engagement. 
Den entreprenørskabsundervisning, som de deltagende lærere har udviklet gennem deres undervisningseksperimenter er karakteriseret ved at:

- Eleverne tager medansvar for læring og viser ejerskab over læreprocessen. F.eks. er der flere eksempler, hvor eleverne tydeligt fortæller, hvad der virker understøttende for deres læreproces. Hvordan elev-lærerrelationen skal være. Hvordan relationer til de andre elever skal være. Og hvordan opgaverne bedst stilles, så de virker motiverende.

- Eksperimenterne udvider læringsindholdet. Med det menes, at eleverne ikke bare lærer mere eller er mere motiverede men, at de lærer anderledes og herigennem ser ud til at have et kvalitativt andet læringsudbytte. F.eks. viser analysen, at flere elever, der begejstret og ivrigt fortæller om deres opgaver under uddannelsen og deres uddannelse i øvrigt. Dette er ikke skole, siger de. Og de giver udtryk for, at de slet ikke 'mærker læringen komme ind' og der er selvforglemmende stunder, der kan karakteriseres som det at være i flow.

- Eleverne overkommer udfordringer. Der er flere eksempler på elever, der arbejder ihærdigt med at overstige og komme igennem svære opgaver - de erfarer at lære med møje (Hermansen, 2012).

- Fællesskaber om opgaver beriger elevernes lærerprocesser. Der er flere eksempler på, hvorledes fællesskabet mellem eleverne er stærkt berigende for læreprocessen, ikke blot til gensidig inspiration, men selve det at deltage og inkluderes i fællesskabet synes at være særligt styrkende.

- Elever trives med lærerrelationer i øjenhøjde. Eksempler viser, at eleverne klart foretrækker lærerrelationer, hvor læreren i højere grad står ved siden af eleven (i øjenhøjde) og ofte også bagved (støttende) mere end foran (doserende). Eleven ønsker at indgå i mere ligeværdige relationer med læreren og viser også tydeligt, at de kan og vil bruge lærerens ekspertise - især hvis ekspertisen 'gives', når eleven er opsøgende.

- Motivation og læring kan være gensidigt forstærkende. Motivation er ikke blot forudsætning for læring. Læring kan også berige motivationen. Vi så flere eksempler på, hvorledes læreprocesserne synes at styrke den videre motivation.

- Motivation kan være et resultat af undervisningen og beriges, når eleven mødes på sine motivationsorienteringer og undervisningen giver mulighed for, at eleven kan følge disse orienteringer, f.eks. ved, at eleven kan arbejde med opgaver, der er personligt involverende og meningsfulde.

\section{Følgeforskningens design}

\section{Forskningsspørgsmål i den kvalitative del af følgeforsk- ningen}

Udgangspunktet for den kvalitative del af følgeforskning, er undersøgelse af elevernes motivation og læring, i sammenhæng med lærernes didaktiske design og i forhold til at fremme fagligt entreprenørskab i undervisningen. På baggrund heraf, er forskningsspørgsmålet som følger:

Hvordan kan den entreprenørskabsundervisning, som genereres i udviklingsprojektet, påvirke elevers læring, motivation og lyst til at deltage i uddannelse. Herunder hvordan elever, der har særlige udfordringer, kan profitere af denne form for undervisning.

Som del af den videre beskrivelse af analysens design, vil vi kort udfolde de centrale begreber i forskningsspørgsmålene, med henblik på, at tydeliggøre forforståelse af sammenhæng mellem 
undervisning, motivation og læring. Dernæst vil vi beskrive analysens genstandsfelt, -metode og analysens opbygning.

Svaret på om eleverne får lyst til at deltage i uddannelse, er indlejret i analysen om motivation og læring, da vi som udgangspunkt vil tolke deltagelse, som et tegn på motivation og læring.

Mere herom senere.

Det giver os to undersøgelsesspørgsmål, som den videre analyse vil forsøge at svare på:

- Hvordan kan den entreprenørskabsundervisning, som genereres i udviklingsprojektet, påvirke elevers motivation og læring?

- Herunder hvordan elever, der har særlige udfordringer, kan profitere af denne form for undervisning?

\section{Udfoldelse af begreber i undersøgelsesspørgsmålene}

\section{Første undersøgelsesspørgsmål}

Med 'hvordan den entreprenørskabsundervisning, som genereres i udviklingsprojektet' forstår vi:

Analysen baserer sig på de undervisningseksperimenter i regi af entreprenørskabsundervisning - som de deltagende lærere afprøver, som led i deres efteruddannelse, og hvordan de undervisningseksperimenter omkring entreprenørskab virker i samspil med elever. Det er altså lærerens didaktiske overvejelser, og dertilhørende undervisningspraksis, der er i fokus, jf. nedenfor.

Lærernes undervisningseksperimenter, er eksemplariske bud på hvordan entreprenørskabsundervisning under udvikling kan tage sig ud. De undervisningseksperimenter, der undersøges i følgeforskningen, er lærerens bedste bud på at skabe entreprenørskabsundervisning, der for dem er relevant og meningsfuld i relation til den givne kontekst, uddannelse og elevmålgruppe, hvor eksperimenterne konkret gennemføres.

I det følgende vil vi omtale de entreprenørskabsforløb, som lærerne har udviklet og eleverne deltaget $\mathrm{i}$, som undervisningseksperimenter omhandlende entreprenørskab. Vi vil afslutningsvis drøfte sammenhæng mellem didaktiske greb (fund i empirien), og definitioner af entreprenørskabsundervisning og på den baggrund reflektere, hvilken påvirkning entreprenørskabsundervisning kan have på elevers motivation og læring, herunder elever med særlige udfordringer. Refleksionen og sammenfattende pointer vil åbne op for afrundende perspektiver over betydningen af didaktiske greb, og forhold i sammenhæng til i entreprenørskabsundervisning, som det er væsentligt at trække frem og styrke fremadrettet.

\section{Analysens forståelse af entreprenørskabsundervisning}

Analysen tager afsæt i Fonden for Entreprenørskabs forståelse af, hvilke forhold, der rammesætter entreprenørskabsundervisningen.

Ifølge Fonden for Entreprenørskab (Fonden for Entreprenørskab, 2015, s. 9), er entreprenørskabsundervisning i form og indhold en undervisning som:

Understøtter udviklingen af elever / studerendes entreprenørielle viden og færdigheder. Understøtter udviklingen af elever / studerendes personlige og emotionelle ressourcer. Giver elever / studerende erfaringer med at anvende viden, færdigheder og personlige ressourcer i værdiskabende processer

Giver eleverne mulighed for at reflektere og forholde sig kritisk og etisk til værdiskabelse.

Den ovenstående forståelse af entreprenørskabsundervisning hviler på Fonden for Entreprenørskabs definition af entreprenørskab: 
"Entreprenørskab er, når der bliver handlet på muligheder og gode ideer, og disse bliver omsat til værdi for andre. Den værdi, der skabes, kan være af økonomisk, social eller kulturel art" (Fonden for Entreprenørskab, 2011).

Det er en forholdsvis bred definition, som lægger mere op til udvikling af et entreprenant mindset, end mere snævre færdigheder indenfor iværksætteri. Med afsæt i denne forståelse af entreprenørskab, definerer Fonden for Entreprenørskab entreprenørskabsundervisning således:

"Indhold, metoder og aktiviteter, der understotter udvikling af motivation, kompetence og erfaring, som gør det muligt at iværksætte, lede og deltage i værdiskabende processer" (Fonden for Entreprenørskab, 2016).

Indholdsmæssigt kan entreprenørskabsundervisning kendetegnes ved, at indeholde fagligt og entreprenørielt indhold, samspil med omverdenen og drivkraft, her udlagt som motivation eller mental energi (Fonden for Entreprenørskab, 2016, s.25). Entreprenørskabsundervisning kan udgøre en meget bred pallet, af uddannelses- og læringsmæssige mål og strategier.

Typisk er der tre kategorier, som forskere inden for feltet plejer at bruge, til at kategorisere entreprenørskabsundervisning. Der er undervisning om, for og gennem entreprenørskab (Hannon, 2005). Undervisning om entreprenørskab er typisk teoretisk. Undervisning om entreprenørskab har som formål at klæde elever/studerende på med kundskab og forståelse om entreprenørskab samt entreprenørskabsforskning. Undervisning for entreprenørskab, har som formål at forberede elever og studerende på en karriere, som iværksættere eller entreprenører. I denne undervisning, er der typisk fokus på både teoretiske kundskaber om entreprenørskab, og praktiske handlingsorienterede kompetencer. Undervisning gennem entreprenørskab er, når læring sker ved, at elever og studerende deltager $i$ et entreprenørielt forløb. Fonden for entreprenørskab opererer også med en fjerde tilgang, hvor entreprenørskab er udlagt som indlejret (embedded) i undervisning inspireret af Pittaway \& Edwards. I denne analyse skelner vi ikke mellem undervisning gennem entreprenørskab og entreprenørskab indlejret $\mathrm{i}$ undervisning, men forstår undervisning gennem entreprenørskab som, at entreprenørskab kan blive implementeret i mange forskellige undervisningsforløb, og fokus er på læringsmetoder og det at lære gennem en entreprenøriel proces. Undervisningsforløbets almindelige læringsmål kan opnås samtidigt med, at elever klædes på med handlingsorienterede kompetencer, samt evnen til at handle entreprenørielt og foretagsomt.

Entreprenørskabsundervisning bør ifølge Fonden for Entreprenørskab fokusere på, at udvikle de studerendes motivation-, kompetence- og erfaringsudvikling i forhold til, at kunne skabe økonomisk, social eller kulturel værdi, hvilket ifølge Fonden for Entreprenørskab bør ske gennem en handlingstilrettet tilgang, hvor de studerende kan danne sig egen forståelse og referenceramme af entreprenørskab. Tidligere har entreprenørskabsundervisning, i lighed med undervisning i innovation, i høj grad baseret sig på specifikke læreres egen erfaring, relationer og initiativ. Dette kan gøre det vanskeligt, at arbejde med entreprenørskab på en mere målrettet og didaktisk velfunderet måde på erhvervsskoler. Fonden for Entreprenørskab har i denne sammenhæng udviklet en taksonomi (Fonden for Entreprenørskab, 2016, s.15 - 20), der sætter elevers indfrielse af læringsmål ind i en struktureret ramme, som undervisere kan bruge i tilrettelæggelse af undervisningen i netop entreprenørskab. Denne taksonomi formulerer formål for entreprenørskabsundervisning som:

- At give den enkelte mulighed for, og redskaber til, at forme sit eget liv.

- At uddanne engagerede og ansvarstagende medborgere.

- At udvikle viden og ambitioner om at etablere virksomheder og arbejdspladser.

- At øge kreativitet og innovation i eksisterende organisationer.

- At skabe bæredygtig vækst og udvikling, kulturelt, socialt og økonomisk. 
Ovenstående formål giver inspiration til operationelle læringsmål for erhvervsskolelære, til at arbejde med entreprenørskab i deres almindelige praksis.

I det følgende, vil vi udfolde de mere overordnede elementer i den forståelse af entreprenørskabs-undervisning, som følgeforskningen tager udgangspunkt i.

Fonden for Entreprenørskab fremhæver, at entreprenørielle undervisningsforløb skal understøtte dannelsen af erfaringer, og ikke som mange udlægger anvendelsen af erfaringsbegrebet, som at tage udgangspunkt i elevens erfaringer (Fonden for Entreprenørskab, 2016). Erfaringer danner dispositionsmuligheder for fremtidig handlen, tænkning og refleksion.

Til denne forståelse af entreprenørskabsundervisning har vi i forstudiet (Day, Larsen og Sørensen, 2016) fremhævet Tinne Geigers tilgang, hvor hun understøtter betydningen af erfaring gennem afprøvning, eller eksperimenteren i sin artikel How to create innovative mindsets fra 2015. Hun tillægger læringslandskaberne, og måden eleverne deltager i disse, stor betydning. For at skabe innovativ og entreprenant tænkning er det vigtigt, at eleverne kommer ud af klasserummet, og engagerer sig gennem eksperimenterende læring i omgivelser, hvor alle lærer af hinanden (Geiger, 2015). I forstudiet peger vi på, at både Dewey og Vygotskij fremhæver, at elevernes håndtering af fejl gennem eksperimentbaseret læring, er omdrejningspunkt for erfaring, og at undervisere har som opgave, at facilitere den læring, og sætte noget på spil i et læringsrum, etableret ud fra deltagelse i aktiviteter omkring et fællesskab, med mulighed for at erfare gennem afprøvning. Brinkmann fremhæver et citat fra en Deweytekst fra 1902, s. 18 "Intet kan udvikles af intet". Med det menes, at intet menneske kan skabe uden indblanding (Brinkmann, 2007).

Under efteruddannelsen, er der blevet tilpasset et eksperimenthjul til eleveksperimenter benævnt til anledningen "entreprenørskabshjulet" (Koch og Sørensen, 2017). Dette eksperimenthjul målrettet elever er anvendt i sammenhæng med udviklingen af de deltagende læreres entreprenørskabsundervisning. Formålet med entreprenørskabshjulet som eksperimenthjul målrettet elever (se figur nedenfor), er, at det kan rammesætte elevernes læring, og understøtte lærernes pædagogiske og didaktiske designs for undervisning, hvor deres elever forventes at kunne udvikle entreprenørielle kompetencer.

Forløbsmodellen til lærerens arbejde med eleveksperimenter danner altså ramme for at afprøve eksperimenterede læringsflow for eleverne i sammenhæng til undervisningen. Intentionen med entreprenørskabshjulet - et eksperimenthjul målrettet elever er, at eleverne får mulighed for at arbejde eksperimenterende og udforskende, lige fra afdækning af behov/udfordring/muligheder, til formulering af forestillinger om den endelige iværksættelse i form af værdiskabelse i bred forstand.

Entreprenørskabsdimensionen ekspliciteres gennem de seks læringsfaser, der er i eksperimenthjulet målrettet elever. Her vægtes i særdeleshed det udforskende og eksplorative arbejde, der handler om at undersøge, hvilke behov der er for fornyelse, at designe prototyper på nye værditilførende praksisser eller produkter, at iværksætte aktiviteter i forbindelse med elevernes eksperimenter, at inddrage brugerne, at samle viden, at omsætte viden gennem prototyping, og udarbejde koncepter til implementering og forankring.

I den eksperimentbaserede tilgang til læring er handlings - og værdiskabelsesdimensionen et væsentligt element i alle seks faser. Lærernes didaktisering af eksperimentbaseret læring $(E B L)$, i denne analyse i sammenhæng til entreprenørskabsundervisning, hvor eleverne arbejder med eksperimenter, forventes at understøtte både udviklingen af et entreprenant mindset hos eleverne, og at give dem de kompetencemæssige forudsætninger, for at kunne påvirke og få indflydelse på udviklingen af deres kommende faglighed. 


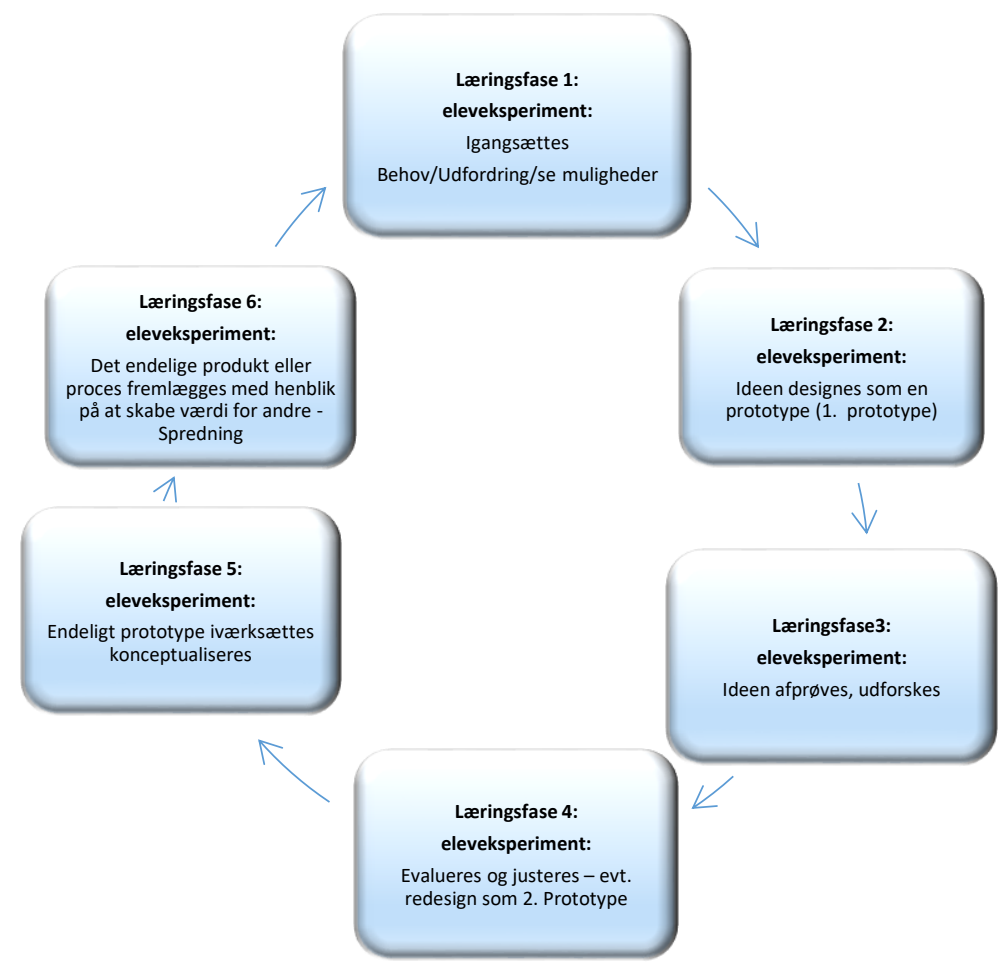

Figur. Entreprenørskabshjulet - et eksperimenthjulet målrettet elever. Model for erhvervsskoleelevernes arbejde med eksperimentbaseret læring. (Koch og Sørensen, 2017)

Ovenstående forståelse af entreprenørskabsundervisning er central i analysen, fordi det er en bærende forståelse af rammerne for den præsentation af entreprenørskabsundervisning, som de studerende bliver introduceret for i efteruddannelsen Fagligt Entreprenørskab.

De perspektiver, der er nævnt i ovenstående, understøtter den pædagogiske praksis, som rammesætter entreprenørskabsundervisningen, i regi af Fonden for Entreprenørskabs forståelse af entreprenørskabsundervisning. Læreren som facilitator tillægges stor betydning for det læringsmiljø, hvori læringen skal indgå. De erfaringer, som eleven danner, skal udfordres i sammenhæng med den situation, som læringen foregår i, og til målet. Fonden for Entreprenørskab fremhæver betydningen af feedback, som et væsentligt parameter for, hvor meget eleverne lærer (Fonden for Entreprenørskab, 2015, s. 29).

Et forskerteam undersøger forskelle på entreprenørskabsundervisning, og andre tilstødende undervisningsformer (Lackéus, Lundqvist \& Williams-Middleton, 2015). Heraf fremgår det, at entreprenørskabsundervisning er:

- Problemorienteret: Problemer som afsæt for idéer og løsninger

- Mulighedsorienteret: Mulighedsorienterede processuelle forløb, dvs. hvor mål ikke er klart afgrænsede/definerede

- Eksperimenterende: Eksperimenterende og undersøgende tilgang, hvor det er naturligt at mislykkes og prøve igen

- Innovativ: At være innovativ og nyskabende med det formål at skabe værdi for andre

- Samskabende: Samskabende processer, hvor eleverne samarbejder med hinanden, om at løse praksisnære og autentiske opgaver. 
Det skal dog fremhæves, at selvom erhvervsskolelærerne gennem deres deltagelse på udviklingsprojektets diplommodul "Fagligt Entreprenørskab, har erhvervet sig viden og gjort sig erfaringer, som de har omsat i egne undervisningseksperimenter omhandlende entreprenørskab i en lokal kontekst - altså ude på de skoler, hvor de arbejder til daglig, så skal læring i projektet, ikke forstås som en lineær proces, hvor studerende (i dette tilfælde lærerne på diplommodulet) ureflekteret overtager de begreber, og den forståelse af entreprenørskab, som lægges frem på diplommodulet. I stedet tilegner lærerne sig modulets begreber og forståelse, i forlængelse af deres egne subjektive erfaringer som lærere og den lokale kontekst, de arbejder i (Jank \& Meyer, 2006).

Videre med første undersøgelsesspørgsmål forstår vi:

Hvordan kan den entreprenørskabsundervisning, som genereres i udviklingsprojektet, påvirke elevers motivation og læring?

\section{Med 'påvirke' forstår vi}

I analysen er vi ikke optaget af at vurdere i hvilket omfang, eleverne motiveres eller der finder læring sted, ej heller en afklaring af motivationens eller læringens beskaffenhed/kvalitet. I analysen er vi derimod optaget af at sige noget om, hvordan undervisningseksperimenterne omkring entreprenørskab faciliterer elevernes motivation og læring ift. den pågældende erhvervsuddannelse, de er i gang med. Det er vigtigt at understrege, at vi med 'påvirke' ikke henviser til en reaktiv læringsforståelse, men en læringsforståelse, der baserer sig på et interaktivt afsæt - mere herom senere i læringsafsnittet.

\section{Med 'motivation og læring' forstår vi}

Dette er de to centrale begreber i forskningsspørgsmålet. Disse er udfoldet i forstudiet til projektet (Day, Larsen og Sørensen 2016). Kort vil vi her opsummere centrale elementer af forståelsesrammen.

Følgeforskningen bygger på en antagelse om entreprenørskabsundervisning, som undervisning, der motiverer til handling og derigennem læring samt samtidig giver unge med særlige udfordringer mod på deltagelse i undervisningen og lyst til foretagsomhed (Greve \& Kirketerp, 2011).

I forstudiet er sat en lærings - og motivationsteoretisk ramme op. Denne ramme baserer sig på den forståelse af motivation og læring, som vi i forstudiet skriver er indlejret i Fonden for Entreprenørskabs forståelse, samt en afgrænsning af entreprenørskabsundervisning, og det at agere entreprenant (Fonden for Entreprenørskab, 2015, s. 20-28). Det antages, at den entreprenante tilgang - som udfoldet v. Fonden for Entreprenørskab, og den deri indlejrede lærings- og motivationsforståelse - vil understøtte elevernes læreproces. Nedenfor beskrives kort denne lærings- og motivationsforståelse.

\section{Analysens læringsforståelse med afsæt i Fonden for Entreprenørskabs entreprenør- skabstilgang}

Vi har i forstudiet identificeret sociokulturelle teoriperspektiver på læring i Fonden for Entreprenørskabs beskrivelse af entreprenørskab, dog ikke i en rendyrket form (Day, Larsen og Sørensen 2016).

Det sociokulturelle bygger på en konstruktivistisk anskuelse, hvor det helt afgørende er, at viden bliver konstrueret gennem interaktion i en kontekst, og altså ikke overvejende som individuelle processer (Dysthe, 2001; Lave \& Wenger, 2003; Wenger, 2004). Interaktion og samarbejde bliver anskuet som helt centralt for læring. Det, at kunne noget betragtes i sociokulturel læringsteori som relateret til praksisfællesskaber, og individets evne til at deltage i sådanne (Lave \& Wenger, 2003; Wenger, 2004). Olga Dysthe (2001) fremstiller seks forhold, der karakteriserer sociokulturelt syn på læring: 
Læring er situeret

Læring er grundlæggende social

Læring er distribueret

Læring er medieret

Læring er deltagelse i praksisfællesskaber

Sproget er centralt i læringsprocesser

Handlings - og erfaringsgrundlaget for læring er udtrykt i flere læringsteoretiske forståelser. I den pragmatiske forståelse udtrykker Dewey det som, at læring grundlæggende handler om deltagelse (Brinkmann, 2007). I pragmatismen fremhæves synligheden, af et læringslandskabs indhold og formål, samt adgang for deltagelse som særlig vigtig for motivation til læring. Dewey mener, at aktivitet er helt centralt for læring (Brinkmann, 2007). Handleperspektivet - at gøre noget, er meget eksplicit i entreprenørielle kompetencer - at være foretagsom, at have mulighed for at udrette noget. Dewey mener, at mennesket som aktivt handlende væsen per definition er drevet til at skabe mening og sammenhæng i deres erfaringer. Han ser ingen barrierer mellem menneskets erfaringer og fagindholdet for så vidt, fagene og videnskaberne er udviklet, som svar på virkelige problemstillinger (Brinkmann, 2007).

Denne sammenhæng mellem fag og erfaring bygger på, at der i entreprenørskabsundervisning er indlejret et omverdens perspektiv, hvorigennem konkrete fag sættes i sammenhæng til relevans og anvendelighed (Fonden for Entreprenørskab, 2016). Dewey fremhæver, at når mennesket støder ind i problemer, vil det undersøge situationen og gennem eksperimenter få erfaring, der øger læring (Brinkmann, 2007). Netop erfaring gennem fejl og succeser, og handling gennem eksperimenter og den eksperimentbaserede læring (Koch og Sørensen 2017), er helt central i den læringsforståelse, som der er lagt op til i entreprenørskabsundervisning i de erhvervsrettede uddannelser. Analysens forståelsen af læring finder også inspiration i praksisbaseret læring (Hersom 2017).

Fonden taler særligt for, at der skal udvikles et entreprenant mindset, hvilket skal forstås som udvikling af kompetencer for entreprenørskab - mere end egentlige - og afgrænsede - færdigheder i entreprenørskab. Begrebet Entreprenant mindset tager afsæt i følgende forståelser; motivation, kompetence og erfaring, som gør det muligt at iværksætte, lede og deltage i værdiskabende processer (Fonden for Entreprenørskab, 2013). Ovenstående forståelse bygger på Knud Illeris forståelse: Motivation, kompetencer og erfaringer er baseret på såvel viden og færdigheder som på mere subjektive dispositioner, betydninger og potentialer relateret til mulige handlingsområder i usikre situationer (Illeris, 2013).

\section{Analysens motivationsforståelse med afsæt i Fonden for Entreprenørskabs entreprenør- skabstilgang}

Vi har i forstudiet (Day, Larsen og Sørensen, 2016) indkredset analysens forståelse af motivation til brug for analysen.

Fonden for Entreprenørskab's tænkning om motivation (fremlagt i Taksonomi i Entreprenørskabsuddannelse, 2015 s.28) bygger på forskning, som har vist, "at undervisning, der skaber engagement og studiemotivation typisk fokuserer på autentiske og praktisk rettede opgaver, som udfordrer de studerendes kreativitet og problemløsningsevner, samt omfatter gruppearbejde og giver plads til forskellige talenter" (Newman 1991 i Rasmussen, Moberg, og Revsbech, 2015). Endvidere nævnes (Wentzel \& Brophy, 2013) som finder, at elevernes "engagement $i$ læreprocessen" skabes ved at de "føler ejerskab og ansvar for opgaver og læreproces, samt at disse opgaver tilbyder variation, og at de studerende er med til at udføre alle aktiviteter fra idé til resultat"; "samt hvis de studerende må arbejde med ting der interesserer dem, helst ting de er emotionelt optagede af" (Newman 1991 i Rasmussen et al. 2015). Fonden for Entreprenørskab (Taksonomi i entreprenørskabsuddannelse 2015/2016) antager på den baggrund, at undervisning, som retter sig mod nedenstående faktorer, fremmer motivation ved at: 
- Fokusere på varierede, samt autentiske og praktisk rettede opgaver, som er meningsfulde, udfordrende og skaber værdi for andre

- Udfordre elevernes kreativitet og problemløsningsevner, og give plads til forskellige talenter

- Omfatte gruppearbejde

- Give eleverne ejerskab, ansvar for opgaver og læreproces

- Give eleverne mulighed for at udføre alle aktiviteter fra idé til resultat

- Arbejde med ting der interesserer dem, helst ting de er emotionelt optagede af

- Gøre det tydeligt hvordan resultaterne skal bruges, og hvilken værdi dette skaber

Vi har valgt yderligere, at tage afsæt i tre forskningstilgange i sammenhæng til motivation., Dels fordi de motivationsforståelser understøtter den forskning, som Fonden for entreprenørskab har lagt til grund for deres motivationsforståelse, og dels fordi de understøtter den måde vi vil fremanalysere sammenhænge, mellem de undervisningseksperimenter i entreprenørskab, som vi følger, og elevernes tegn på motivation i det empiriske studie.

For det første, at motivation øges, når eleverne oplever, at læring giver mening. Ifølge Knud Illeris sker dette, når det lykkes at knytte undervisning til noget, som eleverne "har en interesse i, kan engagere sig i, og kan finde sig selv i. Det afgørende er, at det er noget, eleverne kan forbinde med deres aktuelle situation, og deres fremtidsforestillinger" (Illeris i Sørensen, Katznelson, og Juul. 2013, s. 60).

Herudover trækker vi især på to kilder (Wahlgren et al., 2009; Pless et al., 2015), som beskæftiger sig med sammenhængen mellem motivation og læring.

I et litteraturstudie udarbejdet af Wahlgren et al. hævdes der, at motivation er kontekstbestemt og udvikles i komplekse samspil mellem forskellige faktorer (se forstudie side 13)

I Unges motivation i udskoling (Pless et al., 2015) argumenterer forfatterne for, at motivation ikke skal forstås "som en forudsætning for, at de unge kan lære noget i skolen, men snarere et resultat af det, der foregår i skolen" (Pless et al., 2015, s. 12). Ifølge denne tænkning skal motivationsbegrebet forstås som differentieret, kontekstuelt og kontingent (Pless et al., 2015, s. 30; jf. Illeris). Pless et al forstår Motivation som noget, der skabes i et samspil mellem 2 gensidigt forbundne kræfter: Subjektive og kulturelle. Motivation skabes altså i mødet mellem det, som giver mening for eleverne og den skole- og den klasserumskultur, de agerer i forhold til. På den subjektive side er forfatterne optagede af elevernes erfaringer med fokus på, "hvordan eleverne udvikler modet og viljen til at give sig i kast med læringsopgaver" (Skaalvik 2007 i Pless et al. 2015:32). Heri ligger koblinger til self-efficacy, hvor begge har som omdrejningspunkt, at elevernes tro på, at de kan mestre en opgave er afgørende. Paraplybegrebet motivationsorienteringer (Pless et al. 2015) samler fem forskellige motivationsorienteringer udlagt som vidensmotivation, præstationsmotivation, mestringsmotivation, relationsmotivation og involveringsmotivation. Motivationsorienteringer handler om, hvad eleven orienterer sig mod - og er afgørende for, hvad eleven engagerer sig i og deltager i. Pless plæderer for denne flerhed af motivationsorienteringer for at undgå ensidigt fokus på elevernes interesse- og vidensmotivation og for at vise, at "motivation i lige så høj grad kan skabes gennem mestringsoplevelser, involvering i læreprocesser, gennem præstationer og relationer" (Pless et al., 2015, s. 14).

\section{Sammenhæng mellem motivation og læring}

I tråd med tænkningen i Unges motivation i udskoling (Pless et al. 2015) ser vi motivation, som resultat af det, der foregår i undervisningen. Motivation er en forudsætning for læring, men den er ikke nødvendigvis givet på forhånd. Det er i forbindelse med elevens deltagelse i undervisningen, at denne drivkraft for læring kan styrkes - mere eller mindre. Således, at motivation og læring hænger sammen, og det kan være svært at adskille i praksis. 


\section{Kendetegn ved motivation og læring}

Læringstilgangen udtrykker forestillinger om, hvorledes læreprocesser bedst understøttes, samt tilgang til at forstå læreprocesser. Ditto ved teori om motivation. Tilbage står så at kunne sige, hvad motivation og læring faktisk er og hvad der kendetegner, at individet er i læring og er motiveret. Hertil vil vi læne os op ad følgende to forståelser.

\section{Tegn på læring}

Bech m.fl. forsøger sig på en tværgående definition af læring, der omfatter de forskelligartede læringssyn f.eks. både situerede- som mere individbårne læringssyn. Deres definition af læring lyder således: "Læring betegner alle de processer, hvor nogen forbedrer sin kunnen gennem et bevidsthedsarbejde, der er rettet mod en sådan forbedring" (Beck, Kaspersen, og Paulsen, 2014, 32). At læring er et bevidsthedsarbejde skal ikke her forstås som, at læring nødvendigvis kræver, at man er bevidst om læring; ej heller at læring nødvendigvis er en indre og individuel proces - men blot at læring er et stykke arbejde, hvor bevidstheden indgår. At eleven udviser et bevidsthedsdeltagende arbejde forstår vi i det følgende som, at eleverne er optagede, engagerede og deltagende i læreprocessen, at de involverer sig i processen og forfølger det, som handlingerne retter sig mod, nemlig at forbedre sin kunnen.

\section{Tegn på motivation}

Motivation kan siges at beskrive drivkræfter bag en persons handlinger og drivkræfter for læring. Her ses forhold som interesse, vilje til læring, og personligt engagement traditionelt som væsentlige elementer for at skabe en læringsproces. Det interessante for at forstå motivation er det handlingsledende aspekt. Beyer skriver, at motivation kan siges at høre til i spændingsfeltet mellem interesse og engagement, hvor engagementet betegner en personlig udfordring, som gør eleven "personligt involveret i læreprocessen og optændt af en vilje til at komme dybere ned i problemerne" (Beyer, 1999, p.285 og 289). Beyer skriver videre, at engagement synes at fremme det handlingsledende aspekt ved motivation (Beyer, 1999).

\section{Opsamling på første undersøgelsesspørgsmål og afsæt for analyse af sammenhæng mellem undervisning \& motivation og læring}

Med Beck et al. (2014) forståelse af læring kan vi tale om læring, når eleven er i et bevidsthedsarbejde mod at forbedre sin kunnen. Tager vi også afsæt i at læring jf. den sociokulturelle læringsforståelse, er situeret, grundlæggende social distribueret og medieret, så er det læringsfremmende, når der er mulighed for deltagelse i praksisfællesskaber, erfaringsdannelse gennem handling og en eksperimenterende tilgang.

Med Beyer's (1999) formulering kan vi sige, at, eleven er motiveret, når eleven er personligt involveret i læreprocessen, og optændt af en vilje til at komme dybere ned i problemerne, og at engagement synes at fremme det handlingsledende aspekt ved motivation.

Til at undersøge, hvordan undervisning gennem entreprenørskab påvirker elevernes motivation og læring, forholder vi os til om der er tegn på, at de didaktiske aktiviteter, som lærerne iværksætter, indikerer læring og motivation hos eleverne. Hvis det er tilfældet antager vi, at der er en sammenhæng mellem undervisningsformer udtrykt som de didaktiske greb, som læreren iværksætter, samt elevens motivation og læring.

\section{Udfoldelse af det andet undersøgelsesspørgsmål}

Til analysens andet undersøgelsesspørgsmål 'herunder hvordan elever, der er særligt udfordrede profiterer af denne form for undervisning' vil vi her udfolde de centrale begreber:

\section{Med 'profitere' forstår vi ...}

- at eleverne lærer og motiveres ... 


\section{Med 'elever der har særlige udfordringer' forstår vi ...}

Med elever, der har særlige udfordringer forstås elever, som er socialt udsatte og fagligt udfordrede. Følgeforskningens forforståelse er, at der på den ene side, er tale om elever, der er udfordrede i deres uddannelsesforløb på en måde, der synes at kræve en særlig opmærksomhed for, at de kan fastholdes i uddannelse og gennemføre denne - og på den anden side om elever, der imødekommer optagelseskrav til GF1 (Grundforløb 1) og har mulighed for at fortsætte i et hovedforløb. I denne ramme ligger der implicit en afgrænsning fra elever på EUD10 og produktionsskoler mv.

Forstudiet til denne følgeforskning (Day, Larsen og Sørensen 2016) beskæftiger sig ikke eksplicit med at afgrænse og udfolde en overordnet forståelse af, 'elever med særlige udfordringer'. Det har heller ikke været hensigten.

Forhold, der karakteriserer elever med særlige udfordringer kan være, som beskrevet i rapporten: Udsatte unge på erhvervsuddannelserne - imellem inklusion, marginalisering og fragmentering, (Brink Larsen, Brodersen, og Bjerre, 2015) der kategoriserer elevers udfordringer - ud fra professionelles syn - som faglige udfordringer, helbredsproblemer (med særligt fokus på psykiske udfordringer) samt sociale og psykosociale problemer. Det kan være forhold som ovenstående, der karakteriserer de udfordrede unge, som vi har talt med.

Baggrunden for unges faglige udfordringer kan være ordblindhed, sprog og sociale forhold $\mathrm{i}$ hjemmet og i skolen. Ifølge Videnopsamling fra Marselisborg Praksisvidencenter (2011, s. 24) er det et særligt problem for fagligt udfordrede, at de på grund af mange nederlagsoplevelser har en lav tiltro til, at de kan klare sig i uddannelsessystemet. Videnopsamlingen angiver, at disse elever derfor har et stort behov for løbende konstruktiv feedback, og for et overskueligt læringsmiljø med klare og tydelige rammer for arbejdet. Dette understøttes videre af Pless et al (2015), der anbefaler praksisorienteret didaktik, idet det kan give eleverne mulighed for at styrke faglighed og faglig selvtillid, gennem positive oplevelser af at se egen faglig udvikling.

Om sociale og personlige udfordringer, menes der ifølge (Kloppenborg og Wittrup, 2015) at kunne påvises, at psykisk og social sårbarhed mindsker den unges kapacitet til læring og uddannelsesvalg. Samtidig angives, at oplevelser af mestring i skolen kan understøtte selvtillid, identitetsudvikling og trivsel. Det synes at vise, at skolen kan have en vigtig rolle ift. at styrke eleverne psykisk og socialt.

Ift. at undersøge hvorvidt elever med særlige udfordringer kan profitere af en bestemt didaktik viser det sig i Forstudiet (Day, Larsen og Sørensen 2016, s. 4), at der kun findes ganske lidt forskning om betydning af didaktikken i relation til frafald og fastholdelse. Den forskning, der findes på området, synes at indikere, at det kan virke motiverende og fastholdende at arbejde praktisk i fællesskaber med mulighed for en vis selvbestemmelse, hvor man kan se, hvad man skal lære, og hvorfor det er relevant og gøre noget, der har værdi for andre (Ibid., s. 12).

\section{Undersøgelsesmetode}

Forstudiet og den teoretiske indkredsning af undervisning omhandlende entreprenørskab, motivation og læring har været nyttig til at åbne vores empiriske data fra observationer og interviews, til at se tegn, i lærernes didaktiske praksis og i elevens deltagelsesmåder, på hvordan eleverne har motivation og læring i sammenhæng til deres deltagelse i entreprenørskabsundervisning.

Vi har valgt en empirisk funderet strategi med inspiration fra både en social fænomenologisk og hermeneutisk orienteret tilgang, hvor lærernes og elevernes fortællinger om deres oplevelser af undervisning, motivation og læring i sammenhæng til entreprenørskab i undervisningen, er i centrum og en mere etnografisk inspireret metode, hvor vi gennem kort fokuserede feltarbejder 
observerer lærernes eksperimenter omhandlende entreprenørskab. Vi er bevidste om vores forforståelse, men under observation og interview er det den konkrete situationen og lærernes og eleveres fortællinger, som træder frem. Vi har som beskrevet ovenfor, primært brugt forstudiet som ramme til hvordan, data fra observationerne og interviewene efterfølgende fortolkes.

De anvendte dataindsamlingsmetoder er dokumentlæsning (eksperimentbeskrivelser), samt observationer under lærernes gennemførelse af undervisningseksperimenter i deres egen praksis. Der er foretaget individuelle interviews med lærere, og både individuelle, par og gruppeinterviews med elever på udvalgte skoler. Derudover er der blevet gennemført læringscirkler inspireret af metoden forskningscirkler (Persson 2008). Vi har valgt, at navngive dem læringscirkler fordi de adskiller sig fra forskningscirkler ved, at der kun bliver gennemført en enkelt cirkel i regi af udviklingsprojektet i slutningen på hvert diplomforløb, og analysens forskningsspørgsmål bliver først delt med de lærer, som gennemfører undervisningseksperimenter kort inden gennemførelsen af læringscirklen. Formålet med først at dele forskningsspørgsmål kort inden gennemførelsen af cirklen er, at spørgsmålet ikke har haft til hensigt at være retningsgivende for lærernes undervisningseksperimenter. På læringscirklerne bringes empirisk data, viden og erfaringer fra undervisernes uddannelseseksperimenter, og data fra den kvalitative følgeforskning i spil gennem videndeling og meningsudveksling, og udkommet af læringscirklen er med til at sætte retning for den videre udforskning, hos såvel forskere som undervisere.

\section{Datamateriale:}

Empirien er genereret, ved at følge 18 undervisningseksperimenter på erhvervsskoler inden for alle tre overordnede erhvervsskoleretninger Teknisk, Merkantil og Social og Sundhed

Empirisk materiale udvalgt til analysen er:

- 22 individuelle interviews med de lærere, der har gennemført undervisningseksperimenterne i entreprenørskab

- Forskellige former for interviews med i alt 67 elever, der har deltaget i lærernes undervisningseksperimenter. 8 elever har deltaget i individuelle interviews - de har alle oplevet udfordringer i forbindelse med deres skolegang. 22 elever har deltaget i parinterview, hvoraf mindst halvdelen er blevet udpeget af deres lærer som udfordrede elever, 27 elever har deltaget i gruppeinterviews med $3-5$ deltagere, hvoraf flere har tilkendegivet, at de har oplevet udfordringer i forbindelse med deres skoletid. De sidste 10 elever er blevet interviewet i par i forbindelse med en fremvisning og fremlæggelse. Derudover har mange elever givet deres betragtninger med under deres deltagelse $\mathrm{i}$ undervisningen, $\mathrm{i}$ forbindelse med vores deltagende observation.

- Empiriske notater fra to læringscirkler forår 2016 og efterår 2016

\section{Metodeovervejelser.}

\section{Kriterier for udpegning af udfordrede elever}

Alle deltagende elever går i normalklasser på EUD, og vi har ikke forlods udpeget kriterier for 'udfordrethed', men derimod ladet de deltagende lærere udpege elever til interviews, eller vi har under deltagerobservation valgt elever ud, som vi har talt med i sammenhæng med deres deltagelse i undervisningen, og i den forbindelse spurgt ind til deres tidligere skoleerfaringer. Ét enkelt sted ønskede læreren ikke at udpege elever som udfordrede, da læreren gav udtryk for, at differentiering udlignede forskellen, og i stedet meldte eleverne sig selv. Når lærere har udpeget elever, som særligt udfordrede, er det ud fra kriterier, som vi ikke kender til. I interviewene og i analysen lader vi de deltagende unges stemme komme frem, og lader dem fortælle om tidligere skoleerfaringer, og bringe disse i sammenhæng til de erfaringer, de oplever i forbindelse med 
deres deltagelse i lærernes undervisningseksperimenter omhandlende entreprenørskab. Således er der ikke genereret data om udfordrethed som sådan, men hvorledes de pågældende elever, der har deltaget i interviewene selv beskriver egen oplevelse af udfordrethed, og det er ud fra disse fortællinger vi baserer analysen om, hvordan elever der har særlige udfordringer kan profitere af denne undervisning. Således laver vi heller ikke en repræsentativ analyse af perspektiver hos forskellige unge - herunder unge med særlige udfordringer. Nærværende analyse sætter således fokus på elevernes egne fortællinger om den undervisning, de har deltaget i og deres subjektive beskrivelse af, hvad de mener at have fået ud af det.

\section{Kriterier for valg af undervisningseksperimenter}

Valg af undervisningseksperimenter er sket ud fra eksperimentbeskrivelser, som lærerne har udfærdiget i den første del af deres diplomforløb. De udvalgte undervisningseksperimenter til analysen baserer sig ikke på en forudgående vurdering af, hvorvidt eksperimenterne kan siges at være entreprenørskabsundervisning - som i Fondens definition. Derimod har kriteriet været, hvorvidt eksperimenterne udtrykker en klar målsætning og dertilhørende didaktik, hvor forskellige parametre af entreprenørskabsundervisning fremstår tydeligt. Udvælgelse af eksperimenter er sket i to tempi. De første eksperimenter blev udvalgt, fulgt og analyseret under udviklingen af første diplom forår 2016. De efterfølgende under diplommodulet, efterår 2016. Under anden udvælgelse, udvælger vi kun forløb, der strækker sig over mindst en uge, da vi vurderer, at det ikke er muligt for hverken eleven eller læreren at sige noget gyldigt om motivation og læring, hvis der kun er tale om elevens deltagelse i et undervisningseksperiment omkring entreprenørskab på en enkelt dag. De eksperimenter, der har været udvalgt i pilot 1 og som er en dag eller derunder, vurderer vi kun har karakter af en enkelt undervisningsaktion og ikke et eksperiment jf. eksperimenthjulet (Hutters og Sørensen, 2015), og indgår derfor ikke i analysen.

De fleste af eksperimenter har en varighed på omkring en uge, og enkelte eksperimenter strækker sig over flere uger. Det skal desuden bemærkes, at nogle af undervisningseksperimenter tog form af tværfaglige forløb, som optog alle undervisningstimer i forskellige fag, mens andre forløb blev gennemført i specifikke fag, andre igen blev gennemført som projektforløb i innovation på EUD Social og sundhed.

De eksperimenter som vi har udvalgt er karakteriseret ved overvejende at repræsentere en af de tre former for, om og gennem entreprenørskabsundervisning (Moberg 2014). Det er eksperimenter hvor undervisningen er tilrettelagt gennem entreprenørskab med afsæt i almindelige læringsmål som ramme for udvikling af entreprenørskabsundervisning. Kun et eksperimentforløb kan siges at være inspireret af undervisning for entreprenørskab. For nærmere uddybelse af analysens forståelse af undervisning gennem entreprenørskab, se side 8 eller i nedenstående skema over begreber som vi anvender i analysen.

Det skal bemærkes, at nogle af de didaktiske designs, og de aktioner som lærerne har beskrevet i deres eksperimentbeskrivelse, ikke har kunnet realiseres helt præcist efter deres plan, da enten aftalte rammer for gennemførelse er blevet ændret eller forskellige hverdagsudfordringer, som f.eks. ændring i skema eller andet har forhindret gennemførelse. Men i alle de tilfælde, hvor udgangspunktet er blevet ændret, er det alligevel lykkedes læreren at gennemføre undervisnings-eksperimenter; dog ikke helt som planlagt og beskrevet i eksperimentbeskrivelsen, hvilket selvfølgelig så også har indflydelse på, hvilke data vi har kunne opsamle i den faktiske gennemførte undervisning. 


\section{Empirisk analyse}

\section{Analysebegreber}

Som beskrevet i foregående afsnit er det lærernes didaktiske handlen og elevernes erfaringer med deltagelse i undervisningsforløb omhandlende entreprenørskab, som danner afsæt for analysen.

I analysen vil adskillige analytiske begreber blive nævnt undervejs, og nedenstående begrebsafklaring har til formål at skabe overblik over hvordan begreberne bruges i analysen.

\begin{tabular}{|c|c|}
\hline Didaktiske billeder & $\begin{array}{l}\text { I analysen fremstiller vi forskellige typer af didaktiske billeder, som hver } \\
\text { belyser det didaktiske rum som undervisningseksperimenterne gen- } \\
\text { nem entreprenørskab udspiller sig i. De didaktiske billeder er fremstillet } \\
\text { med de forskellige blik Første blik zoomer ind på måder til at kompe- } \\
\text { tenceudvikle eleverne. Andet blik zoomer ind på elevernes måder, at } \\
\text { deltage i undervisningen på og tredje blik zoomer ind på, hvordan ele- } \\
\text { ver med særlige udfordringer kan profitere af undervisning gennem en- } \\
\text { treprenørskab. }\end{array}$ \\
\hline Analytiske blik & Med blik forstår vi, en afgrænset indsigt udtrykt gennem billeder. \\
\hline Didaktiske greb & $\begin{array}{l}\text { Didaktiske greb er de aktiviteter, handlinger, og måder at tilrettelægge } \\
\text { undervisningen på, som lærerne benytter sig af, for at fremme elever- } \\
\text { nes entreprenørielle kompetencer og åbne for nye deltagelsesmåder. }\end{array}$ \\
\hline Didaktiske forhold & $\begin{array}{l}\text { Didaktiske forhold er blevet fremanalyseret på baggrund af de didakti- } \\
\text { ske greb, som fremstilles i de didaktiske billeder. De didaktiske forhold } \\
\text { er tværgående, og det er forhold, som er blevet identificeret som sær- } \\
\text { ligt betydningsfulde didaktiske forhold for at lykkes med entreprenør- } \\
\text { skabsundervisning, der udvikler elevernes entreprenørielle kompeten- } \\
\text { cer. }\end{array}$ \\
\hline Didaktiske principper & $\begin{array}{l}\text { Didaktiske principper er principper inden for de fire dimensioner (kreati- } \\
\text { vitet, handling, omverdensrelation, og personlig indstilling), er blevet } \\
\text { identificeret af Fonden for entreprenørskab som værende didaktiske } \\
\text { principper, der potentielt gør undervisningen mere entreprenøriel. }\end{array}$ \\
\hline $\begin{array}{l}\text { Didaktiske markører } \\
\text { for entreprenør- } \\
\text { skabsundervisning }\end{array}$ & $\begin{array}{l}\text { I analysen anvendes didaktiske markører som samlende benævnelse } \\
\text { for didaktiske greb inden for samme kategori, der fremme samme for- } \\
\text { mål med undervisningen. }\end{array}$ \\
\hline $\begin{array}{l}\text { Undervisning gen- } \\
\text { nem entreprenørskab }\end{array}$ & $\begin{array}{l}\text { I denne analyse bruger vi benævnelsen gennem entreprenørskab, i be- } \\
\text { tydningen, at undervisningen tones entreprenørielt. I den form som vi } \\
\text { bruger benævnelsen gennem entreprenørskab (Hannon, 2005) skelner } \\
\text { vi ikke mellem undervisning gennem entreprenørskab (Hannon, 2005) } \\
\text { og at entreprenørskab er indlejret eller embedded i undervisningen } \\
\text { (Fondens udlægning efter inspiration af Pittaway \& Edwards 2012). } \\
\text { Gennem entreprenørskab betyder i denne analyse, at eleven deltager i } \\
\text { et entreprenørielt forløb, hvor fokus er på læringsmetoder og det at } \\
\text { lære gennem en entreprenøriel proces. Undervisningsforløbets almin- } \\
\text { delige læringsmål kan opnås samtidigt med, at elever og studerende } \\
\text { klædes på med handlingsorienterede kompetencer, samt evnen til at } \\
\text { handle entreprenørielt og foretagsomt. }\end{array}$ \\
\hline
\end{tabular}


Fonden for Entreprenørskab har udarbejdet nogle didaktiske principper, der understøtter de fire dimensioner inden for entreprenørskab, og potentielt forventes at gøre undervisningen entreprenøriel (Fonden for Entreprenørskab, 2016). Disse didaktiske principper vil vi blandt andre bruge i analysen, som didaktiske markører for entreprenørskabsundervisning, der hjælper til at se lærernes didaktiske greb i sammenhæng til elevernernes udvikling af entreprenørielle kompetencer. De didaktiske markører, som vi identificerer værende på spil i lærerens undervisning, vil vi illustrere gennem empiriske billeder, der belyser undervisningssituationer, hvor undervisningen får karakter af at være eksempler på entreprenørskabsundervisningen.

De didaktiske greb, som lærerne vælger at bruge i deres undervisningseksperimenter, er skrevet frem i nedenstående billeder, fordi de knytter sig til intentioner om at fremme entreprenørielle kompetencer hos eleverne.

\section{Analysens opbygning}

Undervisningen på diplommodulet har taget udgangspunkt i en forståelse af entreprenørskab, som en kompetence, der er sammensat af fire komplementære og indbyrdes afhængige kompetenceområder, som af fonden betegnes som fire entreprenørielle dimensioner. (Fonden for Entreprenørskab, 2016). De fire entreprenørielle dimensioner forstået som kompetencer er:

1.handling til at blandt andet at iværksætte initiativer og at virkeliggøre disse gennem samarbejde, netværk og partnerskaber, 2. kreativitet til blandt andet at se og skabe idéer og muligheder, til divergent og abduktiv tænkning og til at kombinere viden fra forskellige områder på nye måder, 3. omverdens relation til blandt andet at kunne iagttage, analysere og konstruere en social kulturel og økonomisk kontekst som arena for værdiskabende handlinger og aktiviteter. 4. personlig indstilling til blandt andet at overkomme ambivalens, usikkerhed og social kompleksitet og at kunne arbejde vedholdende. Det er også kompetence til at kunne accepterer og lære af andres og egne fejl og at kunne foretage etiske vurderinger og refleksioner (Fonden for Entreprenørskab, 2016).

Det empiriske materiale har vist, at lærerne på diplommodulet i høj grad har været optaget af at omsætte disse fire dimensioner, som selvstændige undervisningstematikker i deres undervisningseksperimenter.

Som det fremgår i beskrivelsen af design for følgeforskningen, så vil vi her arbejde med at undersøge elevernes motivation og læring, når de deltager i de undervisnings-eksperimenter omkring entreprenørskab, som lærerne gennemfører. I det følgende afsnit vil vi gennem brug af eksempler og citater fra empirien undersøge, hvordan de didaktiske greb fra undervisningen udtrykker sammenhæng til elevens motivation (dvs. elevens engagement - herunder personlig involvering og optændthed af vilje til at komme dybere ned i problemerne), og sammenhæng til elevernes arbejde med at lære (dvs. elevens arbejde med at forbedre sin kunnen gennem et bevidsthedsarbejde).

Analysen er delt i to. Først en empirisk båret didaktisk analyse, der tager afsæt i dataindsamlingen. Denne leder frem til udpegning af en række didaktiske forhold, der i særlig grad synes at have betydning for hvordan elevernes motivation og læring skabes i undervisningen gennem entreprenørskab. De didaktiske forhold er fremkommet gennem en analyse af de didaktiske greb, som lærerne har brugt i forskellige undervisningssituationer, altså deres didaktiske intentioner og handlinger, for at fremme elevernes entreprenørielle kompetencer gennem motivation og læring.

Dernæst diskuterer vi vores fund i den empiribårne didaktiske analyse, med teori om motivation og læring fra forstudiet, i sammenhæng til Fonden for entreprenørskabs forståelse af entreprenørskabsundervisning. Dette med henblik på at drøfte, hvordan den undervisning, som læreren 
anvender udvikler elevernes entreprenørielle kompetencer, og under dette læringsarbejde undersøge, hvordan det påvirker elevernes motivation og læring og lyst til deltagelse i uddannelse,

Slutteligt vil vi pege på, hvordan man fremadrettet kan arbejde med didaktiske forhold, der relaterer sig til entreprenørskabspraksis, og derfor har betydning for, på hvilken måde lærerne tilrettelægger og gennemfører undervisning gennem entreprenørskab på erhvervsuddannelserne.

Den empiribårne didaktiske analyse består af tre analytiske blik.

- Det første blik er didaktiske billeder på, hvordan lærerne tilrettelægger deres entreprenørskabsundervisning, gennem didaktiske design inden for de fire entreprenørskabsdimensioner, med henblik på at udvikle elevernes entreprenørielle kompetencer gennem motivation og læring. Dette blik giver os en indsigt i lærernes undervisning og deres didaktiske overvejelser. I dette blik er beretninger fra elever med særlige udfordringer indeholdt i de didaktiske billeder, der fremstilles.

- Analysens andet blik er didaktiske billeder på elevernes deltagelsesmåder, hvor vi undersøger hvordan eleverne deltager i den entreprenørskabsundervisning, som er genereret gennem undervisningseksperimenter. Når vi vælger at se på elevernes deltagelse, så er det fordi vi forstår deltagelse som et tegn på at eleverne er i proces med at udvikle de føromtalte entreprenørielle kompetencer, belyst gennem entreprenøriel adfærd, knyttet til dimensionerne i entreprenørskabsundervisning. Her er det kontekstuelle og uddannelsesspecifikke i fokus, så vi får viden om hvad der, ved entreprenørskab i erhvervsuddannelserne, åbner for deltagelsesmåder, som påvirker elevernes motivation og læring. I dette blik er beretninger fra elever med særlige udfordringer også indeholdt i de didaktiske billeder, der fremstilles.

- Analysens sidste tredje blik er 'særlig udfordrede elever'. Dette blik har vi fremstillet omkring tværgående didaktiske tematiseringer, som har åbnet sig under de første to blik og under selve analysen omkring de særlig udfordrede elever. Temaerne er i 3. blik rammesat med didaktiske markører som i de to foregående blik,

Fokus er altså på, hvordan den situerede brug af entreprenørskabsdidaktik organiserer undervisningen, og den kompetenceudvikling gennem motivation og læring, som det åbner for.

\section{Første blik - Didaktiske billeder på udvikling af entreprenørielle kompetencer i undervis- ningen}

Nedenfor udvikles billeder på didaktik, der inden for hver af de fire dimensioner ser ud til at påvirke elevers læring, motivation og lyst til at deltage i uddannelse (jf. forskningsspørgsmålet). Under hver af de fire dimensioner har vi, som skrevet i det foregående afsnit, desuden brugt udvalg af Fonden for Entreprenørskabs didaktiske principper, som didaktiske markører for entreprenørskab, der hjælper os til at se lærernes didaktiske greb i sammenhæng til undervisningen omhandlende entreprenørskab. Der er i de didaktiske billeder lagt vægt på at beskrive, hvilke didaktiske greb lærerne bruger i deres undervisning, for at fremme én eller flere entreprenørielle kompetencer hos eleverne. Hvert billede er rammesat under en dimension og udvalgte didaktiske markører, der er med til at fremme dimensionen og dermed potentielt øge elevernes mulighed for at udvikle kompetence inden for dimensionen. Det skal dog påpeges, at hver undervisningssituation under de forskellige billeder, ikke lader sig afgrænse af opdelingen mellem dimensionerne med tilhørende didaktiske markører for entreprenøriel praksis i undervisningen. Flere af situationerne understøtter alle fire dimensioner, og flere didaktiske greb er til stede i situationerne. Dette forhold illustrerer blot betydningen af det kontinuerlige dialektiske samspil mellem dimensionerne. En lærer fra en landbrugsskole illustrerer det er nedenstående citat: 
"inddragelse af omverden, som ligger uden for elevernes komfortzone, betyder en ændring af personlig indstilling som del af tilrettelæggelse af et projekt. Det åbner, for elevernes kreative side"

\section{Handling}

Når eleven selvstændigt og i samarbejde med andre kan tage ansvar for at organisere, planlægge og gennemføre værdiskabende faglige opgaver og forholde sig refleksivt til sammenhænge mellem ressourcer, proces og resultater (Fonden for Entreprenørskab, 2016, s. 16) er det et tegn på, at eleven er ved at udvikle handlingsorienterede kompetencer i sammenhæng til entreprenørskab.

Didaktiske markører for entreprenørskabsundervisning, under dimensionen handling, er: at arbejde med værdiskabende og forandrende aktiviteter/projekter, at arbejde med involvering og inddragelse af elever og studerende, at give elever og studerende ansvar for aktiviteter, at anvende viden og færdigheder i forskellige kontekster, at tage afsæt $i$ forskellige kontekster for aktiviteter, at anvende netværk og relationer, at stimulere varierende præsentationsformer, at invitere til refleksion i forhold til handling (Didaktiske principper, Fonden for Entreprenørskab, 2016:27)

\section{Billede 1, Didaktisk markør for handling i entreprenørskabsundervisning:} Arbejde med værdiskabende og forandrende aktiviteter/projekter.

På en EUD Social og Sundhed fortæller en lærer, at hun gennem sit eksperiment har haft fokus på 'modtagerværdi', og at elevernes projekter skulle 'rettes mod nogen'. Eleverne tog blandt andet afsæt i 'frustrationer' oplevet i forbindelse med deres praktik. Underviserens brug af elevfrustrationer, førte til erfaring af både at kunne handle og skabe samtidig værdi for andre. Nedenstående citat er fra en observation, hvor læreren spørger eleverne, hvad de har fået ud af at arbejde på denne måde:

Lærer: Det I lærte i danskundervisningen, tænker I, at I kan bruge noget af det I lærte? Tænker I, at I vil kunne bruge det når I kommer ud?

Elev 2: Ja det tror jeg. Den der lyst til selv at generere et eller andet -at man opdager, at der er noget der mangler og så ...

Elev 1: Jeg er nok også blevet mere OBS på det

Lærer: At du selv kan gøre noget?

Elev 1: Ja.

Lærer: Fået mere blod på tanden eller hvad kan man sige?

Elev 1: Ja".

Eksemplet fra denne entreprenørskabsundervisning viser, at værdiskabende og forandrende aktiviteter med fokus på 'modtageren' kan hjælpe eleverne med at vende egne frustrationer til ny motivation og læring. 


\section{Billede 2, Didaktisk markør for handling i entreprenørskabsundervisning:}

Give elever og studerende ansvar for aktiviteter

I et eksperiment på en landbrugsskole fortæller en lærer, at han er begyndt med at lade eleverne søge viden selv, og trouble-shoote undervisning, frem for at bruge traditionel tavleundervisning. Ved at lade eleverne arbejde i korte sekvenser, hvor de selv søger information til undervisningen, tager eleverne større ansvar for at finde, vælge og læse litteratur og dermed også vælge retning.

\section{En gruppe elever fortæller:}

"Ja, jeg får mere ud af det, når jeg selv læser det, og når det er noget, man selv synes er interessant. Man er selv med til at udfordre, hvor man vil hen".

"Vi finder selv det, vi skal læse. Vi får [det] ikke at vide."

"Det er nemmere, at gøre interessant"

"Den der med det ustrukturerede... man føler i starten at man ikke rigtig ved, hvor man vil hen... men så kommer det."

"Jeg har lært, at jeg kan meget mere end hvad jeg har troet, set nye sider af mig selv. Fået mere lederegenskab. Man har lært at tage mere ansvar også... for en gruppe, eller for to personer. Og også være god til at sige, i dag skal vi lave det her, og det her, og det her, $i$ stedet for bare at sige, at vi skal komme i gang"

Interviewer: "Hvad er det i undervisningen, der gør det?"

"Det er at man får så frie tøjler... hvis du ikke laver noget, så lærer du ikke noget. Du får hjælp, hvis du spørger. Hvis vi har spurgt, så har han ikke sagt præcist, hvad vi skulle gøre, men mere noget med: tænk i de her baner.".

I samme klasse kan vi kan samtidigt se, at læreren har en vigtig rolle i forhold til at være opmærksom på elevers usikkerhed og skabe muligheder for, at alle elever finder strategier for at overkomme bekymringer eller usikkerhed i forhold til at tage ansvar for aktiviteter, projekter og samarbejde. Et eksempel på hvordan læreren anvender et didaktisk greb for at skabe undervisning, der giver elever og studerende ansvar for aktiviteter til at udvikle elevernes personlige indstilling, ses i nedenstående eksempel. Læreren opdager, at en gruppe elever føler sig frustrerede fordi de ikke ved, hvordan de skal tage kontakt til en virksomhed. Ved at snakke med eleverne om deres usikkerhed og lave en prøvesession, får eleverne mod til at kontakte virksomheden. Læreren fortæller:

"Hvis jeg spørger dem i dag, så vil de bare gøre det. Nu ved de, det gør ikke ondt, og det kan man sagtens".

Eksemplet fra denne undervisning viser, at læreren har en vigtig rolle i forhold til at give eleverne mulighed for at arbejde konstruktivt med deres usikkerhed således, at eleverne får positive erfaringer med at handle og tage ansvar.

Det didaktiske billede viser, at lærerens tro på, at eleverne selv er i stand til at sætte retning, stille spørgsmål, søge svar og i det hele taget være eksperimenterende og undersøgende, ser ud til at give eleverne lyst til at tage ansvar for aktiviteter og tro på, at de er i stand til selv at foretage faglige vurderinger og valg. Observationer viser, at det kan være en udfordring for nogle af eleverne at arbejde på denne måde, og at læreren har en vigtig opgave i at synliggøre alle elevers bidrag til den eksperimenterende undervisning, herunder skabe varierende deltagelsesmuligheder, så alle elever får positive erfaringer med den eksperimenterende tilgang til det faglige. 


\section{Billede 3, Didaktisk markør for handling i entreprenørskabsundervisning:}

Invitere til refleksion i forhold til handling

Det følgende undervisningseksempel viser, at eleverne ved at reflektere over gruppesamarbejdet, kan udvikle nye selvopfattelser og perspektiver på 'at tage ansvar for at organisere, planlægge og gennemføre værdiskabende og faglige opgaver i samarbejde med andre'. Eksemplet viser også, at læreren har et ansvar for at synliggøre elevernes erfaringer og støtte eleverne til at trække læring ud af negative samarbejdsoplevelser.

Eksemplet er taget fra EUD Social og Sundhed, hvor en lærer inviterer en gruppe elever ind til en samtale et stykke tid efter, at elevernes projekt er blevet afsluttet. Læreren fortæller inden samtalen, at gruppen havde svært ved at samarbejde og at det havde påvirket eleverne en del. Læreren beder eleverne om at fortælle, hvordan de hver især har oplevet samarbejdet, og hvordan deres egne reaktioner og valg kom til at forme projektet. Citatet er fra observationen af samtalen mellem læreren og eleverne:

"Elev 2: Jeg har lært, hvem man kan samarbejde med og hvem man ikke kan med, ikke negativt. Jeg har bare lært, at nogle mennesker fungerer ikke til at være i gruppe sammen. Og det der med, at man hele tiden skal forholde sig til andres ideer og sådan noget. Jeg har også lært, at være lidt mere forsigtig med at skyde andres ideer ned og, at det faktisk er nemmere [at skyde idéer ned, red] end man tænker over. At man gør det [skyder ned] uden at tænke over det. [....]

Lærer: Var det for frit, det her med at der ikke var nogen af jer der tog ansvar? At der ikke var en leder? Ville I gerne have haft en lærer, der sagde "nu gør I sådan, sådan og sådan"?

Elev 2: Måske fordi der ikke er nogen af os, der er ledertypen, det kæver sådan lidt en bestemt type, at der er en, der går ind og gor det.

Lærer: Ja. Var der nogen af jer der havde lyst til det?

Elev 1: Man tænkte da nogen gange. Altså jeg tænkte mange gange "nu bliver du snart nødt til at gøre noget". Men jeg har det bare dårligt med mig selv. Jeg er ikke god til at sige "gør det her og gør det her", hvis det er nogen jeg føler jeg er lige med.

I eksemplet ser vi, at læreren indtager en rolle, hvor det bliver legitimt at stille spørgsmål til elevernes erfaring fra deres samarbejde i gruppen under deres entreprenørskabsprojekt.

I et andet undervisningsforløb fra EUD social og sundhed bliver det tydeligt, at læreren er særlig aktiv i forhold til at spørge ind til hvad eleverne vil gøre ved de problemer de rejser og hvordan de vil gøre det. Læreren tager hyppigt elevernes egne spørgsmål op til debat og lader eleverne belyse spørgsmål og problematikker i fællesskab. Adspurgt om, hvordan det er, at læreren ikke giver ét bestemt svar på faglige spørgsmål og ikke siger, hvad der er rigtigt og forkert siger eleverne:

"Elev: [Det var] møg irriterende til at starte med, men man kan jo godt, nu når vi er ved at være $i$ slutningen af skoleperioden så kan man godt se "okay, der er jo en grund til at hun ikke gør det" fordi psykiatrien er så bred som den er, så der er ikke altid et konkret svar. ... Elev: I psykiatrien er der ingen facit, det er jo så forskelligt fra menneske til menneske til hvordan og hvorledes vi skal håndtere situationerne. Nogle ville jo stille sig op og sige $i$ denne her situation der skal I gøre sådan. Men det er jo ikke lige sikkert, at det er det der virker på Hr. Hansen. Så det er jo meget forskelligt..." 
Lærerens insisteren på at eleverne selv er i stand til at finde svar og begrunde deres valg, ansporer eleverne til at tage ansvar for den aktivitet eller det projekt, som de er en del af, og tro på at de kan håndtere situationer, hvor de selv må træffe et fagligt valg.

Vi kan se, at læreren har en vigtig rolle i forhold til at være opmærksom på elevers usikkerhed og skabe muligheder for at alle elever finder strategier for at overkomme bekymringer eller usikkerhed i forhold til at tage ansvar for aktiviteter, projekter og samarbejde. Konstruktiv og anerkendende feedback fra læreren og fra medstuderende ser ud til at gøre eleverne mere trygge i at arbejde entreprenørielt. Feedback kan også hjælpe med at synliggøre elevens kompetencer, så eleven 'får øje på sig selv' og den værdi eleven tilfører et projekt, en ide eller et samarbejde.

Vi er blevet opmærksomme på, betydningen af elevsamarbejde som støtte til læreprocesser. I nogle undervisningseksperimenter omhandlende entreprenørskab har gruppearbejde givet eleverne en erfaring med hvem, de kan arbejde sammen med og hvem, de ikke kan. Det vil sige at indholdet i læringen kan komme til primært at være læring om samarbejde til forskel fra samarbejde, som styrker et læringsindhold.

\section{Kreativitet}

Når eleven kan tage ansvar og arbejde vedholdende eksperimenterende og undersøgende med kreative processer inden for et praktisk fagligt felt (Fonden for Entreprenørskab, 2016) er det et tegn på, at eleven er ved at udvikle kreative kompetencer i sammenhæng til entreprenørskab.

Didaktiske markører for entreprenørskabsundervisning under dimensionen kreativitet er: at arbejde med eksperimenterende aktiviteter, at skabe tidsrum uden bedømmelse, at arbejde med skabende aktiviteter, at sikre faglig fordybelsestid, at tage afsæt i forskellige kontekster for aktiviteter, at stille åbne og umulige opgaver, at involvere flere sanser, at invitere til refleksion i forhold til fantasi og kreativitet (Didaktiske principper, Fonden for Entreprenørskab, 2016:27). 


\section{Billede 1, Didaktisk markør for kreativitet i entreprenørskabsundervisning:}

Arbejde med eksperimenterende aktiviteter

"De har svært ved at være kreative. De holder sig inden for den kendte ramme. I går var chefen for COOP på skolen for at holde oplæg. COOP har sat plads af på hylderne til lokale varer, men eleverne tøver. - Hvis de skal være mere forbrugerrettede, skal de ikke lave budgetter på 1000 søer, men på skovgrise." (Lærerinterview, Landbrugsskole).

"Hvad er det, de [eleverne] ser? Nu kommer jeg hjem og overtager fars ejendom. De bliver ikke opfordret til at tænke anderledes. Fædrene siger ikke, de skal tænke anderledes. - De tænker vækst frem for værditilvækst." (Lærerinterview, Landbrugsskole).

Ovenstående citater fra et undervisningseksperiment, gennemført på en Landbrugsskole, viser behovet for, at underviserne tilrettelægger undervisningen med en eksperimenterende tilgang for øje, da der ellers er fare for, at eleverne bliver fastholdt i en konservativ forståelse af, hvad der skaber værdi i branchen. Eksperimentet har givet underviseren en tydelig indsigt i de forforståelser mange landbrugselever kommer med, og underviseren siger samtidigt at skolen understøtter denne tilgang til branchen gennem fagets indhold, form og metoder. Formålet med den eksperimenterende arbejdsform, i sammenhæng til kreativitet, er at støtte elevernes udvikling hen imod en mere entreprenant tilgang i forhold til fag og branche. Eksemplet fra eksperimentet viser, at det er ikke nok at få et besøg fra en virksomhed og høre et oplæg, der lægger op til aktiviteter, der kan fremme elevens entreprenante mindset. Læreren skal skubbe, og den åbne og eksperimenterende tilgang skal tilrettelægges.

Landbrugseleverne fra ovenstående eksperiment siger om entreprenørskabsundervisning:

"It makes you explore, it is more comfortable, when teachers ask you to read a book it is like they expect copy-paste, and they don't know what we really know. You don't have to think (classroom learning), you have to think, because it is practical. He (læreren) finds out what we really know (by seeing the post-its)" (Elevinterview, Landbrugsskole).

Dette første didaktiske billede belyser, at der er en sammenhæng mellem lærernes didaktiske overvejelser i forbindelse med entreprenørskabsundervisning og elevernes muligheder for at aktivere kreativ handlen gennem en eksperimenterende tilgang. Traditioner og kultur, fag og faglige tilgange kan både forhindre og muliggøre motivation og læring i sammenhæng til entreprenørskab. 


\section{Billede 2: Didaktisk markør for kreativitet i entreprenørskabsundervisning:}

Stille åbne og umulige opgaver

Eleverne fra EUD Social og Sundhed deltog i et undervisningseksperiment omhandlende entreprenørskab, hvor de fik stillet en åben opgave om bæredygtighed med energioptimering som underemne. Eleverne fik forskellige udfordringer i form af cases, som skulle hjælpe dem med at få retning og derefter få idéer til at åbne opgaven op. Den udfordring, som eleverne valgte at arbejde med, skulle formidles gennem et konkret produkt: en APP, sortering af skrald eller et spil. I denne sammenhæng udspiller kreativitet sig i og omkring en praksis, der er udlagt som fagligt entreprenørskab, hvor udfordringer, der kalder på løsninger eller spørgsmål, skal åbne for muligheder (indkredsning af kreativitet Fonden for Entreprenørskab, 2016, s. 23). I eksemplet ses, hvordan lærerens didaktiske overvejelser i forbindelse med undervisningseksperimenter gennem entreprenørskab skaber muligheder for elevernes kreative kompetencer gennem eksperimenterende tilgange.

På en supportuddannelse oplevede eleverne, at metoder som Brainstorm kan være med til at åbne for idéer til løsning på udfordringer: "Brainstorm er god fordi man kommer frem med alt, og de andre lytter med. Læreren vejleder" (Elevinterview, EUD Teknisk).

Eksemplet her viser, ved at eleven siger, at man kommer frem med alt, at metoden er med til at åbne op for viden. Det har også betydning, at de andre (i gruppen) lytter med. Det viser, at eleven tillægger gruppen og videndelingen betydning som vigtige afsæt for den videre læring. Læreren har med didaktiske overvejelser over, hvordan metoden skal anvendes (eleverne skal dele deres idéer, én elev skal tale ad gangen, de andre skal lytte) og, at det sker i grupper med henblik på samarbejde, er ikke tilfældige overvejelser, men overvejelser, der i ovenstående eksempel viser, at det didaktiske design omkring brugen af brainstorm som åbner for idéer til indkredsning af en udfordring, understøtter elevens aktive deltagelse og der igennem motivation og læring.

Et eksempel fra et andet eksperiment fra EUD Social og Sundhed belyser en ideproces, hvor eleven føler sine idéer bedømt som dårlige idéer, og hvordan åbenhed spiller en central rolle i at fremme kreative kompetencer hos eleverne:

"Havde selv ideer, men læreren sagde, at det ikke var en god ide. Det gentog sig flere gange" (Elevinterview, EUD Social og Sundhed)

Her bliver det relationelle forhold mellem eleven og læreren - i forhold til den åbne opgave, der er stillet - oplevet af eleven som vurderende (god eller dårlig ide), i modsætning til det tidligere eksempel, hvor eleverne giver udtryk for at læreren er mere vejledende.

Dette eksempel belyser, at en metode ikke gør motivation og læring i sig selv, men at lærerens tilrettelæggelse, samspil og lærertilgang har stor betydning for dette.

Det andet didaktiske billede belyser de mange forhold - ud over metode - som lærere skal overveje, når de skal arbejde med åbne opgaver. I materialet ses forskellige metoder til at åbne for, at eleverne skal være kreative i starten af en entreprenøriel læringsproces. I de eksperimenter, som lægger til grund for denne analyse, har der ligeledes været anvendt flere forskellige metoder til at åbne for elevernes idéer så som: Brainstorm, drømmeværksteder (waltifisering), fishbowl med mere. 


\section{Billede 3: Didaktisk markør for kreativitet i entreprenørskabsundervisning: Invitere til refleksion i forhold til fantasi og kreativitet}

Et eksempel på hvordan læreren forsøger at fremme elevernes kreative kompetencer, er ved hjælp af det didaktiske greb at invitere til refleksion i forhold til fantasi og kreativitet. Dette ses i et undervisningseksperiment omhandlende entreprenørskab på et GF2 hold på IT-support, hvor læreren har inviteret til refleksion ved at give eleverne nogle benspænd her forstået som udfordringer - i deres udvikling af idéer. Læreren siger om sine didaktiske erfaringer med dette: "Det virker at bruge 'benspænd' (teoretiske forhindringer uddelt ved lodtrækning) som en del af pædagogisk praksis".

Lærerens vurdering af et didaktisk greb for at fremme refleksion i forhold til fantasi og kreativitet understøttes af et elevudsagn:

"... de her benspænd har givet mig flere ideer til hvordan jeg kunne bygge videre på app'en [...] så jo, jeg vil sige at det har været meget godt til at give mig flere ideer" (Elevinterview, EUD Teknisk)

Dette belyser igen hvordan lærerens didaktiske overvejelser, er centrale for udviklingen og kvalificeringen af ideer, og dermed udviklingen af elevernes kreative kompetencer.

I et andet eksperiment er der den samme erfaring med hensyn til at anvende metoder, der kan være med til at stille spørgsmål til idéer. En elev udtaler:

"Godt med metoden til at stille spørgsmål til idéer. Det kan hjælpe til at kvalificere" (Elevinterview, EUD Social og Sundhed).

Dette elevudsagn er med til at belyse, hvad det er refleksion kan være med til at muliggøre. Eleven peger på, at det hjælper til at kvalificere idéer. Det kan tolkes som, at metoden er med til at sikre, at eleverne bringer deres idéer i sammenhæng til omverden gennem forestillinger om anvendelse. I denne sammenhæng kan anvendelse også forstås som værdiskabelse for andre.

I et tredje eksperiment, som foregår på EUD Social og Sundhed, fortæller en elev om, hvilken betydning lærerens rolle har for udvikling af refleksion i forhold til fantasi og kreativitet:

"Læreren skulle være lidt på sidelinjen, og hun skulle altid være klar, hvis gruppen eller andre grupper gik i stå, så skulle hun komme ind og støtte os, give feedback.

Hun [læreren] sagde "okay nu er I gået i stå..., hvad nu hvis I lige prøver at"... Hun [læreren] siger også -..."tænk lige, - vend den lige om på en anden måde". Hver gang vi gjorde det, så fik vi en million nye tanker og ideer" (Elevinterview, EUD Social og Sundhed).

Dette citat belyser også betydningen af feedback og skub, som didaktisk aktivitet til at fremme refleksion i forhold til fantasi og kreativitet. Eleven giver udtryk for, at lærerens små skub, feedback og opmærksomhed på gruppens arbejdsflow er med til at åbne for nye tanker, der kan bringe fantasi og kreativitet yderligere i spil.

Dette sidste didaktiske billede inden for kreativitetsdimensionen belyser, hvad der fremmer elevernes motivation for at arbejde videre med deres idéer, og sammenhænge til lærerens didaktiske overvejelser om anvendelse af forskellige tiltag, der kan være med til at skubbe eleverne videre, åbne for deres fantasi og dermed arbejde mere kreativt med deres idéer. 
Lærerens aktive deltagelse, skub og engagement i elevers og gruppers arbejde er tydeligt med til at åbne og skabe muligheder og dermed mere kreativ læring. Det sker ved, at eleverne reflekterer over deres idéer i forhold til omverden og iværksættelse. Eksemplerne synes at vise, hvorledes invitationer til kreativitet gennem 'nye og anderledes ideer' understøtter elevens bevidsthedsarbejde på at forbedre sin kunnen (om at bygge APP) gennem det at udfordre og forfine ideer til opgaveløsning, hvilket understøtter motivationen og læringen. Vi ser hvordan eleven synes særligt engageret og intenst optaget af et bevidsthedsarbejde om at løse en given problemstilling.

\section{Omverdensrelation}

Når eleven ud fra en forståelse af egen kulturel og faglig baggrund kan interagere i faglige, sociale, kulturelle og økonomiske sammenhænge og analysere disse for muligheder (Fonden for Entreprenørskab, 2016), er det et tegn på, at eleven er ved at udvikle kompetencer i relation til omverdenen, i sammenhæng til entreprenørskab.

Didaktiske markører for entreprenørskabsundervisning under dimensionen omverdensrelation er: At stimulere nysgerrighed og undren, at involvere aktuelle temaer, at perspektivere faglighed, viden og færdigheder, at involvere sociale, økonomiske og kulturelle kontekster, at sikre interaktion mellem individ, skole/institution og omverden, at opsøge viden og feedback fra omverden, at italesætte verden som mulighed, at invitere til refleksion $\mathrm{i}$ forhold til omverden (Didaktiske principper, Fonden for Entreprenørskab, 2016:28)

Billede 1, Didaktisk markør for inddragelse af omverdenen i entreprenørskabsundervisning: sikre interaktion mellem individ, skole/institution og omverden

En lærers fortælling om egne erfaringer fra praksis, giver eleverne en oplevelse af, at deres valg af uddannelse er det rigtige valg:

"Jeg synes, det er rart når [lærerens navn] er kommet med nogle af hendes egne oplevelser ude fra praksis [...] Det er sådan noget der, vi kommer ud til - eller kan komme ud til, hedder det" og "... jeg synes, det er det, der er med til at virke. Fremfor at man har et eller andet billede af hvad det er for en virkelighed, man kommer ud til. Det kan jeg godt lide"

Citatet viser, hvordan didaktisk brug af praksiserfaringer, skaber billeder for eleverne af hvad det for et arbejde, deres uddannelse leder frem til. Man kan måske endda sige, at brugen af praksiserfaringer situerer elevernes læring i et konkret arbejdsfelt og i specifikke relationer. Didaktisk etablering af samspil mellem elevens motivation og fremtidige arbejdssituation, ser ud til at påvirke læring positivt.

På EUD Merkantil har elevdeltagelse i konkurrencer sikret interaktion med omverdenen. Her tilkendegiver nogle elever klart, at konkurrenceelementet har givet dem større lyst og motivation til uddannelse. En elev synes for eksempel at det er hårdt at lære at lave resultatbudgetter, men når det opstår som krav for at kunne deltage i en konkurrence, siger han:

"... du skulle bare lære at lave de der budgetter. Du skulle bare lære det, der var nødvendigt. Hvis vi ikke lavede det kom vi ikke med til konkurrencen"

Nødvendighed ser ud til at fremme motivation og eksemplet viser, hvordan bevidst interaktion med omverden har betydning for elevernes læring. Eleverne motiveres af konkrete relationer, og motiveres til at lære i en forståelse, der emergerer, som del af interaktionen 
mellem elev og omverden. Eksemplet viser en elevs optagethed af at lære at lave budgetter, fordi det er nødvendigt at kunne mestre i en anden kontekst (en konkurrence), og idet eleven ønsker deltagelsen i konkurrencen, intensiveres optagetheden af at forbedre sin kunnen. Eksemplet kan ses som en ydre motiveret handling. Men uagtet hvorfra motivationen har sit udspring, synes elevens bevidsthedsarbejde på at forbedre sin kunnen (om at lave budgetter) at blive understøttet af, at læringen bliver meningsfuld for den enkelte elev. I eleverfaringerne af undervisningen er der overlap mellem princippet om undervisning, der sikrer interaktion med omverdenen, og undervisning, der søger viden og feedback fra omverdenen. Om det sidste siger en lærer, der har brugt konkurrence som arena for feedback, at konkurrencen gør, at eleverne føler at de bliver taget alvorligt af eksterne partnere. Det kan læses som endnu en understregning af at 'styrkelse' af læring er relationelt og organisering af læringsrelationer er en central didaktisk opgave.

Billede 2, Didaktisk markør for inddragelse af omverdenen i entreprenørskabsundervisning: sikre involvering af sociale, økonomiske og kulturelle kontekster

I et undervisningseksperiment arbejder to lærere fra en landbrugsskole med, at elevernes kendskab til målgrupper udvides. Eleverne skulle i to måneder arbejde projektbaseret omkring emnet 'Børn og unge'. Eleverne skulle udvælge og kontakte en repræsentant for målgruppen. Børn og unge som social kontekst for undervisningen var nyt. Eleverne oplevede at familier og venner i den anledning blev til netværk, som de kunne bruge til at arrangere en event, for eksempel et skoleklassebesøg på en gård. Didaktisk kontekstualisering (rekontekstualisering) af undervisningen gjorde, at nogle elever oplevede at have nye eller flere læringsressourcer (familie og venner).

På EUD Merkantil fandt eleverne i valgfaget 'Iværksætteri' frem til konkrete produkter, de ville udvikle, ved at bruge deres hverdagserfaringer. På den måde gjorde læreren eleverfaringer til læringsmiddel. Eleverne udviklede for eksempel en APP, der samler nyheder, fordi en af eleverne havde en erfaring med en far, der altid læste mange aviser. Andre eksempler er en APP til lægebookning, og en ny slags kodelås til døre på skolen. Eleverne kom fra ide til produkt vha. læreren og samarbejde med virksomheder. Nogle elever har solgt deres produkt til produktion, og siger omkring virksomhedsinddragende undervisning:

"Vi har valgt det ... det er federe at sige, man har valgfag, man tjener penge på, end hvis man har idræt. Der er så mange, der pjækker fra idræt". (elev EUD Merkantil)

På EUD Social og Sundhed har eleverne arbejdet med at skrive artikler om forskellige sociale målgrupper. Opgaven - at skrive en artikel - vender elevernes opmærksomhed ud fra skolen og ud til den eller de målgrupper, de senere vil møde i deres arbejde.

I ovenstående eksempler bliver det altså tydeligt, hvordan den praksisnære form for undervisning er motiverende for eleverne. Man kan sige, at den aktive interaktion med omverdenen, ser ud til at udvide elevers motivation og læring. Den læring, der foregår, ser ikke ud til at være privat (som når der individuelt lyttes eller læses) men at have en social karakter. Eksempler på dette er at få erfaringer med nødvendighed og taknemmelighed knyttet til læringssituationen og at være medskaber af den erfarede betydning af det lærte. Omverdensrelation-dimensionen bliver tydelig i elevernes læring, på den måde de både lærer et indhold, og samtidigt lærer om den betydning det har for andre mennesker. 
Billede 3, Didaktisk markør for inddragelse af omverdenen i entreprenørskabsundervisning: Invitere til refleksion i forhold til omverdenen

Eksempler på hvordan lærerne arbejder med at udvikle elevernes entreprenørielle kompetencer, ved at skabe undervisning, der inviterer til refleksion i forhold til omverdenen, findes blandt andet på EUD Social og Sundhed. En gruppe elever har som del af et innovationsprojekt delt kage ud til hjemløse på Københavns Hovedbanegård og på 'Mændenes hjem'. I denne undervisning oplevede eleverne at undervisning, der inkluderede besøg hos den gruppe af borgere som undervisningen handlede om og som de samtidig læste teorier om, gjorde det muligt for dem at afprøve teorier i virkeligheden. Eleverne kobler i deres fortælling om denne undervisning personlig motivation (lyst til at hjælpe) med det teoretiske indhold. Det kan ses som eksempel på, hvordan didaktisk brug af direkte møde med virkeligheden skaber lyst til læring.

Da en elev senere bliver spurgt til læreprocessen i forbindelse med projektet, fortæller han, at dét at møde virkeligheden, i form af de hjemløses glæde over kagerne, tilføjede en emotionel dimension til hans læring. Dertil styrker den emotionelle læring hans motivation for uddannelsen generelt.

Interviewer: Nu siger du, at du har lært noget, du har også følt noget, omkring hjemløse. Hvad betyder det for dig, at du lærer på den her måde i stedet for, at du måske skulle have læst det som en novelle i en bog, eller læst det som en artikel i en avis? Kan du prøve at sætte nogle ord på det?

Elev: Det giver så meget personligt, og så meget socialt.

Interviewer: Kan du prøve at sige noget om det personlige?

Elev: Altså, der er mange måder man kan blive pædagog på, f.eks. man kan tage gymnasievejen, hvor man bare læser en bog. Her er er vi jo ude med mennesker, vi giver rigtige mennesker kage, ude og snakke med rigtige mennesker. Vi får den her sociale, det kommer helt ind. Vi gør det man elsker, alle elsker, hele klassen elsker, alle her på skolen elsker, nemlig mennesker. Og det kan man ikke bare læse $i$ en bog.

Interviewer: Og det gor også, lyder det som om, at du bliver meget mere motiveret på den måde, og får det ind på en anden måde. Så sagde du også noget med det sociale, så du sagde både det her med at få lyst til at lave noget, men også noget med det sociale.

Elev: Som en klasse, når vi går ud og giver kage. F.eks. så holder vi jo sammen, vi snakker sammen, og vi gør det her arrangement med at give kage, sammen. Vi gik alle sammen rundt og gav kage, og vi blev alle sammen påvirket på den her måde, fordi det var et emne som vi ikke havde regnet med ville være så seriøst. Så vi blev også lidt chokerede over, at vi gjorde det, for det her er ikke bare en dukke, eller en eller anden fra klassen, det er ægte mennesker som ikke har det godt.

Eksemplet viser, hvordan et handlingsorienteret projekt forvandler mennesker i målgruppen for elevernes uddannelse fra objekter (sociologiske kategorier) til mennesker, og hvordan den konkrete erfaring af andres taknemmelighed påvirker læring. Samtidigt gjorde det, det muligt for eleverne at afprøve teorier af i virkeligheden. Eleverne kobler i deres fortælling om denne undervisning personlig motivation (lyst til at hjælpe) med det teoretiske indhold. Det kan ses som eksempel på hvordan didaktisk brug af direkte møde med virkeligheden skaber lyst til læring.

Endeligt illustrerer eksemplet, hvorledes fællesskaber og fælles optagethed af fælles temaer kan understøtte den enkelte elevs optagethed af at forbedre sin kunnen (om at være noget positivt for andre) - her tydeliggjort gennem det, at eleven ikke havde regnet med, at det ville blive så seriøst Derudover viser det - som ovenstående - at relationer og kontekst hvorunder handlingen demonstreres (gennem et elevfællesskab om at gøre noget godt for andre) synes at initiere en særlig intensitet og interesse for at lykkes og gøre det godt. 


\section{Personlig indstilling}

Når eleven kan overkomme ambivalens, usikkerhed og social kompleksitet, arbejde vedholdende, lære af andres og egne fejl samt foretage etiske vurderinger og refleksioner (Fonden for Entreprenørskab, 2016) er det et tegn på, at eleven er ved at udvikle sin personlige indstilling hen i mod troen på, at kunne agere $i$ verden og herigennem, at kunne realisere dromme og planer i sammenhæng til entreprenørskab. Personlig indstilling er de personlige og inter-subjektive ressourcer, som elever og studerende møder udfordringer og opgaver med.

Didaktiske markører for entreprenørskabsundervisning under dimensionen personlig indstilling: at sikre succesoplevelser, at stille tilpas udfordrende opgaver, at skabe rum for en anerkendende tilgang, at arbejde bevidst med usikkerhed, at arbejde med involvering og elevinddragelse, at understøtte og vejlede elever og studerende med feedback, at invitere til refleksion over personlige ressourcer og interesser (Didaktiske principper, Fonden for Entreprenørskab, 2016:28)

\section{Billede 1, Didaktisk markør for personlig indstilling i entreprenørskabsundervisning:} Sikre fokus på involvering og elevinddragelse

Der er i empirien eksempler på, at det kan virke stærkt motiverende for eleverne, at arbejde med problemstillinger de selv er optaget af, eller har haft en personlig oplevelse omkring, at det giver dem mod til at kaste sig ud i at skabe forandringer. Her er det en elev fra EUD Merkantil, der fortæller, hvordan hans erfaringer og interesser var drivkraft for gruppens projekt:

"Vores [ide] kom fra min personlige erfaring med at anskaffe et krybdyr... jeg stod i den situation, at den, som havde dem [krybdyrene] i butikken ikke havde plejet dem som de skulle - ikke nok C3 vitaminer og varme - metaboliske knogleskader - så det skal ikke ske igen. - Hvorfor ikke højteknologisk terrarium. Førte til at jeg kom til Young Enterprise. På den måde fik vi lavet... [ldeen var] at man aldrig skal opleve igen at miste noget, man holder af. Firmaet sælger. På top 25 i Young Enterprise." (elevinterview fra EUD Merkantil)

Citatet viser, at elevens personlige engagement i forhold til at afhjælpe et særligt problem med krybdyr, hjælper til at bringe hans faglige viden og færdigheder i spil på en ny måde, og hans engagement og interesse og personlige involvering i opgaven, må tillægges betydning i forhold til, hvor langt hans ide til firma er nået i en Young Enterprise konkurrence. Eksemplet viser også, hvordan en læreproces, der er båret af en personlig interesse, understøtter en særlig intensitet og optagethed af at forbedre sin kunnen - og det synes som, at denne optagethed understøtter en ihærdighed mod at nå et vellykket resultat.

En elev på en teknisk skole har en erfaring med, at undervisningen i entreprenørskab var involverende og inddragende, da den tog udgangspunkt i elevinteresser. En elev fortæller, hvordan hun kommer på nye idéer ved at tænke på sin hobby:

"I begyndelsen var det sådan forholdsvis svært for mig at finde ideer, men så tænkte jeg sådan lidt ud fra min egen hobby, så ... kom jeg jo videre derfra." (Elevinterview, Teknisk skole) 
En lærer fra EUD Social og Sundhed beskriver, hvad det kan betyde for eleverne, at de får mulighed for at tage udgangspunkt i deres interesser i læringssituationer. Han giver udtryk for, at det kan være motiverende for elever, som ellers ikke virker engagerede, fordi de får et andet forhold til undervisningen:

"Mange af dem, der ikke plejer at være så engagerede, de har virkelig følt, at det er deres eget, det her. Vi plejede bare at komme med noget materiale eller nogle ting og så skulle de lave det. Men lige pludselig så er de ligesom kommet over denne her mur med at sætte denne her tankegang i spil og så har de følt, at det er deres eget. Vi har bidt mærke i betydningen af, at det er noget de selv må vælge - eleverne siger selv, at det betyder meget, at de må beskæftige sig med noget der interesserer dem. Det har betydet meget for nogle af dem." (lærerinterview, EUD Social og Sundhed).

Undervisning, der inddrager eleverne med udgangspunkt i elevinteresser, skaber drivkraft for mange elever og kan være en rigtig god måde for eleven at få startet på noget, som kan udvikle sig fagligt. Også det forhold, at eleven selv må vælge og kan finde interessefællesskaber med andre elever, hvor de kan dele erfaringer og viden med andre elever, kan virke motiverende. Gennem brugen af det didaktiske princip, at tilrettelægge undervisning, der har fokus på involvering og elevinddragelse, viser empirien, at læreren har formået at skubbe til elevens motivation og læring, og at elevens kompetencer i forhold til personlig indstilling er blevet udviklet. Dette markeres i eksemplerne ved, at eleverne har øget troen på egne ressourcer og evne til at arbejde vedholdende med et projekt.

Billede 2, Didaktisk markør for personlig indstilling i entreprenørskabsundervisning: Arbejde med at understette og vejlede elever gennem feedback

Elever fra EUD Social og Sundhed har en erfaring med, at læreren var med til at understøtte og vejlede dem ved at følge eleverne fra sidelinjen og være klar til at tilføre nye og opfriskende perspektiver, når gruppen havde behov for det:

Elev: "Hun [læreren] skulle være lidt på sidelinjen, og hun skulle altid være klar hvis gruppen, eller andre grupper går i stå, så skulle hun komme ind og støtte os, give feedback, okay nu er I gået $i$ stå, hvad nu hvis I prøver lige at.... det var hun også rigtig god til -... tænk lige, - vend den lige om på en anden måde. Hver gang vi gjorde det, så fik vi en million nye tanker og ideer.

Interviewer: Så hun gav jer ikke nogen svar, hun gav jer mere en udfordring, eller et benspænd.

Elev: Ja, og det hjalp os rigtig meget hele vejen igennem" (Elevinterview, EUD Social og Sundhed).

En lærer fortæller, hvordan han har arbejdet med feedback i flere forskellige former, afhængigt af elevernes behov: 
"Altså. Det vi gør meget oppe hos os ..., det er jo meget afhængigt af gruppens behov, hvad det er for en feedback vi går ind og giver. For eksempel $i$ en gruppe med meget unge mennesker som er meget usikre, både på grund af, at de har psykosociale problematikker og samtidig usikre over for opgave, går jeg ind lytter. Jeg kan lytte mig til, at det er deres eget usikkerhedsmoment, og deres behov for at være trygge $i$ en ansættelse, der danner udgangspunkt for deres produkt. De vil lave en hotline, hvor man kan ringe ind. Da jeg får lyttet mig ind til deres behov, så kan jeg komme med konkret feed back og give konkrete bud. (lærerinterview, EUD Social og Sundhed).

God feedback og vejledning kan for eleverne både handle om at læreren er til stede og tilgængelig, når behovet opstår (timing) Men også om at læreren er i stand til at 'lytte sig ind til' gruppens behov og komme med det, som gruppen har brug for - både det de selv efterspørger og det de ikke selv ser.

Billede 3, Didaktisk markør for personlig indstilling i entreprenørskabsundervisning: sikre succesoplevelser og at stille tilpas udfordrende opgaver

En lærer fra EUD Social og Sundhed fortæller, hvad det betyder, at undervisningen er involverende ved, at den relaterer sig til noget fra elevernes erfaringsverden og at opgaven, der var stillet var tilpas udfordrende - og at det førte til, at en elev, som gik anderledes til undervisningen, end hun plejer, endte med at få en - måske uventet - succesoplevelse:

"Hun har egentlig været ret tilbagelænet, men i det sidste projekt, der valgte jeg, at de selv måtte bestemme, hvem de skulle være sammen med, og der kom hun så sammen med, en rigtig god fyr. ... De to de arbejder bare rigtig godt sammen og de lavede projekt om bander. De kommer begge to fra Husum, Tingbjerg, og har brødre, der har været bandemedlemmer og sådan nogle ting, så det var virkelig et emne, hvor de kunne komme op, der var noget de kunne relatere til, og de skar jo bare igennem. I fremlæggelsen lavede de det helt vilde. De havde været ude og kontakte organisationer. Pigen der, var virkelig glad. Det var rigtig godt for hende, at hun fik sådan en succes." (lærerinterview, EUD Social og Sundhed).

Eksemplet synes at vise, at eleven er i læring, idet hun er optaget af at forbedre sin kunnen (f.eks. lave et godt projekt og god fremlæggelse). Netop den personlige relation til emnet synes at dedikere elevernes engagement og intensivere arbejdet på at opnå et godt resultat. Også her ser vi et eksempel på en læreproces, der bæres af et særligt intensivt og engageret bevidsthedsarbejde. Og også her ser vi, hvorledes samarbejde med en anden elev synes ikke blot at understøtte, men også at være ret afgørende for at give arbejde værdi samt udholde og fastholde processen.

\section{Afrunding på første blik}

I de forudgående afsnit er der blevet præsenteret en række eksempler på undervisningseksperimenter omhandlende entreprenørskab, som lærerne har iværksat i deres almindelige undervisning, og det er blevet eksemplificeret, hvordan lærerne anvender forskellige didaktiske greb for at fremme elevernes entreprenørielle kompetencer i forhold til handling, kreativitet, omverdensrelation, og personlig indstilling. 
De didaktiske Billederne viser noget om bredden, hvilket vil sige forskelligheden i den måde lærerne arbejder med entreprenørskab på, og dybden, hvilket vil sige koblingen mellem undervisningseksperiment og elevernes læringsudbytte, ved at understøtte motivation og læring aktivt under entreprenørskabsforløbet.

På tværs af alle eksempler i de didaktiske billeder, ser og hører vi om lærere, der stiller spørgsmål til elever, fremfor at give dem svar. Lærerne leder eleverne frem mod svar, de end ikke selv kender.

Lærerne anvender didaktiske greb, der har fokus på at understøtte og vejlede elever gennem feedback, for derigennem at fremme entreprenørielle kompetencer.

Eksemplerne i de didaktiske billeder illustrerer, ikke blot om elevens motivation og læring påvirkes, men også hvordan motivation og læring påvirkes gennem undervisningseksperimenter omhandlende entreprenørskab. Den didaktiske tilrettelæggelse i undervisningseksperimenterne skaber mulighed for, at motivation og læring bliver gensidigt forstærkende, så elevens læringsudbytte forstærkes og beriges gennem en øget motivation - og samtidigt, at den didaktiske tilrettelæggelse i undervisningseksperimenterne skaber nye læringsmuligheder, som igen forstærker motivationen udtrykt som engagement og lyst til at udvikle videre.

På tværs af billederne kan vi se, at arbejdet med entreprenørskab, uanset hvor forskelligt det har fundet sted, har åbnet for nye læringsrelationer - og i forlængelse heraf også for nye erkendelsesmåder. Den måde, dimensionerne inddrages i elevopgaver eller elevaktiviteter, udvider simpelthen læringsindholdet. Med det menes, at eleverne ikke bare lærer mere, eller er mere motiverede, men at de lærer anderledes og herigennem ser ud til at have et øget læringsudbytte.

I arbejdet med at analysere hvordan og hvornår elevernes motivation og læring træder frem dukker der nogle tværgående tematikker op, så som betydningen af Lærerens rolle, relationer og samspil, mellem elever imellem, lærere og elever og omverdenen, samarbejdsformer af mere kollaborerende karakter, selvværd og selvtillid hos eleverne og større grad af fællesskab om opgaver, og inklusion af elever med faglige eller sociale udfordringer. Vi er nysgerrige og ønsker at forfølge de tværgående tematikker ved at undersøge om det er didaktiske forhold, som er særlige betydningsfulde for undervisning omhandlende entreprenørskab med henblik på, at udvikle elevernes entreprenørielle kompetencer.

\section{Andet blik - Didaktiske billeder på elevers deltagelsesmåder i undervisning gennem entreprenørskab}

Denne del af analysen, har til formål at åbne for fortællinger om elevernes deltagelsesmåder $\mathrm{i}$ entreprenørskabsundervisning på EUD - teknisk, social og sundhed og merkantil. Dette gør vi ved, at vi i billeder får indsigt $\mathrm{i}$, hvordan lærerne gennem undervisningseksperimenter omhandlende entreprenørskab, med didaktiske greb åbner for måder, hvorpå eleverne kan deltage aktivt og medskabende i undervisningen og deraf, hvad disse deltagelsesmuligheder kan sige i forhold til elevernes motivation og læring.

Som tidligere skrevet, er deltagelse et helt centralt element i den sociokulturelle læringsforståelse, som er analysens læringsafsæt. Her forstås læring netop som

- Situeret, grundlæggende social, distribueret og medieret,

- Omhandler deltagelse i praksisfællesskaber, 
- Erfares gennem handling og sker gennem en eksperimenterende tilgang.

Det vil sige, der er fokus på elevhandlinger som del af undervisnings- og læringsprocessen, snarere end præstationer ved undervisningens afslutning. Vi forstår deltagelse, som et tegn på, at eleverne er i proces med at udvikle entreprenørielle kompetencer, belyst gennem entreprenøriel adfærd knyttet til dimensionerne i entreprenørskabsundervisning. I den empiriske analyses andet blik, er det kontekstuelle og uddannelsesspecifikke i fokus i modsætning til første blik, hvor det er de didaktiske greb i sammenhæng til de fire dimensioner, som er i fokus. Vi har en forventning om, at ved at sætte det kontekstuelle og uddannelsesspecifikke som ramme om de didaktiske greb, får vi viden om, hvad der, ved entreprenørskab i erhvervsuddannelserne, åbner for deltagelsesmåder, som påvirker elevernes motivation og læring.

Vi har i det følgende valgt at opdele empirien i tre hovedområder inden for erhvervsuddannelserne,

- EUD Teknisk.

- EUD Social og Sundhed.

- EUD Merkantil.

Den empiriske analyses andet blik bygger på empiri indsamlet fra otte eksperimenter, fordelt på 8 forskellige uddannelsessteder, tre tekniske, to SOSU skoler og tre merkantile i efteråret 2016, og tre undervisningseksperimenter fra EUD social og sundhed forår 2016. Uddannelserne er udvalgt ud fra lærernes beskrivelse af deres undervisningseksperimenter. Der har i enkelte tilfælde været afvigelser mellem det eksperiment, som vi havde udvalgt til følgeforskning, og så det faktiske gennemførte eksperiment.

Inden for de tre overordnede uddannelsesområder indenfor EUD, er der ifølge den erhvervspædagogiske forsker Bill Lucas (2014) tre medier som er omdrejningspunkt for faglig forståelse og faglig udvikling. Det er fysiske materialer, mennesker og symboler. De knytter sig til kerneforståelsen og er i grove træk kendetegnet ved:

- EUD Teknisk: Her finder vi erhvervsuddannelser, der overvejende er orienteret mod arbejde med fysiske materialer, for eksempel: mure- vvs- elektriker og tømmerarbejde, tandteknik, mekanisk arbejde samt frisør- og make-uparbejde med mere.

- EUD Social og Sundhed: Denne gruppe erhvervsuddannelser, er overvejende orienteret mod arbejde med mennesker, for eksempel: socialt og pædagogisk arbejde, sundhedsarbejde med mere.

- EUD Merkantil: Denne type erhvervsuddannelser fokuserer på arbejde med symboler. Det er for eksempel: regnskabsarbejde. softwareudvikling, salg og handelsarbejde og servicearbejde med mere.

Men der er ifølge Bill Lucas flydende overgange mellem medierne for kernefaglig orientering og de tre typer af erhvervsuddannelser, og de lader sig ikke adskille så stringent som ovennævnte opdeling viser. Vi er inspireret af de tre medier som ifølge Bil Lucas rammesætter erhvervsuddannelserne og dermed kan ses som omdrejningspunkt for faglig forståelse og faglig udvikling. Medierne knytter sig til kernefagligheden og dermed har vi en forventning om, at medierne også kan virke som læring- og motivations drivere i sammenhæng til entreprenørskabsundervisning i erhvervsuddannelserne.

Under hvert område, er der valgt undervisningseksperimenter omhandlende entreprenørskab, til at belyse elevernes deltagelsesmåder i undervisningen i sammenhæng til uddannelsesretning og kontekst. 
Hvert erhvervsuddannelsesområde er bygget op omkring præsentationer af undervisningseksperimenter, tilhørerende billeder på elevernes deltagelsesmåder i entreprenørskabsundervisningen og de didaktiske greb, som læreren har gjort brug af for at åbne for elevernes deltagelsesmåder.

Først beskrives det overordnede eksperiment og lærerens intentioner hermed, dernæst beskrives en specifik undervisningssituation med fokus på de didaktiske greb, som er drivende for processen. Elevers erfaringer med deltagelse i eksperimentet beskrives dels gennem observation af måden, de deltager i undervisningen på Dels gennem lærernes observation og refleksioner over elevers deltagelse. Og endelig gennem elevudsagn, hvor elever selv beskriver deres aktivitet i undervisningen. Det er gennem beskrivelse og analyse af elevdeltagelse, at vi kan se på hvilken måde undervisning gennem entreprenørskab påvirker elevers motivation og læring.

\section{EUD Teknisk}

Inden for de tekniske erhvervsuddannelser er det, den fysiske materialitet (Lucas 2014) som ofte er centrum for kernefagligheden, og derfor bygger denne del af analysen på en antagelse om, at fagligt entreprenørskab i erhvervsuddannelserne ofte knytter sig til udvikling eller forbedringer med fysisk materialitet, som omdrejningspunkt for elevens udvikling af entreprenørielle kompetencer.

Det følgende baserer sig på observationer fra tre undervisningseksperimenter omhandlende entreprenørskab, samt interview med elever og lærere, der var involveret i disse forløb.

\section{Undervisningseksperiment 1: Mureruddannelsen, hovedforløb}

Undervisningseksperimentet omhandlende entreprenørskab på mureruddannelsen, er karakteriseret ved at arbejde med fagets læringsmål gennem entreprenørskab. Læreren har valgt at strukturere sit undervisningseksperiment efter eksperimenthjulet målrettet elever (Koch og Sørensen 2017), som han er blevet præsenteret for under sit diplomforløb i efterår 2016.

Undervisningseksperimentet foregår inden for faget 'valgfri specialisering' på hovedforløb 4, hvor eleverne er i gang med deres tredje år. Eleverne vælger selv, hvad for en slags murværk, de vil arbejde med inden for flisearbejde, murekonstruktioner, tag, restaurering og energi. Forløbet varer tre uger. I den første uge arbejder de ud fra egne idéer med at projektere og lave alle de udregninger, der skal til for, at de i løbet af de sidste to uger kan udføre deres individuelle projekter i værkstedet på skolen. Der er ti elever på holdet, som består af unge mænd mellem 18-42 (flest under 25 år). Et par af dem har svært ved at koncentrere sig, én er ordblind og har store faglige vanskeligheder, og der er én, der stammer. To af eleverne kommer fra Færøerne (hvor man ikke bygger med mursten), og en kommer fra Spanien (han har dog været i Danmark i mange år).

\section{Lærernes intentioner med undervisningseksperiment omhandlende entreprenørskab} Læreren på mureruddannelsen fortæller, at der inden for branchen er behov for håndværkere, som kan arbejde motiveret og selvstændigt. Der er brug for, at de ud fra kundens behov er $\mathrm{i}$ stand til at finde løsninger, og føre dem ud i praksis. Læreren ser entreprenørskabsundervisning som en god vej til at imødekomme branchens behov, ved at undervisningen retter sig mod, at eleven udvikler kreativitet, innovation og selvstændighed. Lærerens antagelse er, at eleverne opnår entreprenørielle kompetencer, ved at arbejde selvstændigt gennem faserne i eksperimenthjulet målrettet eleverne, med læreren som vejleder.

Entreprenørskabskompetencer på dimensioner som kreativitet, handling, omverdensforståelse og personlig indstilling, ser læreren på mureruddannelsen som noget, der udvikles bl.a. "når eleverne får deres ideer ud fra noget, de har set uden for skolens regi, og som de gerne selv vil 
afprøve. Og som de selv former i projekteringsdelen, hvor de sætter deres helt egne personlige præg på opgaven ud fra de love og regler (analyser), der vedrører faget" som han udtrykker det.

Murerlæreren betragter entreprenørskabsundervisning, som han også eksperimenterer med i andre sammenhænge, som noget helt andet end traditionel tavleundervisning med power point oplæg fra lærerens side. Med entreprenørskabsundervisning er det ikke læreren, som fortæller eleven, hvad han skal undersøge og udføre - og hvordan han skal gøre. Det er derimod eleven selv, som sætter sig for, hvad han vil undersøge og udføre - og hvordan han vil gøre. Eleven får også et andet forhold til undervisningen, når han arbejder med alle led i processen fra idé til udførsel.

I forhold til mureruddannelsen ser læreren det ikke som problem at nå faglige mål samtidigt med, at eleverne arbejder med entreprenørskabsprojekter. Tværtimod synes han, at eleverne lærer det faglige indhold (teori og metoder) netop fordi, det er en forudsætning for at kunne udføre projekterne. Læreren fortæller, at han giver faglige oplæg om morgenen, hvis der er behov, og fordi på det tidspunkt er eleverne mest friske. Han vil for eksempel holde et oplæg om 'Uværdi', fordi han kan se, at eleverne har brug for denne viden, og er parate til den nu, hvor de er kommet godt inde i deres entreprenørskabsprojekter.

Det er lærerens erfaring, at denne form for undervisning er god for alle elever på mureruddannelsen - også dem med forskellige slags udfordringer. Læreren fortæller, at selv "svage elever" viser stort engagement, når de arbejder ud fra egen interesse og opfattelse af opgaven, som de føler ejerskab for, fordi de selv har valgt den. Han oplever, at eleverne kan selv, når de får mulighed for det, og at de på den måde får mere ud af det. Der er flere, der "falder fra" ved tavleundervisning, hvor de keder sig. Når eleverne arbejder selvstændigt, har læreren en rolle som vejleder, hvor han følger deres faglige læreproces, ser hvilke vanskeligheder, de støder ind i, og giver dem feedback og det faglige input, de har behov for - enten individuelt eller fælles. Denne lærerrolle gør det muligt for læreren, at støtte og stilladsere den enkelte elevs læring.

\section{Undervisningseksperiment 2: Anlægsgartneruddannelsen, GF 2, internati- onal klasse}

Undervisningseksperimentet er på uddannelsen til anlægsgartner, og er karakteriseret ved at arbejde med fagets læringsmål gennem entreprenørskab. Undervisningseksperimentet foregår inden for faget 'anlægsteknik' på GF 2/international, som er et 10 ugers forløb, for i dette tilfælde ungarske elever. Undervisningseksperimentet forløber over to uger, og foregår i en udvekslingsklasse, som består af 20 ungarske elever, 8 piger og 12 drenge fra $18-22$ år. Læreren har valgt at strukturere sit entreprenørskabsforløb efter en procesmodel, der rammesætter en innovationsproces kaldet Innovationstrappen (Koch og Sørensen 2010). Det er lærerens vurdering, at det muligvis er de fagligt stærkeste elever, som har fået mulighed for at komme på uddannelsen i Danmark. Eleverne har den udfordring, at de aldrig før har prøvet at arbejde med fagets mål gennem entreprenørskab, og at denne form for entreprenørskabsundervisning er helt ny for dem. Ifølge læreren er det meget fremmed for dem og grænseoverskridende, at de skal stole på deres egne ideer og arbejde så selvstændigt og kreativt. Der er også sproglige udfordringer for eleverne, som må prøve sig frem på engelsk, ofte ved hjælp af google-translate. Entreprenørskabsprojektet er tilrettelagt med afsæt i at eleverne fortæller om en række anlægstekniske problemer, som de møder i deres hverdag, for derefter at arbejde med et konkret projekt med relevante problemer, som de skal løse.

\section{Lærernes intentioner med undervisningseksperiment omhandlende entreprenørskab}

Læreren fra gartneruddannelsen forklarer, at jobbet som anlægsgartner ofte indebærer kontakt til kunder, som stiller krav til den ansattes kreativitet og evne til at løse problemer. Han ønsker derfor med entreprenørskabsundervisning, at eleverne bliver i stand til at honorere disse krav. Han har en antagelse om, at de ungarske elever har behov for at få udfordret deres kulturelle 
og faglige forståelser, for at kunne udvikle sig personligt og fagligt. Hans fokus er at give eleverne erfaring med, at tænke og handle entreprenant inden for deres fag (anlægsteknik som anlægsgartner) - "så de kan blive fremtidens udviklere og produktudviklere og måske også tjene gode penge " som læreren udtrykker det.

Læreren giver udtryk for, at der er nogle elever, som han har særlig fokus på, fordi de har behov for ekstra støtte og opmuntring, til at begynde at arbejde selvstændigt med egne idéer. Endvidere fortæller han, om de forandringer han har oplevet hos eleverne:

"Jeg kan se, at de projekter [...] har udviklet helt vildt meget i dem. [...] Den første opgave jeg gav dem, det var at lave en lille firkantet terrasse, og det kunne de nærmest ikke. Og så til det sidste projekt, hvor de selv skulle opfinde en lejrplads- og der kom fem forskellige lejrpladser. På den måde har jeg kunnet se deres udvikling, og jeg har også kunnet se det i måden, de taler til mig på, og hvordan de er løsnet lidt op" (Lærerinterview, Gartneruddannelse).

Det er denne lærers erfaring, at disse forandringer kommer af, at eleverne "har fået lov til at gøre nogle ting, de har fået frihed" (Lærerinterview, Gartneruddannelse).

\section{Undervisningseksperiment 3: Automatik og procesuddannelse, $\mathrm{H} 1$}

Undervisningseksperimentet er på uddannelsen til automatiktekniker og er lige som de to foregående karakteriseret ved at arbejde med fagets læringsmål gennem entreprenørskab. På holdet er der 19 elever i alderen 20 - 45 år. Lærerne vurderer, at de fagligt befinder sig på et begynderniveau her i starten af hovedforløbet, og at de er "relativt stærke elever". Der er 4 elever, som følges af SKP, som læreren siger "ikke er udsatte - de er praktisk svage, og i længden bliver det til en teoretisk svaghed". Undervisningseksperimentet foregår i faget styringsteknik, og undervisningseksperimentet omhandlende entreprenørskab forløber i en uge. Eleverne har lavet en praktisk opgave, hvor de skal lave et styringssystem. Over tre dage skal eleverne udvikle en motor og en timer, der kan styre motoren og indlejre en pause. Eleverne udvikler i makkerskaber individuelle styringssystemer. Arbejdet forløber i tre faser: a) først tegner de et system på computer (ca. den første dag) og b) dernæst bygger de en motor, som de til sidst c) skal forsvare.

\section{Lærernes intentioner med undervisningseksperiment omhandlende entreprenør- skab}

Automatikteknikeren arbejder på tværs af elektriker-, maskinarbejder- og smedefagene, og det er denne fagperson, der fejlfinder og reparerer elektromotorer, relæer og elektrisk udstyr på maskiner og anlæg. Det er et specialefag, eleverne kan vælge på hovedforløbet. Uddannelsen er målrettet elever, der brænder for at opstille og vedligeholde automatiske maskiner, som for eksempel elevatorer og højteknologisk udstyr brugt i industrien. Automatik- og procesteknikere står for opbygning, indkøring og vedligeholdelse af automatiske anlæg, der kan være hydraulisk (væsketryk), pneumatisk (lufttryk) eller elektroniske styret. (jf. TECs hjemmeside, automatik og procesuddannelsen). Lærerens intentioner er, at eleverne gennem refleksiv praksis, selv skal evaluere med produktets kvalitet for øje, i stedet for at læreren vurderer, om det de har lavet er godt eller skidt. Det foregår ved, at én tomandsgruppe evaluerer en anden tomandsgruppe med kun lidt indgriben fra lærerne. Læreren ønsker, at udvikle elevernes kritiske sans ved, at de skal holde fokus på opgaven, og lære betydningen af konstruktiv feedback og formidling i sammenhæng til udvikling og kvalitetssikring. Læreren ønsker, at løbende evaluering er med til at udvikle mod hos eleverne til at give feedback uden fokus på, at det er klassekammeraters opgaver og produkter, der skal gives feedback på i forhold til fejlfinding. Lærerens intentioner med evaluering er, at det i højere grad er eleverne, der har kontrol over, hvem der siger hvad, hvornår og der igennem opnå mere motivation og læring end hvis det, som det ofte er, læreren der udstik- 
ker rammerne. Lærerens intention er også, at give eleverne mulighed for at arbejde eksperimenterende med teknisk udvikling dog begrænset af, at lærerne har udarbejdet materialekassen, fordi det er i starten af eleverne hovedforløb. Slutteligt ønsker læreren, at undervisningseksperimentet kan være med til at give eleverne en praktisk oplevelse af mestring i forhold til fejlfinding.

\section{Didaktiske billeder på elevernes deltagelsesmåder}

Dette afsnit vil, i forlængelse af ovenstående tre undervisningseksperimenter, belyse i billeder, hvilke didaktiske greb som ser ud til, at åbne for elevernes deltagelse i undervisning gennem entreprenørskab i teknisk EUD, og dermed vurderes at have betydning for elevernes motivation og læring. Hvert billede indledes med en didaktisk markør for entreprenørskabsundervisning, hvilket betyder, at markøren knytter sig til didaktiske greb af betydning for, at eleverne udvikler entreprenørielle kompetencer. Disse billeder er fra observationer og interviews med fokus på, hvilke muligheder eleverne har for at deltage i eksperimentets undervisning.

\section{Billede 1, Didaktisk markør for deltagelsesmåder i entreprenørskabsundervisning:} Fordybelse $i$ egne interesser og selvstyrede projekter

Eleverne på mureruddannelsen sidder ved hver deres computer, fordybet i eget projekt. Der er en stille og rolig stemning i lokalet, og det virker til, at alle eleverne arbejder engageret i deres eget projekt. De har startet dagen med et kort fælles oplæg fra læreren og arbejder herefter på denne måde hele dagen - frem til kl. 15 kun afbrudt af en frokostpause på en halv time, hvorefter de hurtigt genoptager arbejdet. Stemningen dagen igennem er præget af arbejdsomhed og iver efter at fordybe sig i eget projekt. Det ser ikke ud til, at de bruger tid på at gå ud på Facebook, eller lave andet end det fagrelevante i forhold til deres projekter (fra observationsnoter). Nogle af eleverne giver i interviews udtryk for, at de er glade for, at de har fået idéerne selv til, hvad de ville arbejde med. Som en af dem siger: "Man vælger helt frit selv, og det er det, jeg synes der er det fede ved det her".

Et tilsvarende billede på at arbejde med selvstyrende projekter ud fra egne interesser, ser vi på gartneruddannelsen, hvor eleverne arbejder i tremandsgrupper. En gruppe vil udvikle en APP til pædagoger, så børn kan identificere giftige planter. En anden gruppe vil finde løsninger på, hvad man kan gøre ved høj vandstand, og hvordan man kan udnytte det i stedet for, at det er et problem. En gruppe vil udvikle en prototype på kundemateriale/manual i forbindelse med anlægsprojekter. En anden gruppe igen vil udvikle en kampagne, så fordomme overfor 'det grønne arbejdsområde' får modspil - bedre image. Endelig er der en gruppe, som vil lave en PowerPoint præsentation om streetart, som kan gøre Budapest mere grøn og spændende (fra observationsnoter). Eleverne har fået undervisning og input undervejs, men som læreren fortæller i et interview: "Det er en meget fri opgave". Læreren siger også, at "de er meget selvdisciplinerede, det var nok ikke gået i en dansk klasse. De arbejder virkelig i grupperne".

I interviewene fortæller eleverne, at det har betydning for dem, at de kan arbejde med et indhold, som giver mening. For nogle hænger det sammen med, at de véd, hvad de vil med uddannelsen. Derfor, siger de, er de ikke faldet fra som så mange andre, som gik ind til grundforløbet uden at vide, hvad de ville med uddannelsen.

Vi ser i dette billede, hvordan fordybelse i egne interesser og selvstyrende projekter, er med til at skabe fagligt engagement og mening for eleverne. Det ser ud til at have betydning for eleverne, at de deltager aktivt og tager ansvar i deres uddannelse i sammenhæng til deres 
lyst til at blive i uddannelse. Det at anvende faglig viden og færdigheder i relation til fremtidig arbejdsliv og med blik for autentiske kontekster ser ud til at engagere eleverne. Deres koncentration og vedholdende arbejdsomhed tyder på, at de er motiveret, og vi tolker det som tegn på, at de didaktiske greb som læreren har anvendt i deres eksperimenter åbner for både kreativitet, og et handleberedskab hos eleverne og er med til at fremme elevernes læring.

Billede 2, Didaktisk markør for deltagelsesmåder i entreprenørskabsundervisning: Faglig sparing mellem larer og elev som driver for næste skridt

Mens murereleverne arbejder med projektering og udarbejdelse af arbejdsplaner, herunder udregning af omkostninger til materialer, dukker der faglige problemer op for dem, som de beder læreren om at hjælpe med. Samspillet mellem eleverne og læreren virker ubesværet og lige til - i øjenhøjde. De faglige problemerne drejer sig f.eks. om forståelse for, hvordan tegneprogrammet virker, hvordan udregninger foretages (fra observationsnoter).

Enkelte elever lufter frustrationer, når de løber ind i vanskeligheder, men det går hurtigt over, når de får hjælp til at komme videre. En elev fortæller for eksempel, at det er rigtig svært med tegneprogrammet. "Jeg hader det. "Men han siger, at han er glad for, at han får den hjælp, han har brug for - ellers kunne han ikke klare det (fra observationsnoter).

I et interview fortæller en elev, at det virker godt, at lærerne er gode til at " [...] komme ned og hjælpe hvis man ikke forstår det. De er her jo altid hvis man ikke kan forstå det. For eksempel i tirsdags i sidste uge, der fik vi en gennemgang oppe ved tavlen og de [lærerne]står og fortæller og vi må stille spørgsmål og det hele. Og så siger de 'nu skal I i gang med at tænke nogle ideer og lave nogle skitser på det her. Og så giver de lige nogle gode [faglige] råd, og er der noget, man ikke forstår i teksterne, så kommer de lige ned og forklarer. For det er jo heller ikke alt jeg forstår inden for murerjargonen. Der er nogle ord, hvor man lige skal have vendt og drejet. Det synes jeg de har været gode til også. Altså, jeg kan godt lide denne her måde at gøre det på”.

Det ser ud til at være afgørende, at læreren er tilgængelig, som udtrykt af en murerelev i et interview:

"Altså du skal jo kunne gøre nogle ting selv og træffe dine egne valg, hvordan du gør det, og du skal stå ved dine bes/utninger. Jeg laver det her murværk nu, og jeg gør det sådan og sådan. Det gode det er så, at lærerne altid er der til at sporge, de kommer ikke rundt og ser, det skal man selv tage ansvar for. 'Jeg vil gerne have hjælp, for jeg er lidt i tvivl om det her'. Du har meget mere 'det er mig, der står for det, det er mig, der vælger hvad for noget materiale jeg vil have, det er mig, der vælger, hvordan det skal se ud', og så kan vi spørge dem til råds, for vi er stadig lidt uerfarne i det, så jeg synes, vi får meget ud af det \{...\}".

En anden elev fortæller i et interview, at han kan lide, at lærerne kommer med fælles oplæg i passende mængder og på de rigtige tidspunkter i forhold til deres projekter:[...] hvis vi er begyndt at mure noget, og vi alle sammen er lige ved at skulle gå i gang med tage, så kommer der et oplæg om tagkonstruktionen. Så vi ikke får det hele på én gang, så vi ikke bliver bombarderet med viden, for så har du jo glemt det om tre uger". 
Også i dette eksempel ser vi, at det har en betydning for eleverne, at læreren er tilgængelig og følger tæt deres læreproces ved at sætte ind med inspiration og hjælp lige præcis, når behovet melder sig.

Ligeledes pointerer elever på automatikteknikeruddannelsen, at det betyder noget for dem, at læreren er til stede og kan hjælpe dem: "Hvor læreren også er der, så man kan sige: 'Hey, jeg sidder fast her - kan du lige' og så videre. Men bare det, at vi selv får lov til at prøve. At de giver os noget information og så: 'Prøv at lege lidt med det'. Og så finder jeg ud af det".

I dette billede ser vi betydningen af den erhvervsfaglige underviser. Læreren bliver rollemodel for en murer, og bringer med sin fagfaglige erfaring viden autenticitet og omverden ind $i$ klasserummet, og bryder med den almindelige lærer og elevrelation, hvor læreren ofte er den udfarende. Praksisbaseret læring (Hersom 2017) er i centrum, og der er fokus på, at eleven skal dannes til at skabe praksis og relationen mellem lærer og elev får nærmest karakter af et praksisfællesskab med murerfaget og elevens projekt som omdrejningspunkt.

Billede 3, Didaktisk markør for deltagelsesmåder i entreprenørskabsundervisning: Videndeling og feedback eleverne imellem

Af og til henvender en murerelev sig til en anden elev, for at drøfte et fagligt spørgsmål eller spørge til, hvordan den anden har løst et problem. Eleverne virker åbne over for at hjælpe hinanden, og det ser ud til, at de går seriøst og engagerede ind $\mathrm{i}$ hinandens faglige udfordringer. På et tidspunkt er der én, som beder sidemanden om at kigge på hans skærm: "måske er jeg blind, jeg kan ikke finde ud af det". Den anden kan heller ikke finde ud af det, så han spørger en tredje, som ser ud til at kunne hjælpe. (fra observationsnoter).

Vi ser her, hvordan eleverne udnytter de muligheder de har for at trække på hinanden samtidig med, at de arbejder med individuelle projekter. Det ser altså ud til, at det styrende er deres egne interesser - men at det også giver mening for dem at hjælpe hinanden, når der er brug for det.

På gartneruddannelsen, hvor eleverne arbejder i grupper, har det ligeledes betydning for eleverne, at de kan arbejde sammen, men også at de kan trække på hinanden på holdet. Grupperne vælger at blive siddende inde i klassen. Læreren forklarer: "Jo, jeg har opfordret dem mange gange [til at arbejde andre steder] - de vil helst være sammen alle sammen, jeg kan ikke rigtig få dem til at forstå, at det er helt ok og har vist dem, hvor de kan gå hen". Eleverne sidder i klasselokalet hele dagen, hvor de arbejder på computer og taler ungarsk med hinanden. Det virker som om, de bliver fremskyndet til at samarbejde, når læreren ikke altid er til stede: "It's good without the teacher - we help each other!" (fra observationsnoter).

Ligeledes betyder det noget for eleverne på automatikteknikuddannelsen, at undervisningen giver mulighed for, at de kan trække på hinanden: 
"Jeg tror også, det er meget vigtigt hvilken klasse man kommer ind i. Jeg synes, vi er heldige med en god klasse, hvor folk er gode til at hjælpe hinanden på kryds og tværs. Og vi er jo en hel masse, som har en masse forskellig viden. Og det er bare svært at vide det hele, så det gælder også om at være god til at hjælpe hinanden på kryds og tværs, for at man kan tage lidt. Og det har man jo muligheden for, når man kører det lidt mere selvstændigt og opsøger information - kontra at der bare er en, der står og siger det hele" (Elevinterview, automatikuddannelse).

På automatikteknikuddannelsen ser vi et eksempel på en særlig form for samarbejde, hvor eleverne giver hinanden feedback således, at én gruppe hører meldingerne fra eleverne i en anden gruppe. Lærerne supplerer med spørgsmål og kommentarer. Der er to grupper ad gangen, som giver hinanden feedback.

I efterfølgende elevinterviews fortæller eleverne, hvordan de oplevede at evaluere hinanden. Når en elev bliver spurgt, hvad han lærer af at modtage feedback fra andre elever siger han:

"Jamen det er jo andres måde at gøre det på. Nye måder at se tingene på: 'Nå okay du kunne også gøre det sådan her i stedet for'. Vi har måske været låst med: 'Okay vi gør det sådan her', men det åbner jo muligheder op for at gøre det på andre måde. Det gør jo bare, at man får en bredere indsigt $i$, hvordan man kan gøre de forskellige ting. Så på den måde synes jeg, det er godt" (Elevinterview, automatikuddannelse).

Dette billede viser, hvordan læringsmiljøet er åbent, arbejdsomt og præget af faglig sparring eleverne imellem. De er fagligt engageret i deres projekter, og videndelingen får karakter af, at være styret af behov for input. Læringsmiljøet bærer præg af faglig nysgerrighed og et stort ønske om at dele viden eleverne i mellem, hvilket vidner om læring. De mange forskellige projekter giver eleverne mulighed for at anvende deres viden og færdigheder i forskellige kontekster, og det er tydeligt, at eleverne tager et ansvar for, at skabe et åbent læringsmiljø, hvor spørgsmål er velkomne. At eleverne arbejder med åbne opgaver, som samtidig er rammesat af læringsmål, ser ud til at være medskabende til det engagerede læringsmiljø. Lærerrollen er støttende og i øjenhøjde. Det er interessant, at se, at eleverne fra gartneruddannelsen helst vil være i samme lokale. Læreren ser det som et udtryk for tryghed, men det er nok snarere et udtryk for, at det giver mening at arbejde med skabende aktiviteter i fællesskab og de har brug for at skabe det faglige miljø sammen. Vi ser her hvordan de anvender deres indbyrdes relationer, og inddrager hinanden i deres projekter, hvilket understøtter deres kreativitet og handleberedskab. Elevernes refleksioner over feedback- former, er ret sigende for, hvad det kan åbne for af læring og stimulere til at tænke i nye muligheder. 


\section{Billede 4, Didaktisk markør for deltagelsesmåder i entreprenørskabsundervisning:}

Erfaring med fagets udøvelse

De fleste af eleverne på mureruddannelsen virker glade for og stolte over deres projekter. Under et interview viser én af eleverne uopfordret et billede på sin telefon af en mur, som han har lavet med kulørte fliser i form af Skagen. Han har på et aftenhold på skolen for "nørder" fået mod til at gå videre med at dyrke sin interesse for flisearbejde. Senere viser han stolt sit projekt på sin computerskærm og foreslår, at jeg kigger ud på værkstedet, hvor hans flisearbejde (som han laver på aftenholdet) er i gang (fra observationsnoter).

"Jeg kan lidt noget andet end de andre kan, som sådan. Eleven fortæller, at selvom han er træt efter en lang skoledag, så er det vigtigt for ham at deltage på aften kurset. Det udtrykkes ved, at han siger, at det 'godt kan være lidt træls' efter en hård dag på arbejde ... så må man bide det i sig... " (Elevinterview, Mureruddannelse)

For denne murerelev har det betydning, at han kan trække på sin særlige interesse for flisearbejde. Han fortæller i et interview, at han blev inviteret til et særligt 'nørde' aftenkursus om fliser af sin lærer, og eleven begrunder sit valg af 'fliser' ved, at han gennem dette kursus har erhvervet sig en særlig kompetence på området, hvor han kan løse specielle og vanskelige/dyre opgaver, som andre elever ikke umiddelbart kan.

Som vi ser i det følgende eksempel, har det i det hele taget betydning for eleverne, at de har mulighed for at se koblingen til den praktiske udøvelse af faget. En af eleverne på mureruddannelsen fortæller for eksempel i et interview, at han glæder sig til at blive færdiguddannet. Han oplever, at entreprenørskabsundervisningen giver ham noget i forhold til at blive selvstændig. Han siger, at han vil kunne få gavn af entreprenørskabshjulet, fordi fremgangsmåden i processen har lært ham at arbejde struktureret. Han mener, at det kan hjælpe alle eleverne, og hans makker samtykker ved at sige, at han også kan bruge det selv om, han ikke ved, om han skal være selvstændig.

Den ene af de to elever siger, at han synes entreprenørskabsundervisningen har givet ham noget, fordi lærerne "gerne vil have at man selv gør noget, at man selv søger informationen i stedet for, at man bare får det smidt det hele i hovedet" (Elevinterview, Mureruddannelse).

Murereleverne arbejder på forskellige faglige niveauer med deres projekter. Et par elever fortæller for eksempel knapt så stolt om deres projekter. Begge siger, at de vælger "det sikre". De er allerede efter tre ud af de fem dage, som er afsat til det, næsten færdige. De synes ikke, at de er "så kreative", men vil gerne være det til svendeprøven, for ikke at fremstå som dem med de kedeligste projekter. (fra observationsnoter)

En murerelev forklarede i et interview, at han 'er blevet til noget nu', og at han får et selvtillidsboost hver eneste gang, han har været på et praktikophold, fordi han kan komme ud og vise, hvad man har lært i skolen og bruge det i det virkelige liv. 
Dette kan være et eksempel på, hvordan det, at han kan noget særligt, som han har haft mulighed for at dyrke på skolen, understøtter hans oplevelse mestring gennem værdsættelse fra andre og samtidig hans egen vurdering af sine kompetencer.

Billedet her illustrerer, hvordan det er den fysiske materialitet, i de tekniske uddannelser f.eks. flisearbejde, som er omdrejningspunkt for elevernes engagement og lyst til at gå længere for at opnå, et for dem tilfredsstillende resultat. Som eksempel på det modsatte ser vi i situationen, hvor eleverne ikke er helt så stolte over deres faglige resultat med deres mureprojekt. De erkender, gennem refleksion, at det indbefatter foretagsomhed, engagement, kreativitet og flid, hvis de skal nå længere og mere i dybden med deres mureprojekter. Dette kan ses som et tegn på, at deres personlige indstilling til arbejdet med deres projektet er under bearbejdning, og at de nu ønsker, at deres afsluttende svendeprøve skal skille sig ud fra mængden og ikke være et kedelig og almindeligt projekt, som det de har fremstillet her. Læreren kan måske gøre en forskel for elever som dem, ved at organisere små grupper, der arbejder mere kollaborativt om opgaver i deres projekter. Og at læreren i højere grad skubber eleverne, og opfordrer dem til at kommer længere med deres projekter, og kaste sig ud på usikkert vand. Eleven, der er engageret i flisearbejde, viser hvor langt man kan komme gennem flid og motivation. Gennem didaktiske greb som at stille udfordrende opgaver, have en anerkendende og støttende rolle kan læreren være med til at sikre, at eleven får succesoplevelser, der gør, at han under sin uddannelse nu drømmer om, at gøre en forskel. Billedet viser også, hvordan elever ved hjælp af entreprenørskabshjulet har fået en ramme og indsigt til at strukturere en entreprenørskabsproces omkring et fagfagligt projekt, og at dette har bragt indsigter og drømme frem hos eleven, som at blive selvstændig og starte noget op selv.

\section{Opsamlende}

Opsamlende ser vi, at de tre undervisningseksperimenter udtrykt i ovenstående billeder inden for Teknisk EUD, fortæller om hvad entreprenørskab kan få af betydning i sammenhæng til elevernes erhvervsfaglige udvikling. Vi ser, at entreprenørskabsprojekter og faglig videndeling og sparring er med til at motivere og engagere eleverne i at tænke nyt og gå mere undersøgende til værks, og derigennem få mere handlingsrettede erfaringer med den faglige materialitet, som er omdrejningspunkt for deres uddannelse. Eleverne indtager nye roller som afspejler, at de har ansvar for at samle og bearbejde viden og erfaringer i relation til deres projekter. Lærerne er alle optaget af, at undervisning gennem entreprenørskab er med til at fremme kompetencer hos eleverne, som de (lærerne) mener, at brancherne har brug for. De didaktiske greb som lærerne anvender for at støtte dette er: Feedback, samspil eleverne imellem uanset hvilke udfordringer eleverne måtte have, en lærerrolle i øjenhøjde, åbne læringsmiljøer med klar faglig orientering, samt inddragelse af omverdenen. Billederne viser tydeligt, at elevernes faglige identitet er under konstruktion, og de motiveres gennem praksislæring, der giver mulighed for at skabe eller medskabe praksis. Når deres projekter baserer sig på en praksis ser vi tydeligt, at det øger relevansen og meningen med projekterne for eleverne, og dermed fremmer det deres motivation og læring

\section{EUD Social og sundhed}

I fortællingerne om elevernes deltagelsesmåder i entreprenørskabsundervisning på EUD - social og sundhed, er det overvejende mennesker, som er omdrejningspunkt eller medie for undervisningen på uddannelsesområdet (Lucas, 2014). Mennesker, og deres levede liv, er i centrum for forskellige faglige indhold og tilrettelæggelser. Det betyder, at mennesker som medie kan forventes, at have en grundlæggende betydning for elevernes motivation, engagement og lyst til deltagelse i deres uddannelsen En elev udtrykker sin uddannelsesmotivation således: 
"Jeg har siden jeg var fem år, tror jeg, vidst at jeg gerne ville arbejde med børn. Lige siden mor tog mig med ud på hendes arbejdsplads, hvor hun er pædagogmedhjæ/per. Så det var en super god måde at forfølge den drøm. Jeg kom på grundforløb, og så blev jeg helt bidt af det der med måden at undervise på, og måden med at lege sig til læringen. Og lave så mange anderledes ting" (elevinterview, EUD social og sundhed).

En anden elev samstemmer:

"Jeg har altid godt kunne lide at have med born at gore og jeg synes det var rigtig spændende. Og så kunne jeg godt lide, at denne her skole, den var mere, hvor man fik lov til at komme ud og prøve tingene, frem for kun at sidde og lave teori, som jeg har hørt det på de andre skoler. Det ville jeg ikke.

Forventningen er også, at det har en afsmittende effekt på den entreprenørskabsdidaktik, der skabes gennem de undervisningseksperimenter, som lærerne gennemfører. De enkelte billeder belyser altså entreprenørskabsdidaktik som det tager sig ud, når uddannelsens medie er mennesker og fokus er elevernes deltagelsesmåder i undervisningen. En lærer udtrykker, hvordan mediet mennesker påvirket elevernes engagement for- og lyst til uddannelse, og til spørgsmålet om, hvilke udfordringer eleverne har, fortæller han, at eleverne brænder for faget og udtrykker det sådan her:

"De [eleverne] har et ret stort drive i forhold til, at de ved, at det er noget, de gerne vil. De vil gerne tage vare på andre mennesker, og de vil gerne yde omsorg og nærvær for andre mennesker. Og det er det, de brænder for og går ind og arbejder med i undervisningen" (Lærerinterview, EUD social og sundhed).

Det er konkrete observationer fra fire undervisningseksperimenter om udvikling af entreprenørskabsundervisning, og interview med elever og lærere fra fem forskellige undervisningseksperimenter, der bredt dækker social og sundhedsuddannelserne gennem indtryk fra GF1 og GF2 plejer og assistenter og hovedforløb PAU. Datamaterialet er indsamlet både under pilot et og pilot to af den nye efteruddannelse.

\section{Fælles for lærernes intentioner med deres undervisningseksperimenter omhandlende entreprenørskab}

De fire lærere i nedenstående eksempler, ønsker med deres undervisningseksperimenter, at fremme elevernes entreprenørielle kompetencer og entreprenante mindset. De fortæller, at de i forvejen arbejder innovativt og med værdiskabelse, omverden og udvikling af personlig indstilling i deres undervisning. Men at de med deres undervisningseksperimenter får mulighed for at skærpe de didaktiske greb og arbejde mere udforskende om, hvad der gør entreprenørskab og dermed fremmer elevernes muligheder for at udvikle et mere entreprenant mindset.

Alle de adspurgte undervisere på EUD Social og Sundhed fortæller, at deres overordnede didaktiske overvejelser handler om, at de forestiller sig, at elevernes deltagelse i entreprenante læringsforløb udvikler eleverne til at blive mere frie, kreative og entreprenant tænkende og handlende i forhold til, at de kan skabe social og kulturel værdi for institutioner.

Et yderligere fælles træk for samtlige fire undervisningseksperimenter omhandlende entreprenørskab er, at alle lærerne på social og sundhedsuddannelserne fortæller, at de har tilrettelagt undervisningen som tværfaglige temaer eller projekter, hvor de arbejder med opnåelsen af eksisterende læringsmål gennem entreprenørskab. Det tværfaglige er med til at tone traditionelt set 
mere skolastiske fag til projektforløb med autentiske opgaver og udfordringer, der relaterer sig til virkelig arbejdspraksis gennem inddragelse af institutioner og professionelle fra praksis". De tværfaglige og praksisorienterede forløb kan siges, at være et signatur-pædagogisk (Lucas 2014) træk for entreprenørskab i EUD social og Sundheds uddannelserne, med værdiskabelse omkring forhold for mennesker og det levede liv, som forpligtende mellemværende mellem uddannelse og praksis.

\section{Undervisningseksperiment 1: Social og Sundhed, Hovedforløb, PAU}

På EUD Social og Sundhed, Hovedforløb på Pædagogisk assistent uddannelsen PAU, har eleverne arbejdet med et tværfagligt innovationsprojekt - " den ideelle institution". De oprindelige læringsmål for de fag, der bruges til at designe forløbet, er indlejret i det tværfaglige projekt. Der er to lærere, som er ansvarlige for gennemførelsen af forløbet. Eleverne har været i gang med deres uddannelse i et år, og de er dermed halvvejs i deres uddannelse. Der er ca. 25 elever i alt fordelt i fire grupper, alderen er mellem 18-30 år. Elevernes praktik er afsæt for, at de kan få idéer til " den ideelle institution". Eleverne er alene i praktik, og de er lige kommet i nye grupper. De er delt ind efter institutionstype i praktikken. Under entreprenørskabsforløbet kan grupperne arbejde, hvor de vil på skolen. Der er fælles møder, og derefter arbejder grupperne videre på egen hånd.

Eleverne skal med afsæt i deres visioner, drømme og erfaringer fra deres praktik arbejde med at udvikle den ideelle institution. De har arbejdet ud fra tankerne om, at forhold kan forbedres til gavn for fremtidens brugere af institutionerne. Et af målene med entreprenørskabsforløbet "Den ideelle institution" er, at eleverne skal give deres idéer til forbedringer videre til den institution, hvor de har været i praktik. Alle elever har i fem uger arbejdet med indholdet i entreprenørskabsprojektet.

Observation og interview er foretaget på elevernes sidste dage i forløbet, hvor de skal fremlægge i grupper som afslutning på det fire uger lange entreprenørskabsforløb "Den ideelle institution"

\section{Lærernes intentioner med undervisningseksperiment omhandlende entreprenørskab}

Læreren fra undervisningseksperimentet 'den ideelle institution' fortæller, at lærerne med deres undervisningseksperiment, ønsker at bringe eleverne ud af deres komfortzone, ved at få dem til at tænke videre, dybere, og anderledes. Derudover, fortæller læreren, har de også ønsket at fremme elevernes mod gennem arbejde med deres personlige indstilling. Dette har de bl.a. gjort ved faglige indspark om f.eks. den kognitive diamant. Desuden er det et bevidst didaktisk valg fra lærerens side, at undervisningseksperimentet omhandlende entreprenørskab, er tilrettelagt som et tværfagligt forløb. Hertil siger læreren:

"På stedet her arbejder vi som sagt meget tværfagligt. Vi arbejder $i$ værksteder. Et eller andet sted er det forvirrende for vores elever, fordi de fär at vide, at der findes en række fag på uddannelsen, men dem bryder vi faktisk op. Alt hvad der foregår på skolen er tværfaglige projekter, hvor eleverne til tider kan have lidt svært ved at se, hvornår har det har noget at gøre med dansk og pædagogik og sådan noget. $V i$ arbejder tværfagligt fordi vi gerne vil have, at undervisningen ligner virkeligheden, hvor man jo heller ikke går og tænker "nu anvender jeg dansk" eller lignende" (Lærerinterview).

Det, at læreren fremhæver virkeligheden som afsæt i det tværfaglige entreprenørskabsforløb, er efter lærerens vurdering et vigtigt forhold for at fremme deltagelse, fordi lærerne oplever, at det fremmer elevernes engagement $i$ arbejdet med opgaven gennem samspil med praksis og det arbejdsområde, som de er optaget af. Lærerne mener, at de tydeligt kan se gennem tegn på elevernes handling, at det fremmer motivation og læring. 


\section{Undervisningseksperiment 2: Social og Sundhed, Hovedforløb, PAU}

På EUD Social og Sundhed, Hovedforløb på PAU, har lærerne udviklet et entreprenørskabs undervisningseksperiment med fælles tema - "nærhedspraksis i undervisningen", som går på tværs af alle timer i fagene, bevægelse og idræt og pædagogik. Der er ca. 30 elever i alderen 18- 25 år. Forløbet "nærhedspraksis" ligger i forlængelse af elevernes praktikforløb, og varer i tre uger. Det er bygget op over de entreprenørielle dimensioner. Eleverne skal udvikle en aktivitetskasse med lege, som de skal afprøve i praksis. De skal besøge en institution for at pitche deres idéer om lege i aktivitetskufferten og høre, hvad personalet synes om det. Ugen efter skal de besøge samme sted for at lave aktiviteten med børnene. Eleverne skal modtage feedback fra de fagprofessionelle. De arbejder i skiftende grupper, som læreren bestemmer, men i forløb som dette kan de selv bestemme. Kravene er, at de selv skal finde en målgruppe, og at aktiviteten skal være noget nyt. Krav til deres produkt - en motorikkuffert er, at børnene i daginstitutionerne skal kunne se på genstandene i kufferten, når de åbner den, få forestillinger om hvad aktiviteten går ud på- måske er der endda noget, de kan vælge imellem.

\section{Lærernes intentioner med undervisningseksperiment omhandlende entreprenørskab}

Læreren har valgt at arbejde med entreprenørskab, fordi han ser et behov for mere praksisnærhed i undervisningen, og mener, at entreprenørskab som fænomen har praksisnærhed indbygget som en grundforståelse. Læreren fra undervisningseksperimentet "nærhedspraksis" udtrykker ønske om, at deres entreprenørskabsforløb skal tage afsæt i virkeligheden og, at dette bl.a. gøres ved, at eleverne arbejder mere helheds- og projektorienteret gennem tværfaglighed.

\section{Undervisningseksperiment 3: Social og Sundhed, GF2}

EUD Social og Sundhed, GF 2 - social og sundhed. Forløbet er et entreprenørskabsprojekt som kører på grundforløbet i faget "Innovation", som er en del af fagpakken på grundforløbet. Forløbet varer 5 uger, og der er to klasser slået sammen med ca. 40 elever eller mere, i alderen er mellem 16- 40 år. Der er to undervisere på innovationsprojektet, som begge har erfaringer fra tidligere innovationsforløb.

Entreprenørskabsprojektet er bygget op over innovationstrappens trin og processer. Eleverne skal arbejde med ét tema fra udfordring over idé til forslag på løsning. De skal ud på besøg i praksis undervejs i forløbet. Eleverne arbejder i grupper efter valgt tema, og skal løbende modtage feedback fra underviserne. Som afslutning på et langt forløb skal eleverne pitche og præsentere gruppevis $i$ et storrum arrangeret som en udstilling. De får bedømmelse i form af afsluttende feedback og karakterer.

Lærernes intentioner med undervisningseksperiment omhandlende entreprenørskab Med afsæt i entreprenørskabshjulet og innovationstrappen er det lærernes intention, at lære eleverne at arbejde med entreprenørielle processer, og derigennem udvikle forståelse og erfaring for tankegangen. Som læreren udtrykker "Det er denne her tankegang som de skal i gang med, og den er nemmere for nogle, end den er for andre". Eleverne skal arbejde med udviklingen af en eller anden form for værdiskabelse i deres fag, og de starter forløbet med spørgsmålet "hvad vil det sige at skabe værdi inden for et fag? " For ikke at låse eleverne fast $i$ hvad et fag er, ønsker lærerne, at eleverne får indsigt i nogle tværgående temaer, hvor der er mulighed for værdiskabelse inden for EUD - social og sundhed. Temaerne som de kan vælge ud fra interesse er teamarbejde, ledelse og organisation, borgeren og sidst fremtidens medarbejder (sig selv). Lærernes intention er, at eleverne ser mulighederne inden for området herunder åbne for mulighed, for at de kan se sig selv blive selvstændig eller iværksætter og / eller se muligheder i faget med f.eks. inddragelse af velfærdsteknik.

\section{Undervisningseksperiment 4: Social og Sundhed, GF 1}

På EUD Social og Sundhed, GF 1 har lærerne tilrettelagt undervisningseksperimentet "Innovationsprojekt om frivilligt arbejde". Faget innovation er en del af fagpakken på GF1, og det varer 3 
uger. Der er ca. 25 elever i klassen i alderen 15-16 år. Der er to undervisere knyttet til forløbet, hvoraf den ene er uerfaren i forhold til at undervise gennem entreprenørskab, den anden mere erfaren. Entreprenørskabsprojektet er bygget op omkring en innovationsproces. Eleverne skal arbejde med et selvvalgt tema inden for frivilligt arbejde - fra udfordring over idé, til forslag til en løsning. De skal i forløbet ud på besøg i praksis. Eleverne skal arbejde med innovationsprocesser, strukturer støttet af værktøjer og modeller. Lærerens rolle er at sætte rammer, strukturer, og give feedback. Observationerne der ligger til grund, er fra en arbejdsdag i slutningen af projektet. Eleverne er ved at lægge an til landing, få overblik over deres proces og forløb. Lokalet er præget af deres arbejde. Der er fyldt med billeder, post-its, plancher med mere.

\section{Lærernes intentioner med undervisningseksperiment omhandlende entreprenørskab}

Lærernes intentioner med deres entreprenørskabsprojektet er at tilrettelægge et forløb hvor den entreprenante proces er meget tydelig for eleverne. De (lærerne) er optaget af at udvikle elevernes entreprenante mindset forstået som, at de er meget opmærksomme på, at eleverne skal opleve foretagsomhed, at de kan blive særlig motiveret til at handle fordi, det kan gøre en forskel nogen. Lærerne ønsker, at eleverne bliver bevidste om den værdi, der er i at gøre en forskel for andre. Lærerne ønsker også, at de med deres forløb kan engagere eleverne omkring en interesse, som eleverne kan se og arbejde med i sammenhæng til frivilligt arbejde, som er kernen i projektet. Det vil sige, at lærerne er optaget af, at eleverne får en oplevelse af, at kende til betydningen af social entreprenørskab gennem frivilligt arbejde. I projektforløbet er lærerne meget bevidste om, hvordan de kan inddrage de fire dimensioner gennem forskellige didaktiske greb, som de eksperimenterer med under deres projektforløb. Eleverne skal arbejde med netværk for at inddrage deres omverden, og få deres netværk i brug i sammenhæng til deres frivillighedsprojekt. Som læreren udtrykker det: "vi, har snakket meget om det her med handlingskompetencer og det der med man skal ud og se hullerne i samfundet, og gøre en forskel. Alle elever har omverdens relationer og netværk, som kan komme i spil".

\section{Didaktiske billeder på elevernes deltagelsesmåder}

Dette afsnit vil, belyse i billeder, hvilke didaktiske greb, som ser ud til at åbne for elevernes deltagelse i undervisning gennem entreprenørskab i EUD Social og Sundhed, og dermed vurderes at have betydning for elevernes motivation og læring. Hvert billede indledes med en didaktisk markør for entreprenørskabsundervisning, hvilket betyder, at markøren knytter sig til didaktiske greb af betydning for, at eleverne udvikler entreprenørielle kompetencer. Disse billeder er fra observationer og interviews med fokus på, hvilke muligheder eleverne har, for at deltage i eksperimentets undervisning.

Billede 1, Didaktisk markør for deltagelsesmåder i entreprenørskabsundervisning: At bruge teoretisk, autentisk og erfaringsmæessig indsigt som afsæt for at åbne sig for nyt

At bruge faglig indsigt som afsæt for at eleverne åbner for nye muligheder og andre veje til svar på de udfordringer som eleverne arbejder med i deres projekter, er et af flere forskellige didaktiske greb, der indgår i eksemplerne fra social og sundhedsuddannelser, og som ser ud til at være en faktor, for at styrke elevernes aktive deltagelse i forbindelse med udviklingen af deres proces eller produkt i det entreprenørielle forløb.

Nedenstående situationer er fra undervisningseksperimentet, hvor eleverne arbejder med at udvikle en aktivitetskuffert, og derved skal udvikle eller tænke nyt omkring børns leg. Læreren giver et fagligt oplæg og eleverne lytter. Han giver eleverne teoretiske begreber med det formål, at eleverne kan kvalificere deres idéer. Lærerens intention er altså, at eleverne skal have en faglighed at stå på, en faglig ballast som afsæt for at udvikle nyt. Det 
er lærerens intention, at denne faglige ballast er med til at give professionalitet til de kommende pædagogiske assistenter - når de skal se sammenhænge mellem aktiviteter omkring børnenes leg og børns udvikling og læring.

Undervisningen starter som klasseundervisning, hvor læreren fortæller mens han skriver stikord på tavlen om, hvad entreprenørskab betyder i forhold til arbejdet som pædagogisk assistent. At det for eksempel handler om at udvikle nye former for leg. Læreren henviser til, at han før har fortalt om Bourdieus teorier om kapitalformer. Han fortæller både om kulturel- og socialkapital i sammenhæng til leg. Han siger, at social kapital, for eksempel, kan handle om at have en ven, blive uvenner og som voksen at få et netværk. Kulturel kapital, fortæller han, handler om f.eks. uddannelse, og at tale på en bestemt måde. Han slutter det faglige oplæg af med, at fortælle eleverne, at pædagogik derfor handler om dobbelt socialisering. Læreren fortæller, at det gælder både elevernes personlige udvikling og socialisering, samt at det er den professionelles (her pædagogens opgave) at understotte barnets udvikling af både social - og kulturel kompetence (fra observationsnoter).

Eleverne sidder roligt og lytter. Lærerens forklaringer af de teoretiske begreber er omsat til begreber, eleverne forstår. Læreren spørger til elevernes idéer til nye lege, der understøtter den teoretiske viden. Nogle få byder ind med eksempler, der kobler til begreberne. Læreren fortæller, at det entreprenante ved uddannelsen handler både om evner man har brug for som pædagog (eleverne får en ny habitus, hvor de får kulturel kapital gennem uddannelsen og sociale kompetence som for eksempel at være anerkendende). Og til at kunne omsætte denne kompetence og derigennem understøtte og udvikle disse evner hos børn (fra observationsnoter).

Om ovenstående siger eleverne:

Vi laver ikke bare aktiviteter for at lave aktiviteter. Vi gør det jo ikke bare for, jo det kan man godt gøre, det for at have det sjovt, men der går for det meste læring i det [underforstået, at teorien er med til at kvalificere elevernes idéer til aktiviteter]. (fra elevinterview)

En elev siger: "Det giver os også et billede af at der er et formål. At vi ved hvad vi vil have ud af det. At det ikke bare bliver sådan noget "vi vil lave det her fordi det er sjovt".

En anden siger videre: Også så vi ikke spilder deres tid. At vi kommer derud bare for at børnene skal have det sjovt. Men, at forældrene også får af vide, at der er nogen fra en skole, der er kommet ud og har lavet denne her aktivitet, hvor børnene får styrket deres sociale kompetencer, deres krop og bevægelse" (fra elevinterview)

I Ovenstående eksempler ser vi, hvordan eleverne først i selve situationen sidder fordybet og forholder sig til indholdet i det teoretiske oplæg i relation til det konkrete entreprenante produkt (aktivitetskasse), som de er ved at udvikle. Eleverne skal ikke "bare" forholde sig noget teoretiske indhold, men det forventes, at det kan anvendes i konkrete autentiske situationer forbundet med deres fremtidige arbejdsliv - altså professionalitet. Det teoretiske oplæg er altså koblet til to forhold inden for socialisering - både barnets og den kommende pædagogiske-assistent, og de to forhold kan være med til at støtte muligheder for elevers succesoplevelser.

En anden situation, hvor eleverne ser ud til at anvende deres teoretiske og erfaringsmæssige indsigter, er når de skal observere praksis og oversætte til konkret praksis. En elever siger:

" Der gik en 3-4 uger for mig, fordi jeg også selv skulle lære børnene at kende forst, så jeg vidste hvad for nogle kompetencer de [børnene] havde. Og på den måde få viden fra dem 
[praktikstedet] vi skal ud og snakke med, hvilke kompetencer deres børn har og så videre, så ved jeg også hvordan min aktivitet skal tilrettelægges " (Elevinterview)

En anden udtrykke det således:

"Ligesom refleksioner og observationer er også det der gør, at vi kan lave de her aktivite-

ter. Som sagt så går man ikke bare ud og laver dem. Jo du kan godt gå ud og lave en aktivitet, men så ved du ikke, om du får den succesoplevelse, som du selv gerne vil have. Så det her med, at vi går og observere "han er ikke så god til at samle små sten op fra jorden, det er noget med hans finmotorik" så kan man jo putte det videre og lave en aktivitet ud af det". (Elevinterview)

I eksemplet ser vi, hvordan inddragelse af både teoretiske viden om motorik, udforskende handling gennem observation i praksis og efterfølgende refleksion over fund omhandlende (idet her tilfælde) et barns motoriske kapacitet, er med til at åbne for nye perspektiver, som eleven kan inddrage i sin aktivitet.

Som eleven siger, så hænger faglig nysgerrighed, koblet til faglig udvikling, sammen. En elev fortæller en succesoplevelse, der omhandler transfer mellem teori, faglig observation og praksis, som skaber entreprenøriel handlen på baggrund af faglig teoretisk indsigt og observation:

"En gang om dagen der lavede vi bare noget, hvor det kun var mig og ham [et barn i en institution]. Så jeg sørgede for at han blev bedre for hver dag i løbet at det halve år [hvor eleven er i praktik]. Da vi startede der kunne han [et fra en institution] ikke engang kravle op på en skammel. Da vi var færdige, der kunne han kravle op i tårnet og køre ned af rutsjebanen. Han kunne spille bold med de andre og han var ikke bange mere på den der måde, fordi han også havde fået nogle succesoplevelser. Hvis jeg ikke havde vidst, at det var det jeg skulle prøve at styrke hos ham, så havde jeg ikke vidst hvad fokus skulle være. Teorien gør aktiviteten mere stærk. Man kan se hvad de [børnene] får ud af den". (Elevinterview)

En tredje situation, der belyser hvordan teoretisk og erfaringsmæssige indsigter åbner for elevernes deltagelse i undervisningen og dermed er med til at fremme elevernes motivation og læring, er en situation, hvor lærerens intentioner er, at et teoretisk indspark skal være med til at give eleverne mere selvtillid og stof til egen refleksion, ved at de får indsigt $\mathrm{i}$ en sammenhæng omkring, hvad man tænker om sig selv, og hvordan man ser sin egen faglige præstation.

"for eksempel en af de seneste ting, der har været er, at vi er blevet hevet op i midten hvor vi alle sammen har siddet tæt oppe ved tavlen og så har vores lærer fortalt om at ændre sin adfærd i forhold til sin tænkning, med den kognitive diamant. Det her med, at jeg kan godt, eller jeg kan ikke, og hvordan man tænker om sig selv. Vores lærer fortæller hvordan det påvirker ens arbejde om du starter med en holdning, der er, jeg kan godt eller en holdning, der hedder, jeg kan ikke. Det synes jeg var en super god måde, at blive hevet ud af sin vanetænkning på, at få den der reminder om, at nu skal man huske det”. (elevinterview).

Eksemplet viser, hvordan eleven oplever, at en teoretisk forstyrrelse kan åbne for, at hun får mulighed for at arbejde med sin personlige indstilling i forhold til hendes selvværd, og betydningen af at tror på sig selv, og at det man gør er godt nok. 
En sidste situation som giver mening at fremhæve, er brug af autentiske cases eller gæstelærere udefra.

Undervisningssituationen, hvor eleverne får ny faglig indsigt som afsæt for deres entreprenørskabsforløb, er fra et GF 1 forløb, hvor lærerens intention er, at give eleverne en fælles forståelse af hvad frivilligt arbejde er, og hvad det betyder. Læreren inviterer en gæsteunderviser, som kommer fra en frivillighedsorganisation. Eleverne lytter, får indsigt og information. De laver efterfølgende en quiz. Gæstelærere udefra, tyder på at åbne for elevers nysgerrighed og indsigt på en anden måde, end hvis eleverne selv skulle opsøge viden. Om undervisningsmåden siger en elev:

"Det at få besøg udefra, er i stedet for, at man skal sidde med computeren og søge efter informationen. Det at arbejde på computeren kan betyde, at man måske kommer til at lave det lidt forkert, fordi man måske troede at frivillig er noget andet end det egentligt er. En anden elev siger" Så vi fik også en mere klar definition om hvad frivillig egentlig er. Det er også meget praktisk, at vi alle sammen forstår det på nogenlunde sammen måde, dvs. at der ikke er nogen, der går ud og laver noget med en person som måske var lønnet, i stedet for frivillig. Nu er vi alle sammen enige om hvad frivillige er" (Elevinterview)

Eksemplerne viser, hvordan læreren giver eleverne forudsætninger for, gennem forskellige former for faglige indsigter, at kvalificere deres idéer til de entreprenørskabsaktiviteter som de skal til at udvikle. De får mulighed for at kvalificere deres idéer til at udvikle forskellige produkter eller processer, som de skal ud og afprøve. De faglige indspark ser ud til at være med til at støtte muligheder for elevers succesoplevelser, fordi den faglige ballast og dybere forståelse får betydning for kvaliteten af det som de udvikler. Der er eksempler på, at eleverne udvider deres forståelse af professionalitet, samtidig med at det åbner for mere mod og selvværd gennem det skub, eleverne får til refleksion over personlige ressourcer og egne interesser. Som en lærer udtrykker det:

"Vi taler så tit om det her med at, vi har elever der kan lire af hvad empati er (teoretisk viden) og så er der nogen hvor det falder dem fuldstændig umiddelbart at være empatisk, eller som er blevet $i$ stand til at handle empatisk (praktiseret og erfaret viden) " (lærerinterview)

Billede 2, Didaktisk markør for deltagelsesmåder i entreprenørskabsundervisning: At fremlægge eller præsentere sit projekt i samarbejde med andre

Et andet didaktisk greb som åbner for elevernes deltagelsesmåder, der understøtter udviklingen af elevernes entreprenante mindset, er gruppefremlæggelser.

Nedenstående situation er fra en observation, hvor eleverne fremlægger i forbindelse med afslutningen på et entreprenørskabsforløb. De skal fremlægge for hinanden. De deltagelsesmåder som observeres, er relationerne og samarbejde under fremlæggelse i grupper, og feedback fra medstuderende og undervisere.

Fremlæggelserne foregår i et stort fælles lokale. Det er et værkstedslokale, hvor der hænger plakater og der er reoler, der adskiller rummet. Deltagerne sidder omkring scenen, der 
er gjort klar til at grupperne kan fremlægge. Der er mørkt i lokalet, kun lyst op af PowerPoint. De drikker kaffe og andet, der er slik og godter. Det virker som om, at fremlæggelse er gjort hyggelig. Christian siger også, at det ikke er en eksamen. Christian lægger op til, at grupperne selv kan vælge om de vil forstyrres under fremlæggelse. Der er sat en halv time af til hver gruppe.

Ovenstående fortæller os noget om læringsmiljøet under fremlæggelse og det viser, at der er en fysisk indretning, der tager form efter hvilke deltagelsesmåder, der er i spil i entreprenørskabsundervisningen. Under fremlæggelse, er det vigtigt, at rummet eller værkstedet, der tidligere bar præg efter aktivitet i forbindelse med gruppernes arbejde, nu er ændret til at være et rum med en stemning, der er karakteriseret ved at være dæmpet, tryg, fælles og hyggelig. Det er et rum, der taler i retning af tillid og imødekommenhed. Efter en pause griber læreren en mulighed for at fortælle eleverne, hvor vigtigt det er, at der ikke grines under fremlæggelsen og betydningen af, at alle føler sig trygge. Han siger også, at det er en træning til deres fremtidige arbejdsliv. Den sidste fremlæggelse sætter i gang. Læreren appellerer til, at alle er gode ved hinanden og, at de fastholder koncentrationen under sidste fremlæggelse.

Efter fremlæggelserne starter en debat, der handler om, hvordan de som elever oplever, at omverdenen ser på pædagogiske assistenter.

En pige fortæller, at der hvor hun var i praktik blev der lyttet, og hun fik mulighed for at gennemfore forbedringer. Hun prøver at motivere de andre med et forslag om, at tænke videre når ideen er blevet er skudt ned. (fra observationsnoter).

Situationen fra fremlæggelserne viser, at det er meget vigtigt, at eleverne føler sig trygge og at de føler, at læreren og klassekammerater er med til at skabe trygheden. Vi ser i eksemplet, at læreren har gjort en del ud af at skabe den rette stemning og skabe opmærksom omkring dette. Han giver også elever ros og støtter dem med opmuntringer undervejs. En elev udtrykker i nedenstående citat, hvordan gruppen støtter en gruppedeltager, der er usikker og nervøs for at fremlægge:

"En pige i vores gruppe hun er meget stille og meget usikker. Hun er ikke så glad for at fremlægge, men der havde vi også stor fokus på. Alle skal få sagt noget, det skal ikke kun være mig, der står, alle skal have lov at sige noget, men det skal være noget, der er rart overskueligt. Vi fik en rigtig god fordeling og hun [hende der er usikker] fik lov at vælge først hvad hun gerne ville. Fordi så var det rart for alle, uden at jeg stod og plaprede løs og sagde det hele".

Situationen viser, at gruppen tager hånd om, at fremlæggelse er en kollektiv opgave, og dette kan hænge sammen med den kollaborative arbejdsform, hvor de har været fælles om opgaven og der skabes en teamspirit. Der sker en fælles læring og de kan støtte hinanden og dermed fastholde et fælles engagement, hvor ingen melder sig ud, men i stedet får en succeshistorie.

En anden pige fra fremlæggelsen, der selv er usikker, siger om sin oplevelse med fremlæggelser under entreprenørskabsforløbet:

Elev 1:"Jeg har jo fremlagt mange gange. Både i folkeskolen og i 10. klasse, men jeg synes, at de er bedre til det her, især læreren [eleven siger navnet], synes jeg er god til at gøre og sige, at det ikke kun er det [fremlæggelsen] der tæller. Fordi det synes jeg, det var meget i folkeskolen, at "nu skal I præstere og vi bedømmer jeg på det her". Hvor det er lidt mere "vi tænker også på alle de andre uger I har siddet og knoklet, og det er ikke kun denne her fremlæggelse". 
Elev 2: "Man gør det ikke for, at man skal stå og være nervøs, men man gør det for at fremvise det man har lavet. Det er ikke en fremlæggelse, men man fremviser det. (elevinterview)

Her ser vi, at det betyder meget, at den rette stemning er tilstede i rummet for at sikre elevernes motivation til deltagelse i fremlæggelse. Eleven giver udtryk for, at hun ikke oplever, at hun bliver bedømt på sin fremlæggelse, som hun har prøvet tidligere. De didaktiske greb som læreren har gjort brug af i sammenhæng til fremlæggelse tyder på, at de støtter bl.a. kreativitetsdimensionen ved at lade fremlæggelsen være en aktivitet uden bedømmelse og fokusere på produktet som så kommer i centrum - ikke eleven selv.

En anden elev fortæller, at hun er blevet meget mere tryg ved at fremlægge, fordi hun nu har prøvet det mange gange, og fordi hun går i en fast klasse, hvor de kender hinanden og kender betydningen af anerkendelse:

"Jo flere gange jeg får fremlagt, jo mere tryg bliver jeg. Og det er bare at komme igennem det så godt som muligt. Og det er blevet nemmere synes jeg, især også på denne her skole, fordi man har været længere tid sammen" (elev interview).

En situation fra innovationsprojekt på GF 2. Der er et stort værksted - to værksteder er slået sammen. Der er mange grupper ca. 10, som skal holde messe eller udstilling senere på dagen. Der kommer gæster udefra og andre ledere og lærere fra skolen. Der er en meget spændt og arbejdsom stemning i lokalet. Der roder på den gode måde og det vidner om, at eleverne meget gerne vil præsentere deres projekter og produkter på den bedste vis. Lærernes roller er den dag at stotte, skabe overblik og tryghed. Det synes som om, at der er meget på spil for eleverne. Det er summativ evaluering og karakter som afslutning. Det synes at gøre eleverne nervøse, men også, at gøre dagen betydningsfuld.

Der er en gruppe længst nede i lokalet. Fem kvinder, de er oppe $i$ årene. De står sammen og gør deres plancher og andet klar til deres præsentation senere på dagen. De andre elever fra andre grupper ser på gruppens plancher og synes de ligner en halv milliard. Der er en meget god stemning i gruppen. De er helt tydeligt "oppe at køre" og fulde af forventninger. De virker stolte af deres projekt. De har haft borgeren som målgruppe for fremtidens ældrebolig (plejehjem) (fra observationsnoter)

I denne før situation inden fremlæggelse, er der en stemning af koncentration og stor arbejdsomhed. Eleverne ønsker helt sikkert, at fremlæggelsen skal gå godt og det ser ud som om, at de er meget stolte over deres produkter som alle tager afsæt fra faglige kontekster. Præsentationsformen er anderledes end eleverne er vant til. Lærerne har flyttet hele arrangementet ud i et af skolens fælles lokaler, hvor andre elever, lærere og andre udefra kan se og høre om elevernes produkter, som de har udviklet i deres innovationsuge. Disse forhold op til fremlæggelse ser ud til at motivere eleverne, og deres deltagelse er præget af ansvar og engagement.

I de forskellige situationer omkring fremlæggelser eller fremvisninger, er der mange eksempler på, at det giver eleverne en mestringsoplevelse. Den involvering og elevinddragelse gennem samskabelse gør, at flere elever giver udtryk for at de får succesoplevelser, der støtter deres selvværd og faglige udvikling. 
En lærer fortæller om sine iagttagelser:

"Jeg synes faktisk, at de her fremlæggelser som vi har set, har udskilt sig fra de tidligere gange jeg har set det. Jeg kunne sagtens sætte mig og pikke til fejl og mangler, men hvis jeg kigger på det med positive briller, så har det en helt anden kvalitet og en helt anden opmærksomhed på netop børn (brugerne), som eleverne har udviklet institutionerne til. Det her det handler om det der kan gøres bedre (for brugerne) og mindre fokus på mig (eleven) på min (elevens) praktikplads. Jeg synes fagligheden er stærkere, end jeg har set tidligere. I den gruppe der viste os det i dag, der var et par elever som stod der på en måde jeg aldrig har set før. Med en sikkerhed og en faglig begrundelse for deres valg, som jeg faktisk ikke troede de kunne. Hvor den kommer fra ved jeg ikke, men jeg kan håbe, at det handler om denne her reaktion på for eksempel at de har taget afsæt $i$ et autentisk behov eller det at kvalificere noget" (lærerinterview)

Samlet set, så fremstiller billedet didaktiske situationer med stort elevengagement og aktiv deltagelse, hvor eleverne i fællesskab har taget et ansvar for at præsentere deres arbejde. Den måde som de forskellige lærere har tilrettelagt aktiviteter i sammenhæng til fremlæggelser og / eller fremvisninger tyder på, at de har været optaget af, at elevernes produkter som de skal fremlægge, skal vise muligheder der åbner for nyt. Lærerne og elever er også meget bevidste om, at bearbejde usikkerhed gennem anerkendelse, tryghed og ros i forbindelse med fremlæggelser af faglig autentiske produkter eller processer og billedet viser entydigt, at fremlæggelser er med til at give elever en kollektiv oplevelse af mestring .

\section{Billede 3, Didaktisk markør for deltagelsesmåder i entreprenørskabsundervisning: At udvikle ideer til processer eller produkter}

I forbindelse med entreprenørielle forløb, er det en helt centralt didaktisk aktivitet, at åbne for elevernes mulighedstænkning, ved at de får idéer og ser mange muligheder for veje som svar på det behov eller den udfordring som de er optaget af.

Nedenstående er en række citater fra forskellige elever (fra GF1 til Hovedforløb), der har deltaget i entreprenørskabsforløb og hvor de udtaler sig om processen, at udvikle idéer:

"Brainstorm er god fordi man kommer frem med alt, og de andre lytter med".

"Det er godt med metoden at stille spørgsmål til idéer. Det kan hjælpe til at kvalificere de forskellige idéer".

"der er meget frihed til at skabe sin egen ide. Men det er også godt nok, at der er nogle rammer på en eller anden måde, så man ikke kommer for bredt ud.

"Idéer gør det lettere at være positiv uanset hvor svær opgaven er. Man er normalt god til at opgive, men har lært, at det er vigtigt at blive ved".

"Jeg kan godt lide det med at tænke i nye tanker eller komme med noget nyt i stedet for bare skulle lave det sammen om og om igen. Få lov til at komme med noget andre folk ikke har fundet på. Komme med din ting, noget du kan". 
"Det er ikke så nemt at opfinde noget som man tror kan noget. Vi har været positive ved, at vi har taget det som det kommer".

"En ting er at få en idé. Det er jo så den ene del af det, men jeg tænker også, at der også en del af det, der handler om, at når man så får en ide, også bliver $i$ stand til at gennemføre den. Fordi, hvad nytte er det med ideer, hvis de ikke kan blive til noget?"

"Lært at entreprenørskab er vigtigt for vores samfund. Hvis man har en ide, så kom ud med den. Bedre at få idéen afsted".

"Når vi kommer ud på arbejdsmarkedet, hvis man ser en fejl, så kan man komme med en ide til løsning. Det giver en følelse af, at man kan gøre noget bedre, når også de erfaren laver en fejl"

Citaterne vidner om, at eleverne engagerer sig i at få idéer, og det stiller krav til dem om aktiv deltagelse og refleksiv forholden sig til sammenhængen mellem idé og den faglige udvikling, som idéen skal kvalificere. Citaterne giver et indblik i det bevidsthedsarbejde og dermed også læring med idéudvikling og kvalificering af idéer, som eleverne oplever.

"I starten fik vi nogle forskellige opgaver, da vi sad ved vores borde, hvor vi så skulle sidde og snakke om overvægt, psykisk sårbare og alle mulige ting. Så kunne vi så vælge de her overemner, og så tænkte vi, okay hvad er mest spændende, hvad ville vi bedst kunne klare, hvad vi føler os tryggest ved og hvad kunne vi finde ud af. Så valgte vi psykiske sårbare, og så begyndte vi lidt med idéer- hvad vil vi gerne have under det her emne. (elev GF 1)".

Ovenstående citat viser, at det har betydning, at eleverne kan vælge et, for dem fagligt relevant emne og det motiverer dem, at det er interesseorienteret, men også at emnet giver dem en tro på, at de kan mestre det og udrette noget særligt. Her viser det, at tilpas udfordrende opgaver, hvor der kan vælges, er med til at åbne for aktive engagerende deltagelse med fællesskab om temaet.

Et andet citat fra en lærer belyser betydningen af ejerskab og interesse for det som eleverne vælger at udvikle, set i sammenhæng til deres engagement. Han kommer ind på, at mange af eleverne ikke plejer at være så engagerede. Han siger: "De har virkelig følt, at det er deres eget det her. Vi (lærerene) plejede bare at komme med noget materiale eller nogle ting og så skulle de lave det. Men lige pludselig så er de ligesom kommet over denne her mur med at sætte denne her tankegang i gang. Vi ser nu at de føler, at det er deres eget. Vi har også bidt mærke i betydningen af, at de selv kan vælge. De kan beskæftige sig med noget, der interesserer dem, det har betydet meget for nogle af dem" (fra lærerinterview)

At bryde vanetænkningen med kreative aktiviteter omkring aktuelle temaer, der stimulerer til nyt, ser ud til at være et didaktiske greb som lærerne må byde ind med, for det sker ikke nødvendigvis af sig selv. En elev fortæller om processen:

"Så vi prøvede det der med at tænke ud af boksen fordi vi ender tit med, eller det synes jeg selv, at tage de der gamle danske kulturelle lege, som gå i dåsen og alle mine kyllinger kom hjem. Det har været en stor udfordring og skulle prøve noget nyt også, synes jeg $i$ hvert fald, hvis man skal finde på noget helt, nyt". 
Citatet viser, at det kan være svært at tænke nyt og idéudvikling som fagdisciplin. Og at ændre på elevrolle fra formidler af kendt viden til aktiv skaber og medudvikler af ny viden. En sådan rolle, er ikke lige nem for alle, at tage på sig og derfor er det vigtigt, at der bliver arbejdet bevidst med denne usikkerhed.

En anden elev udtrykker det således:

"Jeg kommer nok mest med idéer, når jeg virkelig skal og bliver lidt tvunget til det. Men så har jeg det også okay med det, og så får jeg også positiv feedback på det jeg så kommer med, så jeg ved jo godt at jeg kan. Og det ved læren også, det er bare lige det der med at komme ud over stepperne". (elevinterview)

Nedenstående citater illustrerer betydningen af didaktiske greb, der inddrager autentiske problemstillinger fra omverdenen. I citatet, hvor en elev fortæller, at det er meget nemmere, at få idéer efter praktik, fordi idéerne bliver hægtet op på virkelige hændelser og behov, viser dette.

"Jeg vil sige det har altid være nemmere at finde nogle nye aktiviteter, når man lige har været ude i praktikken. Og fordi, man ved mere hvad de forskellige kan og hvad, der bliver taget godt imod".

En anden elev udtrykker det således:

"Jeg synes jeg havde en rigtig god praktik, hvor jeg fik en masse gode ideer og jeg blev inspireret af mange tinge. Jeg synes de (praktikstedet) gjorde det rigtig godt". (HF, Elevinterview)

Når der er tale om kollaborativt arbejde i det entreprenørielle forløb som eleven deltager i, forstået som, at eleverne arbejder sammen om at udvikle idéer for derefter at fremstille, evaluere, kvalificere, og fremlægge deres produkt eller proces, er det nødvendigt, at de kan udvælge den idé sammen, som de kan komme længst med, som svar på den udfordring eller det behov som de er optaget af. I nedenstående eksempel får vi indsigt i den vanskelighed, det kan være for elever at udvælge en idé til at kvalificere eller nytænke forhold fra praksis, og hvordan et didaktisk greb fra læreren kan skabe læring og motivation i en ellers for eleverne svær proces. En elev fortæller:

"Det var nok det her problem med, at vi kom med mange forskellige ideer, og så var det ofte ideer som man selv havde oplevet, som én person havde oplevet et sted, men de andre vidste ikke noget om det, de havde slet ikke oplevet noget som helt lignende, så det var lidt en forhindring i forhold til at bygge videre på ideer. Men jeg synes den der cirkelskrivning (metode) den gav i hvert fald rigtig god mening for mig. Det med at skrive videre på de ideer de andre havde, selvom jeg ikke selv havde oplevet tingene" (elevinterview)

En lærer siger om en lignende proces:

Det som vi har bedt dem (eleverne) om, er i højere grad end tidligere, at finde nye løsninger. Vi udfordrer dem på ikke at tage (kendte) løsninger ude fra praktikken alene og så anvende dem, eller noget de selv har provet en gang. Ligesom når vi nu arbejder med alle mulige pædagogiske aktiviteter, så skal det ikke være noget de (eleverne) kender i forvejen, men noget de videreudvikler eller opfinder på ny. Vores opgaver er at udfordre dem hele tiden på, at der skal være denne her innovationsdel ind over deres aktiviteter. Eleverne spørger hele tiden "skal det være nyt i verden?" Nej men det skal være nyt i den 
sammenhæng det opstår $i$, og vi ved jo, at det kan være svært at skulle opfinde på tid, som det nogle gange er. Så kravet om, at det er splinter nyt og aldrig set før, det synes vi er for stort og det kan også være skræmmende for mange. (lærerinterview)

Ovenstående eksempel viser, at lærerrollen er central under idéudvikling. Læreren fortæller, at benspænd og små skub er med til at åbne op for elevernes deltagelse i sammenhæng til idéudvikling og disse didaktiske greb bliver betydningsfulde for, for eksempel at stimulere elevernes nysgerrighed og undren og dermed også perspektivere deres faglighed i sammenhæng til betydningen af, at få eleverne til at se sig selv som medskaber af praksis.

De forskellige situationer og mange citater fra ovennævnte billede om at udvikle idéer til udvikling eller forbedringer af aktiviteter, produkter og processer, er en pædagogisk og didaktisk disciplin, der har stor betydning for at eleverne oplever succes i et entreprenørskabsforløb. Godt begyndt på en idé, der tænder en gruppe elever og som kan skabe værdi for andre, er halvt fuldendt i en entreprenøriel proces. Med billedet fremstiller vi de forhold som kommer i spil i forbindelse med aktiviteten idéudvikling, og det er alt fra relationer mellem elever og elever og lærere, facilitering gennem benspænd og skub, autentiske problemstillinger, inddragelse af omverdenen med mere. Det betyder også, at brainstorm og post it gør ikke idéer, der alene kan skabe værdi. Idéudvikling er en kompleks didaktisk aktivitet med mange komponenter, der skal gå op i en højere enhed, for at idéen bliver det nødvendige afsæt for den entreprenørielle proces.

\section{Billede 4, Didaktisk markør for deltagelsesmåder i entreprenørskabsundervisning: At samarbejde i grupper}

Alle de undervisningseksperimenter som er repræsenteret under uddannelsesområdet EUD Social og sundhed er tværfaglige projekter med interessetemaer som eleven kan vælge sig ind på. Eleverne har været organiseret i grupper og de har samarbejdet om fælles opgaver i alle entreprenørskabsforløb.

Betydningen af roller under samarbejde i gruppe:

En gruppe fra innovationsprojekt på GF 2, hvor eleverne er kvinder over 40, samarbejder de om deres projekt- Fremtidens plejehjem. De er ikke vant med gruppearbejde og entreprenante processer, hvilket de begrunder i deres tidligere skoleerfaringer, hvor elevrollen har været, at gøre hvad læreren siger. De virker koncentrerede om deres opgave, meget orienteret om den fælles opgave og det udtryk som de forventer, at deres produkt skal udtrykke. En kvinde, som de andre tillægger stor værdi for gruppens trivsel og evne til at samarbejde, siger selv, at hun er gruppens klovn [hun skaber trivsel og godt humør]. De griner meget. De siger, at de har fået positive læringsoplevelser under projektforløbet. De tillægger det gruppen og samarbejdet. (observationsnotat)

Ovenstående situation fra et gruppearbejde vidner om, at eleverne har samarbejdet som et kollektiv, i forståelsen af, at de alle har en rolle og oplever, at de hver især har betydning for, at komme i mål med projektet. En af kvinderne udmærker sig ved at have en rolle som alle tillægger betydning. Hun kalder sig selv klovn, men hun er nok snarere indpisker og motivator samtidig med, at hun kan skabe en hyggelig, afslappet arbejdsom stemning. Det 
ser ud som om, at usikkerheden bliver vendt til styrke gennem den positive stemning og, at det giver gruppen mod til at overkomme det nye.

Et andet eksempel, der belyser roller i gruppen og betydningen af, at kunne slippe eller tæmme sin naturlige rolle:

For mig handler det altid rigtig meget om, uanset hvilket gruppearbejde jeg træder ind, hvilken rolle indtager jeg i gruppen. Jeg er meget fremtræden, jeg vil rigtig gerne tage denne her lederrolle. Det er en virkelig stor udfordring for mig at læne mig tilbage og andre tage lidt ansvar, fordi jeg vil rigtig gerne være med inde over det hele. [under forløbet] synes jeg, at jeg fik rigtig god mulighed for at øve, det her med at tage en lidt mere passiv rolle i gruppen i den institution jeg var ude $i$, fordi det netop ikke var mig, der havde alt ansvaret. Jeg har gjort et forsøg på at øve mig, $i$ alt den tid jeg har været på SOSU-skolen, men jeg har altid haft meget svært ved det der med at læne mig tilbage og sige "nu er det nogle andre". Jeg tror, at jeg skal blive bedre til at have fokus på, hvordan jeg kan gøre gruppearbejdet godt for alle, inklusiv mig selv". (elevinterview)

At forbinde sig i en gruppe:

"Gruppen er i konkret forstand, en meget lukket gruppe. De har 'muret' sig inde, bag skærme og man skal lede efter gruppen. De er fire/fem deltagere. De siger, at de har et godt samarbejde. Kemien, er god. De har selv valgt gruppe. Deres styrke er, at de har hver deres kompetencer, nogle har kompetencer fra praksis. Det er særlig de kompetencer (erfaring fra praksis) der fremhæves. To af deltagerne i gruppen har erfaring fra praksis. De andre to er startet på uddannelsen lige fra folkeskolen. De siger, at de er gode til at forklare for hinanden. "Nogen har forstået det på én måde, de andre spørger og der bliver forklaret". De bruger metoden walk and talk - En tur i skoven. Læreren hjalp med at få ideen. De fortæller, at alle bakker hinanden op, så gruppen har, kunnet være positiv selvom de har mødt udfordringer. Gruppen strikker og hækler mens de arbejder med deres entreprenørskabsprojekt. (observationsnotater fra innovationsprojekt på GF2)

At samarbejde om samme interesse:

"De siger', at gruppen fungerer godt og, at det har været et rigtig godt samarbejde, hvor der har været enighed om det meste. Hvis de skal nævne et emne som de har været særlig optaget af at forbedre i forhold til hvad de så i deres praktik, så er det børnenes kost, det har fyldt meget. Det gav en masse, og det var muligt at slippe idéer los og tænke ud af boksen". (elevinterview)

Samspilsprocesser i grupper der samarbejder om en fælles opgave:

"Der har været en åbenhed i gruppen over for hinandens ideer. Nu hørte jeg [informant] lige, at der var en anden gruppe, hvor der blev sagt, at alle i gruppen skal være enige før de tager idéen med. Hvor i min gruppe, der har vi valgt at sige, at vi skal have lidt af det hele. Der skal ikke være nogen ideer, der bliver skudt ned. Der er åbenhed i gruppen og åbenheden er rigtig god i forhold til hvilke ting vi skal have med". (elevinterview)

"Når vi skulle lave sådan nogle opgaver om værdigrundlag eller sådan, så sad vi og snakkede om, hvad vi syntes der var vigtigt. Alle sammen kom med alle mulige idéer som vi så skrev vi ned og er så endt med det med det, vi synes vi ville stå inde for. (elevinterview) 
De to eksempler omkring gruppernes samspil i forbindelse med udvælgelse af idéer, er meget forskellige. I det første eksempel er det gruppens oplevelse, at de er åbne over for mulige veje at gå og, at alle skal høres og alle idéer skal med. Gruppen vil ikke kvalificere idéer i første omgang, så de vil have brug for, at der kommer feedback eller forstyrrelser udefra som hjælp til at gruppen kan sortere i antallet af idéer og dermed kvalificere mulighederne for at realisere dele af deres idéer til deres projekt om en ideel institution. Den anden gruppe synes selv at kunne nå videre i kvalificeringsprocessen med at vælge ud, men også denne gruppe kan have brug for, at få forstyrrelse og feedback udefra, for at blive udfordret $\mathrm{i}$, at deres valg ikke blot afspejler behov for enighed og, at de dermed ikke har fået faglig kant på deres idéer.

At samarbejde om entreprenørielle processer, og være i faglig fællesskab med andre om at udvikle fra start til slut, stiller store krav til lærernes didaktiske design og didaktiske handlinger under elevernes læringsproces. I EUD Social og sundhed er, som allerede skrevet, alle de entreprenørskabsprojekter, som indgår i andet blik, tværfaglige projekter, hvor eleverne arbejder kollaborativt i forståelsen, at eleverne har fælles ansvar, skal træffe væsentlige beslutninger sammen om indhold, proces og produkt af deres arbejde og sidst, at deres arbejde er indbyrdes afhængigt. Samarbejde stiller krav om engagement og fastholde motivation til samarbejde - også når det er svært. Eksemplerne viser, at det betyder meget for elevernes læring, at de løbende reflekterer over deres samarbejde og er indstillet på løbende at lære af deres erfaringer og ændre på roller, vaner eller andet, hvis det er nødvendigt.

Billede 5, Didaktisk markør for deltagelsesmåder i entreprenørskabsundervisning: At få feedback, anerkendelse, skub og konstruktive forstyrrelser

Hvad læreres konstruktive forstyrrelser kan åbne for af nye deltagelsesmåder:

"Jeg synes det har været spændende, et meget spændende forløb i forhold til de der forstyrrelser vi har været udsat for. Nogle gange har det også været sådan "Ej! (lærerens navn) ikke lige nu, nu vil jeg godt sidde og skrive". Men det har været spændende det der med at så, skulle vi forstyrres og puttes ind i en lille boble, hvor vi havde en aktivitet eller skulle udfylde noget eller sad og snakkede" (elev interview)

En lærer udfolder sine begrundelser for sine didaktiske greb i forbindelse med et ønske om at få eleverne til at komme dybere og mere kritisk ind til kernen at en kreativ idé.

"De er udfordret på, at de skulle strege alt det ud som de bare havde taget med derude fra (praktikken), fordi opgaven var jo, at de skulle forny det som de valgte ud. Det var virkelig en forstyrrelse, der rykkede, men det blev nogle helt andre [tanker og visioner som karakteriserede] institutioner $i$ anden omgang" (lærerinterview)

Betydningen af anerkendelse:

En elev fortæller i nedenstående citat, hvad anerkendelse gør for hende i relation til at få udviklet mod og selvtillid i sammenhæng med hendes performativitet på uddannelsen. Hun siger:

"Vi arbejder rigtig meget med det at være anerkendende over for hinanden, så man føler at selvom man ikke kan lide at fremlægge, så kan man godt stille sig op og sige noget uden, at der bliver snakket om det eller grint af det. (elevinterview) 
Hun fortæller videre, at deres lærer ofte nævner, at de skal behandle hinanden ordentligt og at han nævner det, er med til at gøre hende tryg. Hun siger til slut, at hun nu har fået så meget mod, at hun nu føler, at hun kan gå ud i institutionerne og gennemfører de aktiviteter, som hun udvikler med sine klassekammerater. Det turde hun ikke tidligere.

Feedback fra de fagprofessionelle fra praksis.

En lærer fortæller, at feedback fra institutionerne under elevernes entreprenørskabsforløb spiller en stor rolle i elevernes læring. De indbygger det i forløbet ved, at eleverne kommer på besøg ude på en institution for at få de professionelles vurdering af deres idéer, før de gennemfører dem. Som læreren fortæller:

"... når de laver noget, så får de feedback, så går de ud og arbejder sammen igen, og så gør vi det igen. For det er dér læringen finder sted... Fordi det er noget med at de går ud og får noget viden de får lov til at bygge op og de får fordybelse og de fär tid til at gøre det” (Lærerinterview).

Ovenstående citat viser, at lærerne kan mærke værdien af den feedback som eleverne får fra institutioner, at det giver eleverne mod til at prøve igen - eksperimentere videre med det som de er i gang med at udvikle.

En elev fortæller om betydningen af at få feedback fra en fagprofessionel fra en institution: "Dem (personalet) der har været der i mange år, de ved jo også godt, hvad deres børn godt kan lide. Så hvis vi for eksempel siger, at vi gerne vil have de store børn i børnehaven. Så kan de jo (personalet) hjælpe meget med en aktivitet ved, at jeg får noget input fra nogen som er vant til at være der. At få feedback om, at ens aktivitet er fuldendt, så du ved, at det bliver en succes på en eller anden måde. Det betyder meget” (elevinterview)

En anden elev udtrykke det således:

"Man kan godt mærke på folk om man har gjort det godt eller ej. Den der ros, det giver mig en lyst til at komme igen. I mit praktiksted fik jeg at vide, at det var godt, det som jeg gjorde. Det gør at jeg får lyst til det fordi jeg bliver værdsat.

"Det der med, at vi kommer ud og viser vores nye aktivitet og vi får noget respons fra dem og de siger "det var rigtig godt at I gjorde det" så kan vi jo bruge det til flere aktiviteter. Og på den måde motiverer det også en til at fortsætte til at finde på de der nye ideer.

Det sidste eksempel viser igen, hvordan feedback på konkrete aktiviteter giver eleverne motivation til at forsætte med idéudvikling, der som aktivitet kræver tilbagemelding fra de omgivelser hvori aktiviteten skal fungere.

En lærer udtrykker betydningen af feedback fra praksis således:

"Det er min hensigt, at eleverne bliver mere opmærksomme og flittige omkring deres projekter eller aktiviteter fordi de kommer ud og skal dele deres idéer med professionelle i den virkelige verden. De kommer til at gøre sig mere umage, fordi de skal ud og sælge en vare. - ... de kommer til at tage nogle ting mere alvorligt " (Lærerinterview)

Citaterne fra eleverne tyder på, at motivationen og engagementet til at gøre en forskel og gøre sig mere umage ikke handler om frygt for praksis, snarer samspil og samskabelse med praksis, hvor fejl og forbedring er en del af den entreprenante læring, der er på spil 
Feedback, anerkendelse og konstruktive forstyrrelse, ser ud til at udvikle alle fire dimensioner inden for kompetencerepertoiret i sammenhæng til entreprenørskab. Det er alle centrale forhold, der skal i spil i sammenhæng til at fremme elevernes aktive deltagelse i læringsarbejdet. Feedback ser ud til at støtte og vejlede eleven, og samtidig motivere til at arbejde videre i skabende processer med at forbedre aktiviteter, produkter eller processer til gavn og værdi for brugere (mennesker) i deres hverdagsliv. Den anerkendende tilgang giver eleverne lyst til uddannelse og mod til mere, og det synes som om eleverne er meget bevidste om, hvad disse didaktiske greb kan gøre for deres læringsrejse fra personlig usikker til mere faglig og personlig sikker, og dermed kan indsigten åbne for elevernes indsigter omkring værdien af deres personlige ressourcer og interesser.

Billede 6, Didaktisk markør for deltagelsesmåder i entreprenørskabsundervisning: At afprøve sine idéer gennem eksperimenter i praksis

Eleverne, der har deltaget i undervisningseksperimenter omhandlende entreprenørskab, giver udtryk for engagement, motivation gennem høj involvering og læring gennem undersøgende og reflekterede handlinger.

At arbejde eksperimenterende, hvor det at designe en aktivitet, at udarbejde en prototype og så prøve den i praksis og efterfølgende gøre den bedre ved at prøve igen, ser ud til at være processer, der får læring til at rykke hos eleverne. En elev udtrykker det således: "At man ved hvad der har været godt og hvad der skulle gøres bedre. Man bliver jo kun klogere af at prøve".

Eller sagt af en anden elev:

"Vi kommer derud (i praksis) og afprøver dem (idéerne) og så kan vi evaluere når vi kommer hjem og se om der er noget vi kan gøre anderledes. Jo flere gange vi gør det, jo bedre bliver det med tiden når vi finder på nye ideer".

Det, at eleverne har mulighed for at omsætte det, der er ofte er sat i gang på skole til nye initiativer i praktikken eller under besøg, ser ud til at betyde, at eleverne oplever en stolthed og en sikkerhed.

"Min vejleder var en meget sød fyr, som var åben overfor, at nu skulle jeg altså lave nogle ting, og der var masser af muligheder. Jeg skulle bare tage nogle børn, og hvis han skulle afsted, så kunne vi sagtens finde ud af det. Så der var åbenhed over for de ting, jeg kom med. Der var ikke nogen der sagde "det er en dårlig idé" der var bare åbne rammer, og jeg kunne få lov til lige præcis hvad jeg havde lyst til"

Eksemplet viser, hvor meget det betyder, at eleven får støtte og anerkendelse til at turde prøve noget, og dermed også til at fejle. Elevens handlekraft og lyst til deltagelse bliver stimuleret af den åbne tilgang hos vejlederen som eleverne møder.

"At skulle gå ud og lave noget som man faktisk ikke helt har prøvet, og som man måske ikke helt ved om virker, det er lidt at gamble, men det er også sjovt at skulle udfordre sig selv lidt. For står man i en situation, hvor børnene (læs også brugerne) ikke synes det er 
sjovt, så skal man være hurtig til lige og finde på et eller andet, som kan gøre det sjovere" (elevinterview)

Eksemplet viser, at eleven skal have modet til at kunne improvisere i uforudsete situationer. Eleven fortæller videre, at læreren er rigtig god til gennem ros og opmuntring, at give eleven det nødvendige mod. "vores lærer kommer med den der motiverende faktor og siger f.eks. "du er mega god!" det har vi alle sammen prøvet at sige. Så på den måde der, så tror jeg man lærer at tænke lidt hurtigere.

"Det er ikke fedt at gå ud og sige "jeg har fundet på legen 'gå i dåsen' den kender alle jo, men at man viser folk en leg eller aktivitet som der er ingen, der har set før, og at den (legen) kan gå hen og blive sjov det er også en succesoplevelse for os. En følelse man får med de der nye aktiviteter og lege, det gør jo, at man bare har lyst til at prøve mere". (elevinterview)

Citatet fra eleven viser, hvor meget det kan stimulere elevens selvfølelse, at skabe en aktivitet, der skaber værdi, der hvor den bringes i anvendelse. Konkrete succesoplevelserne af håndværksmæssig karakter bruges aktivt til elevens egen refleksion, og citatet vidner om høj motivation til at udvikle mere, at handle mere foretagsomt fremadrettet.

Et andet citat fra en elev underbygger ovenstående:

"Ja og så, når du kommer ud i en institution, så kan det være, at dem der arbejder der i forvejen får noget af os (elever) ved, at vi tænker på en ny måde og lave nogle nye aktiviteter ud fra for eksempel et eventyr, eller et eller andet hvor vi laver en bevægelsesleg. På den måde kan vi inspirere dem til at få ideer. Så viser man dem (de fagprofessionelle, der arbejder $i$ institutionerne, at denne her uddannelse den kan bruges til at lære at tænke på denne her måde og igangsætte nyt bare med det vi har. "(elevinterview)

Billedet viser, at skolen og praktikken eller praksis, med fordel kan åbne for skabende aktiviteter, der stimulerer eleverne til at bruge fantasi og kreativitet. Når eleverne arbejder med eksperimenterende aktiviteter, hvor de skal være undersøgende, ser det ud til at engagere eleverne med høj involvering og refleksion over deres handlinger. Det åbner for deres entreprenørielle kompetenceudvikling, at prøve grænser gennem eksperimenter i real life. De eksperimenterende aktiviteter har åbnet for nye deltagelsesmåder, ved at elevernes skabende kraft og risikovillighed bliver sat i spil. - De har hjulpet hjemløse og set hvilken forskel/værdi deres aktivitet har haft. Prøvet kræfter med små eksperimenter, der skaber glæde og nærvær for ældre demente. De har lavet en bog, der kan hjælpe unge med selvværdsproblemer (ung til ung). Og de har skabt aktiviteter for børn i institutioner, som har skabt værdi i form af, for eksempel øget sociale eller motoriske kompetencer.

Elever giver også udtryk for, at de føler sig anerkendt, hvis for eksempel et praktiksted viser eleverne den tillid, at de kan prøve deres idéer af. Det giver ligeværdige faglige relationer mellem elever og fagprofessionelle. At få feedback fra professionelle og se, at der er noget, som kan være anderledes, er med til at give mod og bryde grænser. Den eksperimenterende form ser ud til at stimulere elevernes mod til at turde tro på, at de kan medskabe praksis, og at deres handlinger kan skabe værdi for brugerne (mennesker) og deraf selvtillid til at være konstruktiv usikker og undersøgende. 


\section{Opsamlende}

Billederne viser, hvordan elevernes arbejde med at udvikle aktiviteter til deres målgrupper, og interagerer med omverdenen tager form. Omkring deres aktiviteter ser vi tydeligt, hvordan uddannelsens medie menneske klart kommer til udtryk som omdrejningspunkt for entreprenørskabsundervisning og situeret læring. Elevernes kompetencerepertoire i sammenhæng til entreprenørskab udspiller sig hele tiden omkring mediet mennesker. Det uddannelsesspecifikke, for eksempel børns leg, institutionelle rammer for børn og borgere, betydningen af frivilligt arbejde, teknologiske hjælpemidler til børn, borgere eller personale tillægges betydning, forstået som ramme for iscenesættelse af entreprenørskabsdidaktiske aktiviteter med henblik på at fremme elevernes motivation og læring.

I nedenstående citat er der en elev som fortæller, hvad det betyder for hende og hendes motivation og lyst til læring, at der på social og sundhedsuddannelserne er en særlig pædagogisk tilgang, der er et karaktertræk ved uddannelsen.

"På grundforløbet blev jeg helt bidt af måden at undervise på og måden med at lege sig til læringen og lave så mange anderledes ting. Jeg har altid haft meget svært ved matematik. Dansk har været bedre i form af, at jeg er rigtig god til at finde på historier. Jeg fandt jo ud af, at man ikke behøver at sidde og skrive en matematikopgave for at blive god til matematik, men man kan lige så godt stå op og lege skakbrikker og finde matematikken i det. Det behøver ikke at være så bogligt og så tungt alt sammen. Man kan jo netop have det sjovt imens man lærer. Jeg fandt ud af, at man nærmest ikke mærker læringen komme ind. Vi har det sjovt, mens vi lærer" (citat fra elevinterview - hovedforløb).

\section{EUD Merkantil}

Afsnittet åbner for fortællinger om elevernes deltagelsesmåder i entreprenørskabsundervisning på Merkantil EUD. Det er overvejende symboler og mennesker, som er medie eller genstandsfelt for den erhvervspædagogiske praksis inden for de merkantile uddannelser (Lucas, 2014).

Nedenfor følger beskrivelser af situationer, hvor lærere inden for de merkantile fag har eksperimenteret med at undervise gennem entreprenørskab, og det præsenteres hvilke konkrete intentioner, som underviserne inden for de merkantile fag har haft for tilrettelæggelse af undervisningen gennem entreprenørskab. Som det ses, så knytter undervisernes intentioner an til deres branchekendskab, og det er i denne relation at branchen bliver organiserende for den specifikke undervisning.

\section{Undervisningseksperiment 1: Uddannelsen til kontor-, handels- eller logi- stikelev, EUD Merkantil}

I faget 'Praktikpladssøgning' på GF1 og GF2 på EUD Merkantil er målet med undervisningseksperimentet, at eleverne opnår klarhed over hvilket område, de ønsker som praktik og at, de bliver klar til at søge en praktikplads. Undervisningseksperimentet forløber som del af faget 'Praktikpladssøgning', der som noget nyt er fordelt over både GF1 og GF2. Faget betegnes af læreren som det vigtigste fag overhovedet, da det er afgørende for om eleverne kommer i praktik og i sidste ende for om de fuldfører deres uddannelse.

På holdet er der i alt 26 elever, og en ligelig fordeling af drenge og piger, der aldersmæssigt er mellem 15-18 år. Ifølge læreren dækker elevernes baggrunde "hele paletten af umodne og uafklarede". Nogle har været omkring et gymnasium, andre kommer direkte fra 9. klasse, tre læsesvage elever. Tre elever har været fjernet fra deres familie og har boet enten i en plejefamilie eller på en ungdomspension. 
Eleverne skal vælge arbejdsfelt, enten 'logistik', 'handel' eller 'event' og tilegne sig en forståelse for, hvad en virksomhed forventer af en kommende elev. Eleverne skal blandt andet få viden ved at udarbejde interviewskema, og dernæst udfører de et rollespil hvor de interviewer en potentiel arbejdsgiver om forventninger til en praktikelev.

\section{Lærernes intentioner med undervisningseksperiment omhandlende entreprenørskab}

På forløbet 'praktikpladssøgning' ønsker læreren, at eleverne, i højere grad end hvad hun har erfaring med, udvikler sig personligt og derigennem opnår bedre muligheder for at få en praktikplads. Før lagde undervisningen op til "copy-paste", det vil sige, at eleverne tilpasser en ansøgningsskabelon til deres egen profil. Med entreprenørskab vil hun gerne, at de kommer "ud over rampen". Hun udtrykke sine intentioner således:

"eleverne arbejder med sig selv og skaber en anden fremtid for sig selv ved ligesom at være ude og undersøge: Hvad er det, jeg skal kunne derude? Og hvad er det, de forventer at se i min ansøgning? Fremfor, at det bare er noget en fremmed [læreren] har skrevet [på en PowerPoint]" (Lærerinterview, Merkantil EUD).

Som det fremgår af citatet, har hun en antagelse om, at eleverne bedre kan lære det, de skal, for at blive attraktive for en virksomhed, hvis hun ændrer ved a) rollefordelingen i undervisningen og b) kilden til viden. Eleverne skal i undervisningseksperimentet selv opsøge viden, og i den proces, forventer hun, at den traditionelle rollefordeling mellem lærer og elev ændres, så læreren ikke bare overleverer allerede objektiveret stof til eleven.

Lærerens intention er at arbejde med betydningen af, at det der skal læres, er handlingsorienteret. Hun ønsker at fremhæve, hvad eleverne skal "kunne derude" snarere end hvad de skal vide. Hun (læreren) ønsker, at eleverne får personlige erfaring fra branchen, så den får karakter af at være både en instruktiv og inspirerende kontekst for formålet med undervisningen.

\section{Undervisningseksperiment 2: EUX Handel og Kontor, GF 1}

Undervisningseksperimentet Opstart af eget eventbureau foregår på GF1 EUX, Handel og Kontor, og samler læringsmål fra to fag, henholdsvis "Innovation" og "Metode". I alt forløber undervisningseksperimentet over 60 lektioner, og der er 30 elever på holdet. Forløbet er tilrettelagt med et gennemgående tema, der handler om at starte et eventbureau op fra bunden med alt hvad det indebærer f.eks. finde et navn, designe logo og identificere målgruppe. Eleverne skal ende op med en overordnet konceptbeskrivelse af deres ide. Eleverne skal arbejde i grupper under deres entreprenørskabsprojekt, De finder inspiration ved at snakke med forskellige virksomheder inden for en bestemt branche de selv har valgt, at eventdelen skal rette sig mod.

Under forløbet underviser lærerne så i forskellige faglige metoder, (jf. læringsmålene for fagene) som har betydning for opstart af egen virksomhed, som for eksempel GANT, AIDA, og brainstormmetoder. I dette tilfælde handler det altså om faglig undervisning i forståelse og brugen af GANT diagrammer som planlægningsværktøj. Den konkrete undervisning i f.eks. Gant diagram, er fokuserede faglige timer, hvor læreren gennemgår og forklarer, og der er ikke nødvendigvis direkte link til elevernes entreprenørskabsprojekt. Lærerne har tilrettelagt det sådan, at eleverne, kan overføre de forskellige projekt og innovationsmetoder til deres eget entreprenørskabsprojekt om opstart af et eventbureau, efter behov. I den observerede situation, arbejder eleverne med tidsstyring i relation til en fiktiv case, der omhandler opstart af virksomhed med egen pølsevogn. Eleverne skal gennem brug af GANT diagram tilrettelægge aktiviteter i forbindelse med opstart af pølsevognen. Eleverne får allerede beskrevne aktiviteter, som de skal placere i diagrammet. Det er under observationen ikke alle elever, der ser ud til at koble opgaven til deres eget projekt. 


\section{Lærernes intentioner med undervisningseksperiment omhandlende entreprenør- skab}

Det er lærernes intention med et tværfagligt entreprenørskabsforløb "opstart af eget eventbureau" at samle fagene innovation og metode med entreprenørskab, som en overliggende tematik. Lærerne er af den oplevelse, at jo tidligere, at eleverne prøver kræfter med iværksætteri og får personlige oplevelser med det, jo bedre, da eleverne på GF1 EUX, EUD Merkantil ikke umiddelbart ser en sammenhæng mellem deres uddannelsesvalg og så iværksætteri i form at opstart af egen virksomhed. Lærerne ønsker, at eleverne på flest mulige områder kan stifte bekendtskab med de arbejdsformer og krav, der er til at arbejde entreprenant og skabende.

Formålet med besøg ude i forskellige typer virksomheder som målgruppe for et eventbureau, er, at eleverne får viden, så deres idéer til events har afsæt i autentiske behov. Fokus for forløbet er således at udvikle elevernes kompetencer til at etablere kontakt og have dialog med omverden, da læreren udtaler, at det er entreprenørielle kompetencer de vil få brug for i mange forskellige sammenhænge i deres arbejdsliv. Læreren udtaler, at der er forskel på hvor trygge eleverne er ved at tage kontakt til omverden, og at dette hænger sammen med de enkelte elevers mod, lyst, og følelse af at bidrage med noget i eksempelvis den butik de har været ude at tale med.

Eleverne skal på kollaborativt vis arbejde sammen om opgaven i grupper, som er sat af læreren. Der er i alt fem grupper. Underviserens tanke med forløbet er at introducere eleverne til at starte egen virksomhed. Han underviser gennem entreprenørskab. For underviseren handler det om at give elever lyst til at starte egen virksomhed:
"... når jeg introducerer det her for eleverne, om at starte virksomhed og om det er noget de kan forstille sig, så er de meget sådan: "Neej" og sådan tvivlende, og hvad indebærer det. [De spørger]: "Virksomhed... hvad er en virksomhed?" [Jeg svarer]: "Det kan være en produktion, butik, det kan være" [De siger]: "Nåh". Der skal etableres et grundlag for overhovedet for at kunne vurdere, om man har lyst til at starte en virksomhed" (Lærerinterview, Handel og kontor)

Af citatet fremgår det, at underviserens ønske er at give eleverne lyst til at være produktive og starte egen virksomhed. Den pædagogiske strategi er ifølge citatet at "etablere et grundlag", og observation og interview viser, at grundlag af underviseren forstås som teoretisk viden om etablering af virksomhed i form af viden om faktorer som målgruppe, virksomhedsformer og budget, som forudsætning for entreprenøriel handling - forstået som produktiv og materiel aktivitet. Det er tanken, at eleverne undervejs i forløbet overfører den viden, de får, til arbejde med opstart af eget eventbureau.

\section{Undervisningseksperiment 3: EUD og EUX Merkantil, GF 2}

Undervisningseksperimentet forløber i faget matematik på GF2. Eleverne skal som del af undervisningsprocessen selv undervise elever fra folkeskolens 9 . klasse i matematik, og mere specifikt i emnerne parabler og andengradsfunktioner. Den observerede klasse tæller 22 elever, 16 piger og 6 drenge. Aldersmæssigt er de fleste omkring tyve år, der er dog enkelte sidst i tyverne/først i trediverne. For nogle er uddannelsen omskoling. En enkelt elev i denne klasse er tosproget.

Der er afsat 22 lektioner til faget, samt en dag til undervisning af en 9. klasse (workshop) og en dag til præsentation af resultatet for et lokalt, kommunalt matematiknetværk. Kompetencemæssigt er eleverne spredt i matematik. For nogle er det en udfordring blandt andet fordi det er mange år siden, de sidst har haft matematik, mens det for andre er ligetil. 


\section{Lærernes intentioner med undervisningseksperiment omhandlende entreprenør- skab}

I matematikundervisningen på HG og EUX forestiller læreren sig, at entreprenørskabsundervisning kan gøre det lettere for eleverne at tilegne sig svært stof, hvis hun gør anvendelse af matematik til en del af undervisningsprocessen. Det er samtidig implicit for denne lærer, at entreprenørskab handlede om at skabe værdi for andre, hvilket hun har omsat til et eksperiment, hvor hendes elever underviser 9. klasse elever. Denne underviser har fra tidligere klasser erfaring med at eleverne, selv ved eksamensbordet, ikke har forstået funktionen af parabler og andengradsfunktioner. Læreren har en antagelse om at formidling af matematik til andre, kan være en måde at give eleverne viden "på en anden måde", som kan forstærke deres læring af svært stof:

"at tænke entreprenørskab [i matematik] så er vi faktisk ude $i$, at de skal undervise andre for at, vi kan tænke entreprenørskab [...] [jeg tog] parabler og andengradsfunktioner netop fordi, det for mig at se ... er det sværeste, fordi så skal jeg prøve at få dem til at tage det ind på en anden måde, for de forstår det ikke" (Lærerinterview).

Det er interessant, at underviseren har et tydeligt værdiblik i sin forståelse af entreprenørskab. I dette tilfælde som noget, der skaber værdi for andre. Hun kobler mellem en værdibaseret forståelse og konkret anvendelsesblik i form af formidling af stoffet til andre elever, som en læringsaktivitet, der giver stoffet mening i kraft af den værdi formidling af det, til andre har - og derigennem individuel læring.

\section{Didaktiske billeder på elevernes deltagelsesmåder}

Dette afsnit vil i forlængelse af ovenstående tre undervisningseksperimenter, i billeder belyse, hvilke didaktiske greb, som ser ud til at åbne for elevernes deltagelse i undervisning gennem entreprenørskab i Merkantil EUD og dermed vurderes at have betydning for elevernes motivation og læring. Hvert billede indledes med en didaktisk markør for entreprenørskabsundervisning, hvilket betyder, at markøren knytter sig til didaktiske greb af betydning for, at eleverne udvikler entreprenørielle kompetencer. Disse billeder er fra observationer og interviews.

Billede 1, Didaktisk markør for deltagelsesmåder i entreprenørskabsundervisning: At skifte perspektiv gennem nye roller og identifikation med modtager

På tværs af fagene forsøger underviserne i de tre undervisningseksperimenter at situere elevernes læring i andre kontekster end skolens.

Når man ikke er fortrolig med matematik og ej heller med formidling, kan det virke skræmmende at skulle undervise andre. For nogle elever har det virket som et krav, der lå ud over, hvad de kunne se sig selv imødekomme. De gjorde det alligevel, fordi det var en del af undervisningen. Det fortæller en pige om i citatet nedenfor. Heraf fremgår det også, at mødet med 9. klasses eleverne har bygget bro over den barriere hun har skabt i relation til billedet af hende selv som en, der ikke underviser. "Broen" opstod i kraft af umiddelbar identifikation med målgruppen, som hun genkendte som en yngre udgave af sig selv - og tilmed både ufarlige og forventningsfulde:

"... For mig som person, så synes jeg det var overskridende at skulle undervise en 9. klasse. Det havde jeg bestemt ikke lyst til. Jeg satte mig på bagben og 'nej, det skulle jeg godt nok ikke'. Men det var med i vores undervisning og så tror jeg bare eleverne, de er ikke som jeg tænkte dem.

I: Nej? Hvordan tænker du? 
Elev: Jeg tænkte det var mig selv, sådan en lille rod i 9. klasse, der kom herog de er da meget søde.

I: De er sødere end du havde regnet med, de samarbejder?

Elev: Ja, men det er dét, de er kommet for at lære noget”. (Elevinterview)

Erfaringen af, at elevtyper, hun genkender, er kommet for at lære noget, skaber en ny kontekst for eleven og den samtidige, overraskende identifikation med opgaven og samspillet med eleverne (Illeris, 2006) styrker motivationen til at deltage i undervisningsprocessen som underviser, og fra denne position lære matematik. Samspillet med 9. klasses eleverne påvirker $\mathrm{HG}$ elevens læringsmuligheder i den konkrete situation.

Læringen forankres gennem situeretheden i positionen, som underviser for andre elever i forholdet mellem selv som elev og i rollen som underviser, og tilegnelse af det faglige stof. Indholdet af HG undervisningen integreres i elevens personlige udvikling med positiv effekt. Undervisning af andre elever og disse elevers respons giver HG eleverne nyt perspektiv på dem selv og indholdet i undervisningen - de ellers abstrakte tal bliver noget, andre kan bruge og som det dermed har værdi at kunne forklare dem.

Et andet eksempel på denne identifikation og perspektivering ses i eksemplet med 'praktikpladspladsøgning', hvor en central pædagogisk aktivitet er rollespil. Eleverne arbejder i flere lektioner med udvikling af forestillinger og perspektiver på arbejdsgiveres ønsker til elever ved at sætte sig i arbejdsgivernes sted. Underviseren har arbejdet med KIE modellen, som rammesætter tre procesrum $\mathrm{K}$ for kreativitet, I for innovation og $\mathrm{E}$ for entreprenørskab og underviseren har planlagt aktioner, der lægger sig op ad den.

Eleverne udfylder post-its til temaerne "Hvad nu hvis jeg var rig" og "Hvad nu hvis jeg var fattig" og senere om "hvad nu hvis jeg var chef". Alle bidrager - nogle kommentarer er ikke stavet rigtigt, men det kommer der ikke bemærkninger fra elever til andre elever om. Eleverne går smågrinende op til tavlen og sætter deres sedler op, og der en glad stemning $\mathrm{i}$ klassen.

Da læreren en uge senere interviewes, og intervieweren refererer til denne observation af intens, fysisk og lydlig elevaktivitet, nikker hun og siger at ja, "der skete noget", "de kom op af stolene".

Hvad-nu-hvis øvelserne er identifikationsøvelser, men undervisningsformen, hvor eleverne skriver noter på post-it og går op og sætter dem på en plakat, har betydning for deres læring. De oplever sig selv - og bliver oplevet af læreren - som deltagende i kraft af deres gåen-rundt og sætten-sedler-på-tavlen.

Formen på undervisningen har betydning. I forløbet omkring 'Opstart af egen virksomhed' beder læreren eleverne udarbejde en plan for tidsstyring af aktiviteter i forhold til en fiktiv virksomhed og i et andet tilfælde skal de foretage interview med kategorier af detailhandelen, som er bestemt af læreren - for eksempel møbelvirksomheder. Nogle elever brokker sig over, at de ikke selv har måttet vælge type af virksomhed i forhold til interview, fordi de mener, de ville være mere motiverede for at designe interviews med en virksomhed, de allerede interesserede sig for. En elev siger for eksempel: 
"Jamen for eksempel vi havde møbelbutikker, det interesserer mig jo ikke, fordi sådan noget går jeg jo ikke op i. Så hvis nu jeg havde fået, måske tøjbutik eller... Nu vil jeg rigtigt gerne selv sidde i et forsikringsselskab, hvis nu vi havde fået noget vi havde interesseret os for, så havde det måske været lidt federe at skulle ud og høre om" (Elevinterview)

Man kan måske sige, at her har eleverne fået et perspektiv at arbejde med, i højere grad end, at de selv har været deltagere i en proces, der kunne udvide deres perspektiver på, hvor de kunne arbejde i fremtiden. Læringen ser ud til at rammes af en identifikationsbarriere i det eleverne ikke udviser samme engagement i opgaver kontekstualiseret i et arbejdsfelt, de ikke ser sig selv i.

Da eleverne omvendt får lov selv at vælge den branche de skal arbejde med, udtaler en elev:

"Jamen, vi kan alle sammen meget godt lide tøj, det er jo udbredt blandt unge. Og nu har vi alle sammen være nede i [butikkens navn] og har købt tøj, fordi det er lidt i den højere ende af end hvis du for eksempel går i H\&M. Og så synes vi, at det kunne være fedt at lave en kollektion med dem" (Elevinterview, Handel og kontor).

I citatet kommer det til udtryk, hvordan det har været motiverende for eleverne at tage udgangspunkt $i$ deres personlige interesser, $i$ et emne som de kan identificere sig selv med.

Forestillinger om det at være selvstændig som en funktion, der kræver overblik og styring af mangfoldige processer, bliver for denne underviser et billede på, hvad eleverne skal kunne præstere for at lykkes. Samtidig bliver det et organiserende element, som former undervisning som forberedelse til elevers senere arbejde med opstart af egen virksomhed. Der er altså tidsmæssig forskydning mellem præsentation af teori og øvelser/opgaver som forberedelse og elevers brug af stof - det som skal læres - i relation til eget projekt.

Ifølge læreren så er formålet med dette undervisningseksperiment, at give eleverne et realistisk billede af, hvad det vil sige at starte egen virksomhed og at være entreprenant, og derved også at nuancere det glansbillede af historier om iværksættere, som hurtigt har fået kæmpe succes. Læreren udtrykker det som følger:

"det at være entreprenant, det kan man også være i det almindelige job. [...] Eleverne skal lære den entreprenante evne, sådan så når de får et lønmodtager job, så kan de få ideer eller de kan vurdere ideer og de kan handle på deres ideer". (Lærerinterview).

Billede 2, Didaktisk markør for deltagelsesmåder i entreprenørskabsundervisning: At skabe mening for eleverne med undervisningen

Eleverne deltager, når undervisningsprocessen giver mening. Fokus på sociale sammenhænge mellem det, der formidles i undervisningen og brugskontekster, situerer elevers læring, i kraft af det de gør i meningsgivende sammenhænge. 
I eksperimentet 'praktikpladssøgning' viser observationen, at læreren afsluttede post-it øvelser med opsamlinger i plenum - men uden at korrigere de svar, eleverne havde givet. Hun sagde for eksempel: "Her er en masse om selvstændighed... hvad tænker I om det?", hvortil en elev svarede, at det var vigtigt selv at kunne se opgaver, så man ikke hele tiden skulle have at vide, hvad man skulle gøre. Elevudsagnet blev taget alvorligt i kraft af at læreren spurgte ind til det. Man kan sige, at eleverne bliver medskabere af indholdet, gennem lærerens videreudvikling af undervisningsprocessen, gennem deres pointer.

I eksperimentet med matematikundervisningen, hvor den centrale læringsaktivitet var undervisning af andre elever oplevede læreren, at eleverne i langt højere grad deltog netop fra traditionelle elevpositioner. Det vil sige som lyttende subjekter i en tavleundervisningssituation og aktivt noterende:

"... men det jeg synes der er mest interessant, det er, at jeg aldrig nogensinde [har] set dem tage så mange notater, som de har taget under det her eksperiment. Så det er måske det, at de skal undervise en 9.klasse. Det er måske nu de skal prøve at erfare, at hvis ikke de kan huske det, så er det måske en god idé at notere det ned. Der har været noteret ned som aldrig før i det her [forløb]. Det synes jeg var interessant at se. Der var ingen der gik ud af klassen, og det er der ellers ret tit, men der var ingen, der gik ud uden, at de havde skrevet nogle ting ned" (Lærerinterview).

Koblingen af den praktiske, elevengagerende opgave ser ud til at have skabt øget læring i kraft af det eleverne gør.

Læreren har også set tegn på, at den anderledes undervisning har givet eleverne en bedre faglig forståelse:

"... jeg har oplevet, at de [eleverne] rent faktisk har mere styr på [matematiske emner], end de tidligere har haft. De har mere styr på hvad det er for nogle forskellige egenskaber en parabel har og det med toppunkt og nulpunkt, det har de optaget på en helt anden måde denne her gang, i forhold til sidste gang" (Lærerinterview)

Læreren ser, at eleverne har "optaget" abstrakte teori om matematiske emner på en ny måde gennem en entreprenøriel undervisningsproces. Den umiddelbare anvendelse af matematikken i en brugskontekst, har gjort emnet anvendelsesorienteret og dermed håndgribeligt for eleverne og det har styrket deres læring og motivation.

Lignende de to andre eksempler, så udtrykte eleverne i undervisningseksperimentet om "Opstart af egen virksomhed" vigtigheden af at kunne se mening i opgaverne. En elev udtalte for eksempel:

"Jeg vil sige, at jeg er typen som, hvis jeg får en opgave, som jeg synes jeg ikke kan bruge til noget, så synes jeg, at den er åndssvag. Så hvis jeg for eksempel får en opgave om at ringe til en virksomhed, så har jeg det sådan 'jeg skal ikke bruge det til noget, så hvorfor skal jeg lave det?" (Elevinterview).

Samme elev fortsætter: 
" [...] hvis man nu sidder og synes, at det er en åndssvag opgave og, at det ikke giver nogen mening, så det at komme ud og lave den, det gør, at man måske får en positiv holdning til det, fordi man har det sådan 'okay, det er faktisk meget sjovt det her', og at det nu giver mening at lave et budget, for ellers går det fuldstændigt $i$ kaos eller andre ting" (Elevinterview).

\section{Billede 3, Didaktisk markør for deltagelsesmåder i entreprenørskabsundervisning:} At eleverne er medaktør i formulering af læringsindhold

For nogle elever kan lærerens autoritet og den relaterede envejskommunikation være en udfordring for læring. I faget praktikpladssøgning blev eleverne, som allerede nævnt, aktivt inddraget som aktører. For nogle elever åbner det for nye læringsrelationer, hvilket styrker deres muligheder for læring:

"Hvis jeg skulle sidde ved en computer og tænke helt selv, så ville jeg gå i stå på et tidspunkt fordi jeg ikke ville tænke alt det igennem, som der stod (på plancher med post-its med andre elever forslag til spørgsmål, man kan stille $i$ et interview). Hv-spørgsmål... Jeg ville have nået et par stykker og så ville jeg gå i stå. Så ville jeg tænke, hvad skal jeg skrive nu? Men fordi jeg selv skulle lave nogle [post it] og så kigge på andres, så fik man større indblik over hvad man rent faktisk kunne finde på at spørge en chef om" [...] "Jeg synes, det er fedt at høre en andens [elev] ide eller spørgsmål" (Elevinterview,).

Eleven mener, at der er stor forskel på at skulle sidde alene og selv tænke sig frem til hvordan et rigtigt interview skal formuleres og at skulle være aktiv aktør i formulering af indholdet $i$ et interview. Eleven giver udtryk for, at det hjælper at se og høre, hvad andre tænker. Fokus i undervisningen forskydes for eleven fra 'gør jeg det rigtigt' til 'hvad kan man gøre', og det ser ud til at stimulere deltagelse og dermed læring.

Betydning af hvorvidt elever passiveres eller inddrages som aktører i undervisningsprocessen uddybes:

"Du går i stå, hvis du skal sidde stille for dig selv. Jeg tror ikke, jeg er den eneste i klassen, ... der er mange flere, der kommer til at stå stille, hvis hun [læreren] bare fremlægger og så skal vi derefter i gang med at lave opgaver... Så kommer folk til at sidde ved deres skærm og halvdelen af klassen sidder med hånden oppe. Men det har der jo ikke været nu, efter vi har provet tingene sammen, så har jeg kunnet sidde ved min computer og lave det hele selv" (Elevinterview).

Eleverne italesætter, hvad det betyder at arbejde med konkrete opgaver og finde på indhold, replikker sammen med de andre elever, som så kan indgå i et interview.

Interviewudsagnene oven for viser, at den sædvanlige lærer-til-elev kommunikation efterlader disse elever sårbare. Vi hører samtidig, at det ikke sker efter denne undervisning. De kan godt skrive en ansøgning selv på en computer - præcis som det sædvanligvis kræves. Forskellen er den praktiske proces inden, hvor, som en elev siger ovenfor: "vi har prøvet tingene". 
I praktikpladssøgning har drengene også, som noget nyt og uventet opdaget, at man kan lave en ansøgning på flere måder: "en ansøgning, den har jeg fundet ud af, at man kan lave på flere måder $i$ stedet for bare at skrive en ansøgning" (Elevinterview).

Drengens refleksion kan fortælle om, at den sædvanlige tavleundervisning efterlader et indtryk af, at det læreren fortæller fra sin position ved tavlen med front mod eleverne er sandhed. Det vil sige, at den gode ansøgning er en ansøgning som ligner den, læreren præsenterer i sin PowerPoint. Her, i denne undervisning, er der sket noget andet. Og eleverne opfanger, at de elevinddragende processer ikke alene er læremidler, der skal effektivisere læringen, men at formålet er et andet og i dette tilfælde er resultatet, at de lærer noget andet. De har lært, at det ikke handler om at skrive den rigtige ansøgningen ift. en skabelon, men om at skrive sin egen ansøgning ift. en række proceskriterier. Drengenes refleksion er overensstemmende med lærerens erfaring med, at nogle elever er overraskede over, at de har fået lavet et interviewskema med "et ret godt indhold".

Den aktivitet, som I særlig grad har gjort en forskel er ifølge læreren er den, hvor eleverne skal designe spørgsmål:

"Der er meget højere elevaktivitet - det gør, at de har et andet engagement i det. [...] De bliver tvunget til at tænke nogle problemer på en helt anden måde. Det tror jeg også de [eleverne] selv kan mærke, er en tilfredsstillelse" (Lærerinterview).

\section{Opsamlende}

Opsamlende ser vi, at de tre undervisningseksperimenter inden for Merkantil EUD, fortæller om brug af entreprenørskab som didaktisk greb, der har til hensigt at fremme a) tilegnelse af stof og personlig udvikling gennem identifikation, b) læring gennem værdibasering og c) udvikling af elevfantasi og herigennem meningstilskrivelse af undervisningsindhold (opstart af egen virksomhed). Faglig udvikling gennem identifikation er til stede i alle tre undervisningseksperimenter, dog mest omkring praktikpladssøgning og opstart af egen virksomhed, og det er måske interessant at bemærke, i relation til kontorelevers fremtidige arbejdsfunktion som medarbejdere i en virksomhed, snarere end som virksomhedsejere. De tre eksempler inden for det merkantile område, har givet os eksempler på undervisning, hvor lærerne forsøger at operationalisere læringsmålene gennem entreprenørskab.

\section{Afrunding på andet blik}

Entreprenørskabstænkningen har afstedkommet, at lærer-viden-elev forholdet former sig på nye måder. Undervisning, som har elevernes selvstændige handling i fokus, gør at eleverne i udgangspunktet er tættere på den viden, de har brug for, idet de ikke behøver læreren som formidler af viden. Lærerens rolle forskydes og giver så at sige plads til mere direkte elev-viden relationer. Det stiller samtidig nye krav til lærerne, om at rammesætte elevernes læreprocesser også i relationer, der rækker ud over klasserummet og involverer andre aktører.

Entreprenørskabsperspektivet ser ud til at udvide læringsmiljøet - eleverne lærer i relationer, som strækker sig ud over klasserummet. I de fleste eksempler bliver klasseværelset en slags platform for aktivitet, der rækker ud over skolen - ud til en anden skole eller ud i virksomheder eller endog til fremtidige brugere eller kunder.

Et forhold som vi vurderer spiller en stor rolle i den sammenhæng er, at entreprenørskabsperspektivet tager afsæt i elevernes overordnede uddannelsesvalg og dem med interesse. For eksempel elevenes interesse i og omkring mennesker i en SOSU-uddannelse eller arbejdet og udvikling med fysisk materialitet $\mathrm{i}$ en teknisk uddannelse, og netop det forhold synes, at tænde et særligt engagement og en lyst til uddannelse hos eleverne udtrykt gennem elevernes motivation 
til at engagere sig i den undervisning, som lærerne har gennemført i regi af et undervisningseksperiment.

Når eleverne deltager på nye måder, og deltager i undervisningen gennem nye læringsrelationer, så ændres lærernes rolle og de opgaver, der knytter sig til den nye rolle, i dette tilfælde som facilitator og vejleder mere end som formidler af viden.

Vi har søgt at vise, hvordan elevens motivation og læring påvirkes gennem lærernes didaktiske greb for at skabe deltagelsesmuligheder. Det er her interessant at se, hvordan eleverne gennem mulighed for at deltage på nye måder, ved for eksempel i højere grad at være aktive og medbestemmende på indhold og form, faktisk udviser og tager medansvar i undervisningenhvilket samtidig synes at understøtte motivation og læring.

\section{Tredje blik - Didaktiske billeder på hvordan elever med særlige udfordringer, kan profi- tere af undervisning gennem entreprenør- skab.}

Med afsæt i dels en forståelse af, at entreprenørskabsundervisning sigter på, at elever opnår handlingsorienterede kompetencer, samt evnen til at handle entreprenørielt og foretagsomt, har det tredje analytiske blik til hensigt at svare på den del af forskningsspørgsmålet, der omhandler, hvorledes elever, der har særlige udfordringer, kan profitere af denne form for undervisning.

Med 'profitere' skal, jf. forstudiet (Day, Larsen og Sørensen 2016) forstås, hvorvidt entreprenørskabsundervisningen understøtter motivation og læring. Det analytiske blik, hvordan elever med særlige udfordringer kan profitere af undervisning gennem entreprenørskab, vil primært forholde sig til elevernes egne udtalelser om udbytte af undervisningen (præciseres nedenfor). Sammenhæng med motivation og læring sker ved en efterfølgende sammenfatning og afrunding, belyst gennem de tre forskellige analytiske blik.

Om de fagligt udfordrede kan siges, at de elever, der har deltaget i interviews til denne analyse, enten er udvalgt af deres lærere som udfordrede elever på det hold, som læreren underviser, eller eleverne har selv meldt sig. Afsnittet bygger på udsagn fra elever, som går i normalklasser på EUD. Vi kender ikke lærernes konkrete kriterier for valg af elever til interviews. Det fremgår desuden af interviewene, at eleverne typisk ikke ser sig som udfordrede i deres igangværende uddannelse, men de beskriver tidligere uddannelseserfaringer/folkeskolen som steder, hvor de oplevet sig som udfordrede.

I det følgende gives eksempler på, hvorledes eleverne selv forstår det at være udfordret. Disse synes at understøtte ovenstående, om at udfordrethed typisk tales frem ift. tidligere negative skoleerfaringer.

Dette ses eksempelvis ved at udfordrethed fortælles af en elev som 'ikke at gider folkeskole' 'at skulle sidde og skrive og regne, det er ikke mig'. Samme elev fortæller, at han i folkeskolen fik at vide, at han ikke blev til noget. Med 'blive til noget' fortæller han, at det handler om at være som de kloge hoveder, der stræber efter 12-taller. Det syntes for ham umuligt at opnå. Han fortæller videre, at han på 10.kl. efterskole har lært at skrive og læse trods ordblindhed - og det fortæller han, har givet ham tro på, at han kan klare udfordringer. Udfordrethed tales også frem ved, at en elev siger, at hun godt kan 'lide denne skole' (SOSU-skole), fordi man her får lov til at komme ud og prøve tingene i stedet for 'kun at sidde og lave teori. 
Andre udfordringer som nervøsitet ved fremlæggelse og at sige noget foran andre tales frem af eleverne. Denne fremstilling af udfordring, er modsat ovenstående, knyttet til elevens igangværende uddannelse. Forståelser af udfordrethed er således, fra et elevperspektiv mange facetteret.

\section{Hvordan kan elever med særlige udfordringer profitere af entreprenørskabsundervis- ning?}

Som beskrevet i sammenfatningen for billeder på elevernes deltagelse, har lærer-viden-elev forholdet formet sig på nye måder i de udvalgte undervisningseksperimenter. Vi ser de samme tendenser, når vi fokuserer på de udfordrede elevers oplevelse og deltagelse i entreprenørskabsundervisning. Elevernes selvstændige handling er også i fokus her og det gør, at eleverne i udgangspunktet er tættere på den viden, de har brug for, idet de ikke behøver læreren som formidler af viden. Lærerens rolle forskydes, og giver så at sige plads til mere direkte elev-viden relationer.

\section{Billede 1, Didaktisk markør for udfordrede elever i entreprenørskabsundervisning:} At sikre ligeværdige relationer mellem lærer og elev

En elev fortæller, at det var rigtig rart, at lærerne ikke er "højere stillede, de var ligestillede". Eleven fortæller, at det handler om, at man kunne sætte sig ned og "snakke som at vi er to mennesker". På spørgsmål fra interviewer svarer hun bekræftende på, at det betyder, at hun kan være ærlig, og tør gå til læreren med et problem, fordi læreren er åben over for de ideer hun har og de ting hun siger.

Dette kan ses som en relation, hvor læreren er i øjenhøjde med eleven, og indgår i en kollegalignende og mere uformel relation, hvor begge positioneres med lige mulighed for at ytre sig Ikke kun om faglige temaer, men også temaer af mere privat karakter. Det er tydeligt, at eleven ser netop denne relation som givtig for hendes tryghed $i$ at henvende sig til læreren, og til at bruge læreren som støtte i læreprocesser.

En elev taler om "frihed under ansvar" og fortæller, at hun er sådan "én, der er meget, meget glad for at tage ansvar og hun fortæller, at det "gør, at jeg har lyst til at lære, og ... lyst til at komme $i$ skole og ... lyst til at blive her tre timer mere, end jeg havde lyst til i folkeskolen". Generelt fremhæver eleverne i interviewene især frihed under ansvar som særligt engagerende. Eksemplet her kan ses, som et billede på betydningen af åbne og tillidsfulde relationer mellem eleverne og lærerne, idet der er tale om at, de traditionelle, mere formelle roller mellem elev og lærer brydes, ved at eleven får mulighed for at tage ansvar.

En gruppe af elever bliver spurgt til, hvad det er, der gør, at de lærer mere i denne form for undervisning (entreprenørskabsundervisning). Til det svarer to af dem: Du får hjælp, hvis du spørger. Hvis vi har spurgt, så har han ikke sagt præcist, hvad vi skulle gøre, men mere noget med: tænk i de her baner.". Det er interessant, at eleverne tydeligt kan udpege lærerens konkrete ageren for eksempel i måden, at ikke-svare på. Det synes således, at eleverne vægter en relation med læreren, hvor de har medansvar for at skaffe sig nødvendig viden (for eksempel gennem spørgsmål til læreren), til at kunne løse opgaverne-altså en situation, hvor læreren bevidst gennem sine åbne spørgsmål lukker op for elevens medinddragelse gennem refleksion og dermed motivation. 
Billede 2, Didaktisk markør for udfordrede elever i entreprenørskabsundervisning: At opbygge relationer gennem samarbejde om opgaven i gruppearbejde

Generelt beskrives gruppearbejde af kollaborativ karakter af eleverne som arbejdsmåder, der kan udviske faglige og sociale forskelligheder. Elever fortæller, at gruppearbejde virker bedre end individuelt arbejde, fordi man bliver skubbet lidt ... og ikke bare skal stå alene med det ... at man kan have en hjælpende hånd. De fortæller også, at hvis man har svært ved det faglige, så kan gruppearbejdet gennem en fælles opgave, minimere disse. Eleverne ser gruppearbejde, som et sted, hvor man skal yde. Det er indgangsbillet til gruppen, at man tager gruppearbejdet seriøst, og det dur ikke, at man siger det kan jeg ikke. De ser gruppearbejde, som et sted, hvor de bruger hinandens forskellige kompetencer - og man derigennem kan lære af hinanden. Men det kræver af den enkelte, at man er åben for at lære og bidrage til samtalerne, og selv kommer med nogle input. En elev fra EUD social og sundhed fortæller: "Det er jo tit, hvis man skal være sammen med én, der ikke er så faglig stærk, så kommer de med en skide god idé og så propper jeg bare nogle store ord på, og så fungerer det ligesom bare”. Eleverne stiller altså krav til hinanden i grupperne om at bidrage med værdi til den opgave, der skal løses, deltage og yde. Hvis man kan det, så er der stor villighed til at lære fra sig og hjælpe hinanden.

Nogle elever udtrykker, at gruppearbejdet i denne form for undervisning, er anderledes end andet gruppearbejde og det fremgår, at det, at være sammen med andre om selvvalgte opgaver fremfor bare at skulle løse en opgave sat på forhånd, fremmer engagement. Elever i et fokusgruppeinterview reflekterer her:

"Det hele er helt nyt. Det var helt nyt hvad APPS var. Jeg har lært, at jeg kan meget mere end hvad jeg har troet, set nye sider af mig selv. Fået mere lederegenskab [...] man har lært at tage mere ansvar også... for en gruppe, eller for to personer. Og også være god til at sige, i dag skal vi lave det her, og det her, og det her, i stedet for bare at sige, at vi skal komme i gang" (Elevinterview, IT-supportuddannelse)

I ovenstående eksempel ser vi, at eleverne selv er tydelige omkring forskellige typer af gruppearbejde (fælles opgaver og selvvalgte opgaver frem for individuelle opgaver og givne opgaver), hvor eleverne klart foretrækker fælles opgaver og selvvalgte opgaver. Brug af gruppearbejde som didaktisk greb, kategoriseres her som en åben form, hvor eleverne har stor medindflydelse. Som en rollefordeling mellem elever og lærere, hvor elevernes selvigangsatte aktiviteter i gruppearbejdet bliver styrende - lærerens rolle bliver i højere grad, at trække sig i baggrunden og være mindre styrende, for at give plads til elevernes selvigangsatte aktiviteter.

Samlet set ser det ud til, at arbejdet med opbrud af de traditionelle roller mellem lærer-elev gennem mere elevstyrede forløb, hvor læreren træder et skridt tilbage, fremmer elevernes engagement. De tidligere nævnte aspekter ved entreprenørskabsundervisning som mulighedsorienteret, eksperimenterende, innovativ og samskabende (Lackéus, Lundqvist \& Williams-Middleton, 2015), rummes i disse eksempler og det synes at vise, at det klart fremmer elevernes deltagelse og engagement.

Billede 3, Didaktisk markør for udfordrede elever i entreprenørskabsundervisning: At arbejde med dynamisk og åbent indhold rettet mod praksis 
Om at komme ud i praksis med nye ideer, fortæller eleverne, at:

"ja, og så når du kommer ud $i$ en institution, så kan det være, at dem der arbejder der i forvejen får noget af os ved, at vi tænker på en ny måde og laver nogle nye aktiviteter ud fra, for eksempel et eventyr, eller et eller andet, hvor vi laver en bevægelsesleg. Og så på den måde inspirere dem [praktikstedet] til at få ideer ... Så viser man dem, at denne her uddannelse, den kan bruges til at lære at tænke på denne her måde og igangsætte bare med det vi har ... I mit praktiksted, der fik jeg at vide 'det var så godt det du gjorde der', man får lyst til det, fordi man bliver værdsat" (Elevinterview, PAU).

Eleverne fortæller her videre om, at når man finder ud af, man kan mere end man troede, så oplever man færre begrænsninger. 'Når man altid får lov, også får lov til at prøve noget nyt og få lov til at tænke selv uden at der er nogen, der skal tænke for dig'. Eleven fremhæver, når man lærer nye aktiviteter og lege, så giver det lyst til at prove mere og på at fremføre og vise det man kan. Om nyt og ukendt fortæller eleverne, om det, at skulle gå ud og prøve at lave noget, som man faktisk ikke har prøvet og som man måske ikke helt ved om virker; det aktiverer en usikkerhed - italesat som at gamble. Samtidig fortælles, at det også er sjovt at udfordre sig selv lidt. Eleverne siger altså, at selvom det at prøve sig selv i nye situationer, kan være risikofyldt, så er det også sjovt at blive udfordret.

Eleverne taler positivt om opgaver i skoledelen som er åbne - for eksempel med det eneste krav, at de skal lave en aktivitet for børn i alderen 3-4 år.

Eksemplerne ovenfor kan ses som et eksempel på, hvordan elevernes engagement stimuleres, idet eleverne selv er med til at bestemme indhold, og at netop denne form synes at aktivere engagement og give mod på at lade sig udfordre. Et andet aspekt er, at eleven oplever sig værdsat i det at få ideer, hvilket også for eleven understøtter modet til at prøve nye og ukendte situationer. Eleverne taler her om en legende tilgang til læring i deres entreprenørskabsforløb: 'Man mærkede nærmest ikke læringen komme ind'.

Billede 4, Didaktisk markør for udfordrede elever i entreprenørskabsundervisning: At eleverne er aktive og skaber indhold

Et andet tema, som også blev vigtigt at tale om, er betydningen af at være kreativ; kreativ på en særlig måde; fordi man får mulighed for at frembringe sine ideer i en fysisk form (artefakt). Eleverne fortæller, det er nemt nok at få ideer, men det giver noget særligt at få det ud i hænderne. Eleverne fortæller, de har brugt en særlig teknik, i dette tilfælde cirkelskrivning til at få ideer gennem brainstorming, hvor man skriver videre på de andres ideer. Ingen ideer blev skudt ned, hvilket gav åbenhed ift. at turde komme med ideer og være kreativ. Eleverne fortæller, det især blev spændende, da lærerne havde sagt, deres skitse var for ordinær og havde bedt dem om at tænke det mere kreativt

; det bliver af eleverne beskrevet som både provokerende, men også givtigt, fordi det var en god øjenåbner. Denne form var god til at starte en kreativ proces, fordi man derved undgik at lave det man har set og bare tænke lidt mere over det.

Brug af elevideer til at sætte mål for undervisningen, synes at understøtte elevernes faglige engagement. Et særligt aspekt er forholdet mellem drømme, erfaringer og undervisningen. Brainstorm er et eksempel på en måde at udvikle dette forhold. 
"Jeg synes bedst om at komme ud og brainstorme, selv kommer ud med sine ideer og finder ud af hvad man gerne vil lave. Det synes jeg helt sikkert bedst om. Det der med, at det er fastlagt på forhånd, det er godt nok på en eller anden måde, men jeg foretrækker det andet" (Elevinterview EUD Teknisk).

Citatet viser, hvordan brug af brainstorm gør det muligt for eleven at komme ud med det, som opleves som egne ideer, eleven oplever dette som mere motiverende end undervisning, hvor indholdet er fastlagt eksternt for eleven.

Ovenstående eksempler kan generelt ses som endnu et eksempel på, hvad der stimulerer til engagement og deltagelse, idet eleverne selv er medbestemmende/-bestemmende ift. valg af indhold. Og dét lader til at fremme mod på at komme med nye ideer, og på at møde og håndtere udfordringer.

I undervisningssituationer, hvor socialt udfordrede elever får mulighed for at tage udgangspunkt i sig selv i forhold til det faglige, ser ud til at fremme social interaktion og give øget selvtillid:

"Ja, altså alt på min gamle skole gik galt. Jeg kunne ikke arbejde med andre. Jeg kunne ikke arbejde med lærerne. Jeg skulle bare altid være alene, fordi det ikke fungerede, og man fik hurtigt at vide af sin lærer at, man skulle ikke drømme om, at man skulle blive til noget, og det kan jeg jo stadig mærke når jeg er her, for jeg er stadig usikker på, at når jeg siger noget, at det er det rigtige. Men på grund af, at vi laver så meget kreativt arbejde. Vi laver så meget, hvor vi er os selv. Det giver så meget selvtillid, at jeg begynder, at tro på, at det jeg laver, det står jeg inde for, og det er nok de her 3 ugers innovation, der gør, at jeg kan det" (Elevinterview, EUD Social og Sundhed).

Citatet synes at vise, hvordan interaktionen mellem undervisningen og eleven gennem kreativt arbejde fremmer elevens ansvar "... jeg begynder tro på, at det jeg laver, det står jeg inde for".

Interessant er det, at eleven bruger udtrykket "Vi laver så meget, hvor vi er os selv" Det at være sig selv - selvforglemmende - angives som særligt positivt og lærerigt. Det viser, at elevstyrede forløb fremmer ejerskabet gennem brug af personlige ressourcer.

Næste eksempel viser betydningen af elevers emotionelle oplevelse i form af tilfredshed med sig selv, som del af uddannelsessituationen:

Altså det er altid svært, fordi man skal tænke anderledes og man skal lige finde på noget nyt. Og det er selvfølgelig svært, men når man så får en ide, og især hvis det er en ide, der kommer hele vejen, så får man jo en indre glæde, og man bliver meget tilfreds med sig selv. Eleven fortæller videre, at den indre glæde "giver jo én lyst, man bliver mere motiveret til at gå i skole, fordi hvis man ved, nu har jeg gjort det godt dagen inden, så vil man i skole igen og bevise at det kan jeg også 2 dage i træk. "

(Elevinterview, teknisk EUD)

Ovenstående eksempler ser ud til at vise, hvordan didaktisk brug af elevernes egne ideer fremmer elevernes engagement og optagethed af opgaven. 
I et interview med to piger, der er ordblinde fra EUD Merkantil, siges der om undervisningen:

"Jeg tror også man lærer mere, end når man bare sidder og lytter på en præsentation, for lige pludselig kan du godt sidde og tænke på noget andet, og så er du ikke med alligevel. Men her er du ligesom hele tiden med og du sidder hele tiden og laver noget. I stedet for, at du bare skal sidde og lytte for så er der mange, der godt kan komme til at få tankerne hen på noget andet, og det er ikke på samme måde, når vi sidder og skriver post-its" (Elevinterview, EUD Merkantil).

Eleven i interviewet skelner mellem undervisning, hvor man som elev "hele tiden er med" og "laver noget" og undervisning, hvor man "skal sidde og lytte". Sidstnævnte mener hun "kan komme til at få tankerne hen på noget andet". Aktivering af elevers egne forestillinger og inddragelse af elever som producenter af den viden, som repræsenteres i undervisningen, skaber for denne elev fokus.

Samlet set ser det ud til, at aktiv deltagelse og arbejdet med opbrud af indhold, hvor eleverne i højere grad er medbestemmende på, hvad de skal lave, er fremmende for engagement og deltagelse. Dette omhandler de mulighedsskabende og eksperimenterende aspekter ved entreprenørskabs-undervisning. Åbne veje til forskellige resultater og mål synes altså at fremme elevernes engagement og deltagelse.

Billede 5, Didaktisk markør for udfordrede elever i entreprenørskabsundervisning: At bruge praksisudvikling som nøgle til organisering af undervisningsforløb

På en erhvervsskole, beskriver to elever fra en social og sundhedsskole i et interview undervisningen som varieret; både gennem brug af computer, udføre praktisk arbejde og bruge sine hænder. Det taler eleverne meget positivt om. De to elever beskriver sig selv som udfordret af generthed, meget stille/passive i undervisning og har ikke opfattelsen af dem selv som faglig stærke. Dette selvbillede er fra deres folkeskoletid.

De to elever beretter om et forløb omhandlende entreprenørskab på 3 uger, hvor de har arbejdet 'halv frit'. Med den 'halv fri' opgave menes, at man kunne vælge mellem 5 områder. "Man vælger selv [sit område. red.], og det er det jeg synes, der er det fede ved det her". Det fortæller de, giver frihed til at skabe sin egen ide. Eleverne fortæller videre, at de godt kan lide undervisningsdage, hvor hele dagen er fyldt med ét tema, som i deres entreprenørskabsforløb. Her fremhæves, at KREA er godt fordi, man får lov til at udrette noget. Eleverne fremhæver, at det er godt "at have det $i$ hænderne, udforme det ... og prøve det. Det gør det lettere at huske, og lettere at få noget ud af undervisningen [ved at være med til at vurdere en given aktivitet], når man selv har været med til at lave/prøve aktiviteten" (elevinterview EUD Social og sundhed).

En elev, en dreng fortæller om måden de arbejder på i klassen, at "der er meget selvstændigt arbejde og der er ikke en normal skoleform som man kender [fra tidligere]". Han fortæller, at han altid har været en outsider i sine tidligere skoler, og at lærerne ikke har troet på, at han kunne noget. Han har heller ikke haft mange venner i klassen. "Nu skal selv arbejde 
i klassen, og man skal selv finde på ideer, producerer denne her ting, og det giver så meget til en selv, og det giver en indre glæde. Især i slutningen af ugen. Man blev glad. Altså $i$ løbet af ugen blev man presset, fordi der var pres på for at nå det, så der sidst på ugen, der løsnede vi jo op, for nu var vi jo færdige og nu skulle vi jo bare vise vores spil frem, og vise hvad vi havde lavet. Og så endte vi med at stå stolt oppe med vores produkt, som vi var meget tilfreds med". (elevinterview EUD Social og sundhed)

Ovenstående eksempler kan ses som et brud med meget fagopdelt undervisning, idet der sker en opbrydning af grænser mellem forskellige aktiviteter/fag, og eleverne arbejder selv både med at få ideer til indhold, og løse selvstillede opgaver.

En elev spørges til tidligere skoleerfaringer og svarer: " Jeg har været rigtig meget skoletræt [inden eleven startede på erhvervsuddannelse, red]. Det her er ikke skole". Eleven spørges videre ind til, om han forventer, at han vil klare sig bedre til eksamen: Ja, jeg er bedre i erhvervsøkonomi end jeg har været $i$ andre fag. For det har vi bare skullet kunne, fordi det skulle bruges til en virkelig forretningsplan" (elevinterview, Merkantil EUD)

Der er en række udsagn i interviewene, der fortæller noget om skolens virke med omverdenen og hvor eleverne har opgaver, der peger ud i omverdenen og derved fremmer det at arbejde med autentiske opgaver i autentiske situationer. Disse aktiviteter synes at engagere eleverne. Aktiviteter, hvor undervisningen er i samspil med omverdenen kan betegnes som åbne opgaver, hvor spørgsmål ikke besvares med et svar, men hvor eleven kan vælge mange veje, til at finde løsninger på et autentisk problem som de selv har erfaret. Samlet set ser det ud til, at arbejdet med mere sammenhængende forløb er fremmende for elevernes engagement og deltagelse. De didaktiske greb med praksisudvikling, som omdrejningspunkt omhandler også alle tidligere nævnte aspekter ved entreprenørskabsundervisning. Åben organisering af undervisning med få færdigpakkede forløb synes altså at fremme elevernes engagement og deltagelse.

Billede 6, Didaktisk markør for udfordrede elever i entreprenørskabsundervisning: At læreren ser sig som ressource til at skabe læring

Det, der hjæ/per, fortæller en elev er, at lærerne vil hjælpe, og det er ligetil at bede om hjælp - for eksempel efter faglige oplæg, hvor teorien er blevet gennemgået grundigt, og eleverne har fået lov til at stille spørgsmål undervejs: "Og så gider de lige give nogle gode råd, og er der noget man ikke forstår i teksterne, så kommer de lige ned og forklarer". Eleven taler videre om, at andre elever måske siger, det er at nurse for meget. Det mener eleven her ikke, han taler om en forkert 'nursen', som er når lærerne ikke bryder ind, og stopper op ved for eksempel 'fis og ballade' eller ved 'ikke faglig' brug af mobiltelefoner og computere i timerne.

Eleven skelner i ovenstående eksempel mellem mere eller mindre deltagende elever, og gør opmærksom på, ved at inddrage en erfaring, at ofte 'nurser' lærerne de forkerte elever, nemlig de ikke deltagende og ikke som i eksemplet fra undervisningseksperimentet, hvor læreren har skabt et aktivt deltagende læringsmiljø, hvor det handler om at være faglig engageret i undervisningen og 'høre efter, når det er' og læreren kan give respons 'just on time' 
Ovenstående eksempel er karakteriseret ved at være først lærerstyret gennem fagligt oplæg, og siden åbner op for elevindflydelse ved, at eleverne kan være i dialog med lærerne og bede om hjælp. Eleven gør opmærksom på, at der er behov for at lærere generelt designer deres undervisning med en stærk rammesætning af undervisningen, og holder fokus på den adfærd hos eleverne, som skaber læring og giver den opmærksomhed og anerkendelse.

Det ser ud til at situationer, hvor eleverne har mulighed for, at bruge læreren som ressource til at skabe læring f.eks. ift. hjælp ved egne udtrykte læringsbehov, er fremmende for engagement og deltagelse. Dette skaber muligheder for eleverne, til at fastholde en mulighedsorienteret og eksperimenterende tilgang i undervisningen. Eleverne efterspørger generelt styring ift. positivt faglige læringsmiljøer, hvor læreren er en læringsressource. Det forhold, at eleverne har mulighed for at præge læringsmiljøet mere åbent gennem dialog og spørgsmål til stoffet, synes at fremme elevernes engagement og deltagelse, når det handler om hjælp til egen eller gruppens læring. Mens læringsmiljøet godt må kontrolleres ved, at læreren holder fokus på opgaven, tager styringen og sikre, at alle har fokus på proces og indhold og ikke alt muligt andet.

\section{Billede 7, Didaktisk markør for udfordrede elever i entreprenørskabsundervisning:} At give eleverne en oplevelse af mestring

En murerelev fortæller, at han på trods af negative erfaringer i folkeskolen, hvor han fik at vide, at han ikke blev til noget, ikke har problemer med undervisningen omhandlende entreprenørskab på mureruddannelsen. Ved at opdage og få mulighed for at dyrke sin interesse for flisearbejde inden for murerfaget udvikler han en tro på, at han har noget særligt at byde på. Eksemplet viser, at elevernes selvværd og engagement øges, når eleverne lærer inden for et interesseområde. Han har normalt ikke selvtillid i forbindelse med mere traditionelle undervisning, men siger i interviewet, at han gennem blandt andet undervisning $\mathrm{i}$ entreprenørskab har fået øjnene op for sit talent. Det udtrykker han således: "Jeg kan lidt noget andet end andre de kan" (Elevinterview, Mureruddannelse).

Denne elev fortæller i et interview, at han også fik troen på, at han kunne noget, ved at komme ud og tjene penge. Han oplever nu, at han i forhold til kammerater, der ikke er kommet så langt i deres uddannelse, kan være stolt af at være nået så langt (er "blevet til noget"). Kammeraten, som er med til interviewet, minder ham om, at han hver dag modbeviser det, han fik at vide i folkeskolen:

"[...] ved at sige, at du [...] bliver knaldhamrende god til de fliser, langt bedre end mange andre. Du kan lave noget med dine hænder, og det har det her på skolen jo også været med til at give dig mere selvtillid" (Elevinterview, Mureruddannelse). 


\section{Billede 8, Didaktisk markør for udfordrede elever i entreprenørskabsundervisning:}

At bruge formativ feedback og anerkendelse

'Så har vi en stor gruppe elever med diagnoser som ADHD og Aspergers syndromer og det giver problematikker, hvor eleverne tænker "hvordan kan jeg overhovedet være i et klasserum". Vi har lige haft en elev, som er ved at afslutte nu. Det har været som at se en stor love i et meget lille bur. Det er svært at sige, at han skal være her. Vi har hele tiden lavet individuelle aftaler med ham "hvor kan du være, hvor løser du dine ting, hvornår kommer du tilbage? " for at hjælpe ham ud af det her rum, som for ham er ligesom et fængsel, ellers var han stoppet:

Det er lykkes med ham [at fastholde ham, red.]. Han fik et 12 tal, og vi har vidst det hele tiden, at det her det kan han, han kan bare ikke være i et klasseværelse. Så det er jo nogle problematikker, vi også har. Og så har vi en gruppe elever, som har været udsat for mobning både fra elever og lærer og derfor ikke har kunne række hånden op i skolen overhovedet. De har siddet ni år i folkeskolen med de rigtige svar inde i hovedet, men har aldrig turde lofte armen. Nogle af dem beskriver det som, at de ikke kunne loft armene op. Og det, der næsten er det mest uudholdelige for mig, er dem [elever, red.], der har været udsat for lærer- mobning og udstilling i klasserummet. Det er så forfærdeligt, at det kan foregå, og det er ikke enkelte tilfælde. Der er også sådan en gruppe, hvor det hele handler om, at de er på konstant. Hvor det er de store bevægelser.

Jeg har gjort meget ud af at fortælle eleverne betydningen af, at de trygt kan stille sig op og fortælle noget. Jeg har siddet og snakket med tre af dem, som er ved at afslutte deres uddannelse lige nu. De er et år længere fremme end dem her (klasse som der er blevet observeret i) og de (eleverne) sagde "da jeg startede her ville jeg aldrig have turet at sige noget, bare sidde ned i et klasserum. Og nu gør jeg det bare". (læreren forsætter) Det er jo en kæmpe bevægelse, men jo også en nødvendig bevægelse hvis man skal arbejde i en institution, for der skal man jo kunne sige "hej jeg hedder" til et personalemøde eller forældremøde. (lærerinterview EUD social og sundhed)

En særlig vanskelighed for mange af de udfordrede elever, som vi har interviewet, er nervøsitet ved fremlæggelse. Eleverne fortæller, at der på deres uddannelse er mindre fokus på at præstere og blive bedømt og mere på at fremvise. At fremvise skal forstås som at vise, det man har lavet - hvor også processen frem mod målet anerkendes af lærerne - så selve bedømmelsen/vurderingen får mindre betydning. Eleverne taler i forlængelse heraf, om betydning af at kende hinanden i klassen, det giver tryghed. Anerkendelse får også den positive betydning, at selv om man ikke kan lide at fremlægge, så kan man alligevel godt stille sig op og sige noget, uden at der bliver grint af det. En anerkendende tilgang synes at skabe et trygt miljø, hvor eleverne tør vise produkter for hinanden. Dette kan tolkes som at formativ evaluering, hvor ros og tryghed er i fokus, frem for slutmål og karakterer, er med til, at åbne for elevernes mod til at præsentere.

Samlet set ser det ud til, at en didaktisk praksis, hvor eleverne har medindflydelse på tid, slutproduktet og evalueringsform fremmer engagement og deltagelse. Dette ser ud til at understøtte, at eleverne tør agere mulighedsorienteret, eksperimenterende og innovativt og tør gøre det gennem samskabende processer. 


\section{Afrunding på tredje blik}

Samlet set peger den empiriske analyse tredje blik på, at åbne, ligeværdige og tillidsfulde relationer til lærere og elever, er med til at nedbryde traditionelle mere formelle roller i skolen. Og at åbne opgaver uden lukkede mål, samt organisering gennem samskabelse og handling, giver udfordrede elever nye oplevelser af deltagelse i undervisning og uddannelse på nye måder. Eleverne giver udtryk for, at ligeværdig kommunikation mellem alle involverede og mulighed for indflydelse på tid og mål og evaluering, ser ud til at fremme elevernes engagement og deltagelse i undervisningen.

De didaktiske greb, som udfordrede elever selv fremhæver som engagerende og fremmende for deltagelse kan karakteriseres ved:

- Åbenhed om indhold og form i undervisning - forstået som mere indflydelse til eleverne ift. bestemmelse af, hvad der præcist sker i undervisningen. Dvs. mindre kontrol fra læreren ift. hvordan undervisningen gennemføres.

- Lærerrollen, som bevidst trækker sig i baggrunden for at give plads til elevens selvigangsatte aktiviteter, eller som bevidst er i øjenhøjde med eleverne, og forholder sig undrende, undersøgende og som medskaber i processen for at give lærerstøtte undervejs.

- Elevrolle, som selvstændig og som vil tage ansvar og som en elev, der aktivt vil og kan tage del i egen læring og som stræber efter at 'blive til noget' - og gerne blive til noget særligt' yderligere stræben efter at indgå positivt og konstruktivt i læreprocesser - såvel alene som sociale sammenhænge.

- Gruppearbejde, der arbejder efter kollaborative principper, hvor eleverne har fælles ansvar og træffe de vigtigste beslutninger sammen og alle trækker på samme hammel - trods individuelle forskelle.

- Inklusion gennem samarbejder, hvor eleverne oplever anerkendelse og aktiv deltagelse af alle. Dermed er samarbejdet med til at minimere sociale og faglige udfordringer.

Såvel de elementer, som eleverne selv taler frem som positive og understøttende for engagement og deltagelse, synes samtidig at være de bærende elementer for, at entreprenørskabsundervisning kan være mulighedsfremmende, eksperimenterende og innovativ gennem samskabende processer. Entreprenørskabsundervisning ser ud til at understøtte udfordrede elevers deltagelse og engagement - og mere til. Denne form for undervisning fremmer mod på at møde udfordringer. Faktisk ligefrem på en sådan måde, at eleverne efterspørger udfordringer. Det kan umiddelbart synes modsætningsfyldt, at udfordrede elever engageres i netop at møde udfordringer. Vi så tidligere - ved udfoldelse af forståelse af udfordrede elever v. Videnopsamling fra Marselisborg Praksisvidencenter (2011) samt Pless et al (2015) - at frafaldsproblematikken og frafaldstruede elever anbefales en undervisning, der er karakteriseret ved høj grad af rammesætning og styring gennem - et overskueligt læringsmiljø med klare og tydelige rammer for arbejdet, og tydelige evalueringskriterier. Altså i modsætning til elevernes udsagn i denne analyse, hvor der nok er styring, men på en anderledes måde gennem etablering af undervisningsmiljøer, hvor synlighed i arbejdsprocesser, relationer med mere er rammen for fællesskaber og proces - og relationsstyring er lærerens opgave. Det ses blandt andet gennem arbejdet med at facilitere processer, der understøtter progression i undervisningsforløb og i elevens læring gennem involverende relationelt arbejde.

Sammenfattende kan siges, at de tegn for positiv motivation og læring, der kan registreres i det empiriske materiale med særlig fokus på udfordrede elever er:

Bevægelser fra usikker til mere sikker.

Inklusion i grupper i forbindelse med samarbejde/samskabelse.

Succeser giver selvtillid og lyst til mere. 
Lærere, der opmuntrer og ikke dømmer.

Inddragelse af elevens erfaringer, som afsæt for idéudvikling med mere.

At stemningen i forbindelse med entreprenørskabsundervisning er åben, munter og fri.

Den indsamlede empiri viser betydningen af en didaktik, der tilsigter at fremme entreprenørielle kompetencer hos elever med dårlige skoleerfaringer, både forstået som deres relationer til andre elever og deres forhold til læring. Gennemgående er det som har haft betydning været, at læreren afgiver noget af styringen af undervisningen til eleverne selv, ved at styringen flyttes fra læreren som den der har monopol på viden og svar, til en anderledes styring med fokus på, at læreren i højere grad faciliterer processer, orkestrerer og stiller spørgsmål. Materialet peger på, betydningen af en didaktik, der åbner for læringsfremmende interaktion mellem eleven og elevens omverden.

\section{Fra didaktiske greb til fem didaktiske for- hold af betydning for udvikling af elevernes entreprenørskabskompetencer}

Samlet set viser analyserne fra såvel førsteblik (lærernes ageren i undervisningsrummet), andet blik (elevernes ageren) og tredje blik (udfordrede elever), at der er tegn på, at undervisningseksperimenterne omhandlende entreprenørskab påvirker elevernes motivation, læring og deltagelse i undervisningen positivt.

Igennem de tre blik er det blevet analyseret, hvordan og hvornår elevernes motivation og læring træder frem, og hvilke didaktiske greb fra lærernes side, der særligt synes at fremme motivation og læring. Vi har på den baggrund fremanalyseret fem tværgående didaktiske forhold, ved at kategorisere de didaktiske greb, der særligt synes at fremme motivation og læring. Med didaktiske forhold forstås særlige aspekter, som har betydning for arbejdet med at udvikle elevernes entreprenørielle kompetencer i entreprenørskabsundervisning.

De fem didaktiske forhold er:

- Undervisningsformer, metoder og indhold, der åbner for aktiv deltagelse

- Samarbejde om opgaven og relationer i sammenhæng dertil

- Lærerroller i øjenhøjde, der faciliterer og skubber

- Praksislæring og samspil med omverdenen

- Mestring gennem aktiv handlen og medbestemmelse

I de nedenstående afsnit vil betydningen af de fem didaktiske forhold blive behandlet, med henblik på at få udtrykt betydningsfulde didaktiske forhold for entreprenørskabsundervisning.

\section{Didaktisk forhold som skal være til stede i entreprenørskabsundervisning: Undervisningsformer, metoder og indhold, der åbner for aktiv deltagelse.}

Generelt er undervisningseksperimenterne omhandlende entreprenørskab karakteriseret ved, at det er projektorienterede undervisningsformer, metoder, der tager udgangspunkt i en helhed og lægger op til elevernes aktive deltagelse, og undervisningens indhold er autentisk forstået som, indholdet afspejler virkelige situationer fra erhverv, og dermed kan siges at tage afsæt i omverdenen.

Den projektorganiserede undervisningsform i undervisningseksperimenterne er overvejende organiseret i grupper, hvor eleverne arbejder kollaborativt. Igennem analysen er et karakteristika 
i projektarbejdet, at gruppen eller de enkelte elever selv bliver kilde til viden. I projektarbejdsformen anvender lærerne didaktiske greb såsom udfordringer i form af cases, elevdeltagelse i konkurrencer, og muligheder for at afprøve teorier i praksis for at fremme entreprenørielle kompetencer i forhold til for eksempel omverdensrelation. Flere af lærerne anvender det didaktiske greb, at stille opgaver, hvor praksis skaber en nødvendighed for at lære eller at løse opgaven. For eksempel ses dette i et undervisningseksperiment fra første blik, hvor eleverne fra EUD Merkantil skal deltage i en konkurrence uden for skolepraksis, hvor læring af budgetter bliver en nødvendighed for deltagelse i konkurrencen.

Lærerne bruger et stort antal af forskelligartede didaktiske greb i forhold til metoder i undervisningen, for at fremme entreprenørielle kompetencer hos eleverne. Lærerne anvender det didaktiske greb på tværs af fagretninger, for at få eleverne til at udvikle konkrete produkter støttet af eksperimenterende tilgange, processer og metoder såsom eksperimenthjulet målrettet elever (procesmodel), brainstorm, KIE-modellen (procesmodel), Innovationstrappen (procesmodel), KREA metoden mv., for at fremme udviklingen af entreprenørielle kompetencer. Lærerne anvender didaktiske greb med at stille åbne opgaver, bruge benspænd og udfordringer til udvikling af ideer, at stille spørgsmål for at kvalificere ideer, gå på opdagelse, finde fejl og at give feedback og skub. En elev udtrykker, hvad det at opdage fejl og få idéer kan, sådan her:

"Hvis man har en ide, så kom ud med den. Bedre at få idéen afsted. Når vi kommer ud på arbejdsmarkedet, hvis man ser en fejl, så kan man kommer med en ide til løsning. Det giver en følelse af, at man kan gøre noget bedre, når de erfaren laver en fejl. " (elevinterview EUD Social og Sundhed)

Desuden ses i eksemplerne, at didaktiske greb, der tager udgangspunkt i eleverne, er med til at fremme kompetencer inden for personlig indstilling og handling, hvilket dermed ser ud til at åbne for anderledes deltagelsesmuligheder for eleverne. Lærerne bruger didaktiske greb såsom at tage udgangspunkt i elevfrustrationer, at lade eleverne soge viden selv, lade eleverne lave refleksionsøvelser over samarbejde, at tage elevernes egne spørgsmål op til debat og lade eleverne belyse spørgsmål og problematikker i fællesskab, og at spørge ind til hvad eleverne vil gore ved de problemer de rejser og hvordan de vil gore det.

I forhold til indhold, der fremme entreprenørskab i undervisningseksperimenter kan det siges, at et flertal af lærerne organiserer deres eksperimenter så de indeholder en blanding af teori og praktik, hvor et teorioplæg eller fagligt indspark ofte danner grundlag for elevernes udvikling af ideer og projektstyrede arbejde. Det ses i mange af undervisningseksperimenterne, at eleverne selv får lov til at vælge grupper og emner, hvilket vil blive uddybet i relation til det didaktiske forhold 'Elevstyring og handling'. For at fremme udviklingen af entreprenørielle kompetencer inden for dimensionen personlig indstilling bruger lærerne, i forhold til indhold i undervisningseksperimenterne, didaktiske greb såsom at arbejde med problemstillinger eleverne selv er optaget af, eller har haft en personlig oplevelse omkring, at eleverne får deres ideer ud fra noget, de har set uden for skolens regi, og som de gerne selv vil afprove, f.eks. at eleverne bruger deres praktik som afsæt for at få nye ideer. I forhold til at fremme handling, bruger lærerne didaktiske greb såsom at arbejde med modtagerværdi og "at projekter rettes mod nogen", skaber værdi for andre.

\section{Didaktisk forhold som skal være til stede i entreprenørskabsundervisning: Samarbejde om opgaven og relationer $i$ sammenhæng dertil}

I et flertal af entreprenørskabseksperimenterne arbejder eleverne sammen om at løse udfordringer, og udvikle ideer. 
På anlægsgartneruddannelsen i undervisningseksperimentet fra andet blik tager undervisningen udgangspunkt i modellen innovationstrappen. Eleverne gør rede for anlægstekniske problemer, som de møder i deres hverdag, for derefter at arbejde med et konkret projekt, som relaterer sig til en praksis, de finder relevant. Gartnereleverne fortæller, at de synes godt om at arbejde selvstændigt i grupper, når læreren ikke er til stede, da de så bliver nødt til at hjælpe hinanden. På tværs af eksemplerne, er der ligeledes mange eksempler, der påviser, elevernes deltagelsesmuligheder øges, ved muligheden for samarbejde.

I eksemplet på PAU i eksperimentet 'Den ideelle institution', kommer nogle af de måder hvorpå samarbejde fremmer entreprenørielle handlinger og kompetencer frem. En elev fortæller blandt andet:

" [...] det er jo også godt at være uenige, for så får man diskuteret de forskellige ting, ulemper og fordele ved det. Jeg synes at vi har haft en masse forskellige ideer her, og der har vi jo både set ulemperne og fordelene i det, og så er vi kommet frem til den bedste løsning". En anden elev fra gruppen fortsætter: "[...] Fordi vi er fem og vi skulle lave samme fremlæggelse. Det handlede om kritiske handlinger. Og det kommer ved samtaler og gode eksempler fra vores praktiksteder, det var det bedste hvor vi blev enige til sidst, det var på den måde [...]" (Elevinterview, $P A U)$.

Et andet eksempel fra samme undervisningseksperiment, hvor gruppen bruger erfaringer fra deres praktik til at udvikle nyt, giver et godt indblik i gruppedynamik og fællesskab i samarbejdet om udvikling. Her træder det kollaborative aspekt meget tydeligt frem, og deres relationer i gruppen har betydning for, at en sådan dynamik kan lykkes:

" man tager rigtig meget med fra praktikken, og så bruger vi erfaringer til ligesom at se derfra - okay vi ved, at det her det ikke fungerer, så det skal vi bare ikke. Og så kommer der nogle andre ting, hvor du tænker, det her, det fungerer super godt, og så er der nogle, der kommer og siger, at det også fungerede godt, der hvor de var, men de gjorde på en lidt anderledes måde, skulle vi prove og så tænker man, det lyder meget fedt, og så bliver det lige pludseligt helt nyt"

Det virker som om, at elever får mere ud af at samarbejde og være i fællesskab om en opgave, end hvis de arbejder alene. En elev fra Merkantil EUD siger, at samarbejde har givet hende en indsigt, der går på, at hun nu kan se, at hun tidligere var individualist, men samarbejdet har åbnet for en erkendelse om, at andre i en gruppe, der samarbejder om noget fælles, kan lære hende noget.

En elev fra et fokusgruppeinterview fortæller om sin oplevelse af samarbejde om den fælles opgave sådan her:

Jeg føler, at vi har været gode til at lytte alle sammen, og vi har været gode til at få alle med ind over. Jeg føler, at alle har haft indflydelse på, hvad vi har lavet. Alle har sagt deres mening og jeg synes ikke, at der er nogen, der har været utilfredse med vores endelige produkt. De andre i gruppen nikker samstemmende. (fokusgruppeinterview fra EUD-SOSU - hovedforløb)

I eksemplerne kommer det til udtryk, hvordan samarbejde er et væsentligt forhold i arbejdet med at fremme entreprenørskabsundervisning gennem undervisningseksperimenter, fordi eleverne udfordrer hinandens perspektiver, deler deres viden fra for eksempel praksis, og finder $i$ fællesskab sammen til 'den bedste løsning', som de i nogle af de viste situationer skal præsentere som et samlet produkt. Derigennem bliver gruppearbejdet kollaborativt, hvor lærerens didaktiske greb er at give eleverne et fælles ansvar, at de skal træffe væsentlige beslutninger 
sammen, og at deres produkt og fremstilling og formidling heraf, er indbyrdes afhængig. Denne organisering om opgaven som centrum skaber inklusion mellem elever uanset forudsætninger. Eleverne fortæller, at de oplever sig som deltagere i et inkluderende fællesskab, hvor relationer eleverne i mellem er orienteret om, at bidrage til et fælles tredje [opgaven], med værdiskabelse for øje. Elever, der tidligere har følt sig ekskluderet i skolen og i gruppearbejder, føler sig inkluderet og deltagende i et ligeværdigt læringsfællesskab.

\section{Didaktisk forhold som skal være til stede i entreprenørskabsundervisning: Lærerroller i øjenhøjde, der vejleder, faciliterer og skubber}

Et gennemgående tema i de didaktiske billeder er, at lærernes rolle er forandret fra den traditionelle position som vidensformidler til, at de, ift. undervisningseksperimenterne omhandlende entreprenørskab, i langt højere grad indtager rollen som vejleder og facilitator. Et eksempel herpå, som viser nogle gennemgående karakteristika for lærerrollen, ses i det følgende citat fra eksperimentet 'Opstart af egen virksomhed', hvor en lærer giver indspark og vejledning til eleverne, hvor der er brug for det. Læreren fortæller:

"Så går jeg rundt og hører om der sker noget. Og nogle steder gør der ikke, og så prøver jeg at lave nogle indspark og sige "hvad nu hvis vi forestiller os en butik som lå inde i en anden butik?" - "Nå okay, man kan tænke sådan", og så prøver de. [...] Jeg er meget lidt styrende. Der er nogle lærere, der er noget mere styrende i deres tilgang til det, og det er jeg ikke. Jeg opfatter mig mere som et tilbud. [...] Nej grundlæggende så har jeg mest lyst til, at de sagde ' [lærerens navn], kom lige og hjælp med noget', så når de har behov, så kommer jeg” (Lærerinterview, Handel og kontor).

Ligeledes udtaler en af eleverne: "vi er meget selvstændige, men så hvis vi har brug for hjælp, så er de [lærerne] der meget. Kommer med gode input, og jeg synes, at det fungerer faktisk ret godt med den undervisningsmetode" (Elevinterview, EUD Merkantil).

De didaktiske greb, som lærerne på tværs af undervisningseksperimenterne bruger, handler om at læreren er med på sidelinjen til at støtte og give feedback, at tilføre nye og opfriskende perspektiver, at lytte til elevernes behov, og at give eleverne mulighed for at arbejde konstruktivt med deres usikkerhed. Læreren kan have en faciliterende rolle i forhold til for eksempel, at få eleverne til at reflektere over deres samarbejder og roller i grupperne. Desuden udtaler mange af lærerne, at de i deres anderledes rolle i undervisningseksperimenterne er opmærksomme på, at give eleverne løbende feedback, at sætte rammer, strukturer, og at støtte, skabe overblik og tryghed.

Det ser vi et eksempel på i undervisningseksperimentet fra mureruddannelsen i projektet 'valgfri specialisering', hvor læreren er i stand til at stilladsere den enkeltes læring, ved at følge de individuelle entreprenørskabsprojekter tæt. Det gør han ved at være til stede i lokalet og tilgængelig for eleverne, så han kan hjælpe dem, når de beder om det. Eleverne benytter sig flittigt af den mulighed og nogle giver udtryk for, at det betyder meget for dem, at de altid kan få den hjælp, de har brug for. Med det faglige overblik vurderer læreren, hvilke fagområder, teorier og metoder, der bedst kan hjælpe dem videre med deres selvstændige entreprenørskabsprojekter. Elever på mureruddannelsen giver udtryk for, at de godt kan lide denne lærerrolle, når de kan spørge læreren til råds og trække på hans faglige ekspertise samtidig med, at de selv styrer hvordan de arbejder med deres projekter, hvilket også ser ud til at skabe anderledes måder for deltagelse.

I et andet eksempel fra EUD Social og Sundhed ser vi, hvordan lærerens konstruktive forstyrrelser åbner for af nye deltagelsesmåder: En elev udtrykker det således: 
[...] jamen jeg synes det har været spændende, meget spændende forløb i forhold til de der forstyrrelser vi har været udsat for. Nogle gange har jeg også været sådan "Ej (læreren navn) ikke lige nu, nu vil jeg godt sidde og skrive". Men det har været spændende det der med, at så skulle vi hives ud.

Eksemplerne viser, at lærerens rolle i entreprenørskabsundervisning er, at stille sig ved siden af og forholde sig undrende, undersøgende og medskabende i elevernes læreproces. Lærerrollen i entreprenørskabsundervisning skaber et lærerstøttet læringsrum for eleverne, og vores analyse viser, at det er med til at fremme elevernes motivation og læring.

\section{Didaktisk forhold som skal være til stede i entreprenørskabsundervisning: Praksislæring og samspil med omverdenen}

Praksislæring og inddragelse af omverdenen er et didaktisk forhold, som flere greb peger i retning af, og det er tydeligt i de didaktiske billeder, at et flertal af lærerne på tværs af undervisningseksperimenterne bruger praksis og omverdensrelationer i arbejdet med, at udvikle entreprenørielle kompetencer. Desuden beskriver flere af eleverne den direkte kontakt til praksis og omverdenen, som nyt og motiverende. Inddragelse af andre institutioner eller konkrete oplevelser med målgrupper (skolebørn, hjemløse, kunder, aftagere, etc.) styrker elevernes engagement og forståelse af den verden, deres kompetencer skal omsættes og gøre gavn i. I praksisorienteret- eller omverdens-relateret undervisning situeres elevernes læring i erfaring af og med praksis/omverden. Det er en forskydning fra klasserummet ud i omverdenen, som løfter elevengagementet $\mathrm{i}$ undervisningen.

En lærer fra EUD Merkantil siger:

Konkurrence styrker, og de [eleverne] føler, at de bliver taget alvorligt af eksterne partnere. Vi skal tage dem alvorligt med de forslag som de kommer med. - Tag [elevens navn] som udgangspunkt, han er udfordret på mange punkter, men lige her .... for pokker da, han er en guttermand. (fra fokusgruppe interview med lærer)

I ovenstående citat hører vi dels, hvordan en lærer oplever, at elever vokser og tager ansvar, når eksterne partnere inddrages $i$ undervisningen. Samtidig zoomer citatet ind på, hvor elever med særlige udfordringer profiterer af entreprenørskabsundervisning - her i form af en konkurrence med inddragelse af eksterne partner.

I undervisningseksperimenterne 'Praktikpladssøgning' og 'Matematik' fra EUD Merkantil ses det, hvordan det lykkes at udvide læringsrummet i traditionelle skolastiske fag, så det går ud over klasserummet. Underviseren i matematik har brugt formidling af viden, som ramme for udvidelse af læringsrummet til at omfatte en anden fysisk lokalitet og andre relationer end de, som traditionelt er indeholdt i skolens struktur. Udvidelsen er forankret i en undervisningsopgave. I EUD Social og sundhed ser vi eksempler på, hvordan projektorienteret arbejde kan udvide læringsrummet ved, at eleverne eksempelvis i hovedforløbet på en PAU uddannelse skal udvikle aktiviteter til børn i institutioner på baggrund af oplevelser fra praksis, og senere skal afprøve dem og få feedback fra praksis. Eleverne henvender sig her i tanke og handling til fremtiden og til en verden uden for klassen. Dette situerer elevernes læring i nye relationer, og ser ud til at styrke elevernes personlige indstilling, hvilket påvirker læring positivt.

På tværs af undervisningseksperimenter ses det, hvordan didaktisk etablering af samspil med omverdenen knytter det, der skal læres, til elevernes erfaring og drøm om fremtidig praksis med en fagrelevant kontekst, hvilket skaber anderledes muligheder for deltagelse.

Helt konkret bruger lærerne didaktiske greb, såsom at eleverne skal få feedback og blive taget alvorligt af omverden F.eks. ved at de skal pitche ideer og resultater i praksis, og få feedback af fagprofessionelle. At eleverne skal udvælge og kontakte en repræsentant for målgruppen. At 
eleverne skal på besøg i praksis. At de skal bruge deres eget netværk - didaktisk kontekstualisering. Og at de skal samarbejde med virksomheder om udvikling af konkrete produkter.

Et eksempel på en lærers didaktiske overvejelser om praksisblik og omverden ses i følgende citat fra eksperimentet 'Opstart af egen virksomhed', hvor læreren udtaler at han godt kunne tænke sig at bringe omverden tættere ind i skolen:

"Jeg kunne godt tænke mig at få erhvervslivet til at vurdere dem. Der sker et eller andet, når der kommer folk udefra i forhold til den almindelige læring. [...] Jeg synes ikke det behøver at være konkurrencer, men dét at de stiller sig op overfor fremmede, og skal stå inde for det de har lavet. Men det er svært i en klasse, hvor det er kammeraterne, der sidder der. Så er det svært for dem at lofte sig og sige 'nu tager jeg mig selv alvorligt, og jeg vil præsentere det så godt som muligt'” (Lærerinterview, EUD Merkantil).

\section{Didaktisk forhold som skal være til stede i entreprenørskabsundervisning: Mestring gennem aktiv handlen og medbestemmelse}

På tværs af billederne ser vi eksempler på, at det har betydning for elevernes aktive handlen, at undervisningen giver differentierede muligheder både i forhold til det faglige niveau, og i forhold til måder det er muligt at tilgå undervisningen. Dette kommer for eksempel til udtryk ved, at eleverne har indflydelse på definition af indhold og proces i deres projektarbejde. Analysen peger på, at eleverne kan opleve en følelse af mestring når de har medbestemmelse, kan styre og handle frit i deres entreprenørskabsprojekter.

Et eksempel på dette er murereleverne fra undervisningseksperimentet 'valgfri specialisering', hvor de selv vælger, hvad for en slags murværk de vil arbejde med og hvor de, i deres entreprenørielle projekter, arbejder ud fra egne idéer med projektering og udregning. Eleverne giver udtryk for, at det betyder meget for deres engagement, at de kan arbejde ud fra egne interesser. Det lærer dem bl.a. at søge informationer selv, at opsøge hjælp og at føre deres valg ud i livet (at handle). På denne måde lærer de også at stå ved egne beslutninger.

Der er nok færre begrænsninger, hvis man finder ud af, at man kan mere end man troede man kunne. Og hvis man lærer nogle nye ting. Ting man ikke har prøvet før kan tit blive til ting, jeg ikke kan, du ved "det kan jeg ikke" selvom jeg aldrig har provet det før. Men hvis man altid får lov, også får lov til at prøve noget nyt, og får lov til at tænke selv uden, at der er nogen, der skal tænke for dig. [.....] det er bare dig, der finde ud af, hvordan det her skal være - step by step. Det synes jeg, at jeg lærer meget af. (elev fra SOSU - hovedforløb)

Elevstyring og handling fremmes blandt andet ved, at eleverne skal lære at vurdere egen præstation selv og give feedback til hinanden. På automatikteknikeruddannelsen virker læringsmiljøet, udfordrende for nogle af eleverne når de skal give hinanden feedback. En elev fortæller, at undervisningseksperimentet har udfordret dem: "Måske [har det] taget os lidt ud af vores comfort zone [...]. Men eleverne giver også udtryk for, at de - fordi de går i en klasse, hvor de er gode til at hjælpe hinanden - lærer noget af at kunne trække på hinandens forskellige viden.

En lærer fra en EUD merkantil fortæller om den ændrede elevrolle i entreprenørskabsundervisning:

Det helt anderledes er, at det er eleven, der kommer og sporger mig, det er helt nyt - de føler, at de har behovet. [ovenstående er sagt i en dialog, hvor det er elevens egen idé, der er genstand] 
I ovenstående er det beskrevet, hvordan de didaktiske greb som lærerne anvender i deres undervisningseksperimenter kan kategoriseres i fem didaktiske forhold, som går på tværs af fag og undervisningseksperimenter. Det kan siges, at undervisningsformer, metoder, og indhold, samarbejde, lærerrollen, praksisblik og omverden, og elevstyring og handling, har en særlig betydning i udviklingen af undervisning omhandlende entreprenørskab og, at de fem didaktiske forhold har betydning for elevernes muligheder for læring, og for at deltage engageret og dermed mere motiveret i undervisningen.

\section{Sammenfatning}

\section{Sammenhængen mellem didaktiske greb og forhold \& motivation og læring}

Med afsæt i de empiriske analysers blik 1, 2 \& 3 vil vi her lave en opsamling af, hvordan vi ser, at undervisningseksperimenterne omhandlende entreprenørskab synes at fremme motivation og læring. Og hvad kan der siges om dette, når vi inddrager teori fra forstudiet.

Vores empiriske analyser viser mange eksempler på, hvordan undervisningseksperimenterne udvikler elevernes motivation og læring gennem engagement og aktiv deltagelse. Løbende har vi gennem præsentation og analyse af data vist, hvor det ser ud til, at eleven er i læring og er motiveret.

\section{Didaktiske greb og forhold fra undervisning gennem entreprenørskab, der fremmer motivation}

De empiriske analyser peger på, at mange af de didaktiske greb, som ligger til grund for entreprenørskabsundervisning, skaber gode betingelser for udvikling af motivation. I det følgende trækker vi eksempler frem fra det empiriske materiale i de tre blik som viser, hvordan entreprenørskabsundervisning fremmer motivation gennem anvendelse af en række forskellige didaktiske greb.

\section{Betingelser for motivationsorienteringer}

Som tidligere skrevet skabes betingelser for motivationsorientering i samspillet mellem meningsgivende principper og klasserumskultur (Pless et al. 2015, s. 35), Her påpeger hun, at eleverne orienterer sig $\mathrm{i}$ forhold til såvel det, som giver mening for dem og $\mathrm{i}$ forhold til kulturen $\mathrm{i}$ form af omgangsformer og undervisningsformer, som de deltager i. 'Motivationsorienteringer' handler således om, hvad eleven orienterer sig mod - og er afgørende for, hvad eleven engagerer sig i og deltager i (eller det modsatte). Denne motivationsorientering ses tydeligt af vores empiriske analyse andet blik som en grundforståelse; når eleverne orienterer sig mod det medie som er omdrejningspunkt for deres uddannelsesvalg. For eksempel som vi nævner mennesker i en SOSU-uddannelse eller fysisk materialitet i en teknisk uddannelse, som værende betydningsfuld for deres motivation til at engagere sig i den undervisning gennem entreprenørskab, som lærerne har gennemført i regi af et undervisningseksperiment.

Motivation skabes i mødet mellem det, som giver mening for eleverne, og den brancheskole- og den klasserumskultur, de agerer i forhold til. Som vi beskrev i afsnittet om deltagelsesmåder (andet blik) viser det empiriske materiale eksempler på, hvordan lærernes didaktiske greb medvirkede til, at eleverne fik mulighed for at deltage på bestemte måder i undervisningen. Man kan sige, at elevernes deltagelse, viser noget om, hvorvidt de didaktiske greb har givet dem mulighed for at koble til det, som giver mening for dem således, at de udvikler motivation for læring og for at fortsætte på uddannelsen. 
Ved at se nærmere på forskellige orienteringer for motivation, får vi øje på en række eksempler på, hvordan elever får mulighed for at tackle udfordringer, som de kan opleve har været forhindrende for dem i andre uddannelsesmæssige sammenhænge. Kategorierne for motivation er inspireret af Pless et al. (2015, s. 63), som opfatter motivation som multidimensionel. Analytisk kan det give mening at skille elementerne ad, men forskellige motivationsformer vil ofte spille sammen (Pless et al. 2015, s. 63).

I tråd med tænkningen i Unges motivation i udskoling (Pless et al., 2015) ser vi i analyserne, at motivation udvikles som et resultat af det, der foregår i undervisningen. Motivation er en forudsætning for læring, men den er ikke nødvendigvis givet på forhånd. Det er i forbindelse med elevens deltagelse i undervisningen, at denne drivkraft for læring kan styrkes.

\section{Undervisningsformer og motivation}

De didaktiske greb, som læreren har anvendt i deres undervisningseksperimenter og de didaktiske markører, som vi har brugt til at rammesætte forskellige billeder, svarer overordnet set til de faktorer i entreprenørskabsundervisning fundet i andet forskning om motivation, som Fonden for Entreprenørskab blandt andet har udlagt i Taksonomi i Entreprenørskabsuddannelse (2016, s. 32). Her viser det sig, at undervisning som skaber engagement og motivation gennem entreprenørskab:

1. Fokuserer på varierede samt autentiske og praktisk rettede opgaver, som er meningsfulde, udfordrende og skaber værdi for andre

\section{Tilsvarende viser vores analyse, at eleverne finder mening:}

- Når opgaven har relevans i forhold til fagets udøvelse i praksis, som det sker i på EUD Social og sundhed, hvor eleverne arbejder med misbrug for at blive klogere på, hvordan de kan forstå psykiatriske patienter.

- Når de kan se, at det giver dem kompetencer, som gør det muligt at deltage i et fagligt og arbejdsmæssigt fællesskab i deres fremtidige liv. Det sker for eksempel, når murer-elever fortæller, at de ved at arbejde med eksperimenthjulet målrettet elever, lærer noget om at arbejde struktureret på en måde, som de kan bruge i deres fremtidige arbejde som faglærte.

- Når arbejdet med opgaven giver mulighed for at skabe værdi for andre. Det ser vi $\mathrm{i}$ et eksempel fra EUD Social og Sundhed, hvor eleverne arbejder med at skabe legeaktiviteter for børn. De trækker på deres engagement i faget, som ifølge læreren handler om, at de gerne vil gøre noget for andre mennesker.

2. Udfordrer elevernes kreativitet og problemløsningsevner og give plads til forskellige talenter

Tilsvarende viser vores analyse, at innovationsprocesser og opgaver, som kan løses på forskellige måder åbner for:

- Forskellige og kreative måder at løse problemer og opgaver på. Det sker, for eksempel når EUD Social og Sundhed -elever $\mathrm{i}$ andet blik får til opgave at finde på nye måder, at tænke forhold $\mathrm{i}$ institutioner med afsæt $\mathrm{i}$ de udfordringer som de har mødt $\mathrm{i}$ praktikken.

- At eleverne kan trække på det, de er særlig gode til, som vi ser i eksemplet, hvor murereleverne skal finde ud af selv at konstruere et murværk. Én af eleverne valgte at arbejde med fliser, som han havde særlig flair for, og kunne videreudvikle sine kompetencer i forhold til. 
- Billederne om kreativitet (i førsteblik) viser desuden, at didaktiske greb som at arbejde med eksperimenterende aktiviteter, at stille åbne og umulige opgaver samt at invitere til refleksion i forhold til fantasi og refleksion medvirker til, at eleverne 'skubbes' videre ved at få åbnet for deres fantasi således, at de kan arbejde mere kreativt med deres idéer.

\section{Omfatter gruppearbejde}

Tilsvarende viser vores analyse at samarbejde i grupper med fokus på kollaboration betyder:

- At eleverne skal arbejder sammen om opgaven. At de er afhængige af hinanden bidrag til løsning. At de får mulighed for at deltage i et læringsfællesskab, hvor de kan dele erfaringer og viden. Mange elever giver udtryk for, at samarbejdet betyder noget for dem, både fordi de får mulighed for at trække på hinandens viden og hjælpe hinanden og de udvikler samarbejdskompetencer, som de får brug for i deres fremtidige fagudøvelse

\section{Giver eleverne ejerskab og ansvar for opgaver og læreproces}

Tilsvarende viser vores analyse, at elevene vægter medbestemmelse og indflydelse:

- Mange elever i analysen giver udtryk for, at det virker meget positivt, når de får mulighed for selv at bestemme, hvad de vil arbejde med og hvordan, for eksempel at arbejde selvstændigt. Eleverne har positive oplevelser når de selv skal styre deres læring, ved for eksempel at få mulighed for at tage udgangspunkt i deres interesser, talenter og at opøve kompetencer, som de får behov for i deres fremtidige jobs.

- I billederne på handlingsdimensionen (første blik) ser vi desuden, hvordan lærerens tro på, at eleverne selv er i stand til at sætte retning, stille spørgsmål, søge svar og i det hele taget være eksperimenterende og undersøgende, ser ud til at give eleverne lyst til at tage ansvar for aktiviteter, og tro på, at de er i stand til selv at foretage faglige vurderinger og valg.

Giver eleverne mulighed for at udføre alle aktiviteter fra idé til resultat

Vores analyse peger på at brugen af innovations- og entreprenørskabsmodeller støtter proces fra idé til resultat.

- Flere af de didaktiske billeder belyser situationer, hvor lærerne har tilrettelagt undervisningen ud fra innovations- og entreprenørskabsmodeller, der rammesætter et læringsforløb fra idé til resultat, og at denne rammesætning i undervisningen er med til at give eleverne en oplevelse af fokus, mulighed for fordybelse og tid til at komme hele vejen rundt omkring opgaven. Det ser vi: I eksemplet fra mureruddannelsen andet blik, hvor elevernes engagement og lyst til faglig fordybelse hænger sammen med, at de med udgangspunkt i eksperimenthjulet målrettet elever, arbejder med alle faserne i deres projekter, som ender med at blive udført i praksis.

- Ligeledes har det betydning for EUD Social og Sundhed-eleverne, at deres projekter med at skabe legeaktiviteter, skal føres helt frem til, at de afprøver de nye aktiviteter med børn i daginstitutioner.

\section{Arbejder med ting der interesserer dem, helst ting de er emotionelt optagede af}

Vores analyser peger på, at undervisningen kan bygge på et didaktisk greb, som har en dobbelt funktion: 
- Når undervisningen tager afsæt i elevens interesser, passion og erfaringsverdener, er der gode chancer for, at eleverne kan identificere sig med indholdet, som derved giver mening, er motiverende og engagerer eleven. Det er et gennemgående træk i mange af de didaktiske billeder, f.eks. i situationen med udvikling af et terrarium til krybdyr i billede 1 under personlig indstilling, hvor eleven arbejder med sin passion for krybdyr til at udvikle nyt. Derudover ser vi også, at det erhvervsfaglige og erhvervsrettede i de tre overordnede typer af erhvervsuddannelser, vækker meget interessebetonet engagement og motivation hos eleverne, som vi så da en elev fra EUD Social og Sundhed gav udtryk for, at det var arbejdet med mennesker, som havde været hendes drøm altid. Dette og lignede eksempler tydeliggør, at erhvervsuddannelserne kan skabe en unik mulighed, for gennem kernefagligheden, at arbejde med entreprenørskab.

- Når undervisningen knytter an til noget, som eleven er emotionelt optaget af, er der gode muligheder for at åbne for forbindelser mellem kognitive og emotionelle dimensioner i læring. Det ser vi f.eks. i billedet hvor en elev med faglige og personlige udfordringer fortæller, hvor emotionelt engageret han blev i problematikker om hjemløse, fordi han i praksis så hvilken glæde og forskel det gjorde, at hjælpe.

7. Gør det tydeligt hvordan resultaterne skal bruges, og hvilken værdi dette skaber

Tilsvarende viser vores analyse, at elevene vægter undervisningen med praktisk relevans og værdiskabelse for andre:

Der er adskillige eksempler i billederne på, at det har betydning for eleverne at kunne se, at arbejdet med undervisningsaktiviteterne fører frem til resultater med relevans i den praktiske verden, herunder resultater, som skaber værdi for andre.

- Det ser vi for eksempel i billedet (andet blik) fra EUD Merkantil, hvor HG-elever underviser yngre elever i matematik. Deres motivation ser ud til at blive styrket ved, at de har en funktion i at gøre noget nyttigt i forhold til andre, hvis behov de kan identificere sig med.

- I billederne på handlingsdimensionen (første blik) ser vi, hvordan didaktisk etablering af samspil mellem elevens motivation og fremtidige arbejdssituation, ser ud til at påvirke læring positivt. På EUD Merkantil har elevdeltagelse i konkurrencer sikret interaktion med omverdenen. Her tilkendegiver nogle elever klart, at konkurrenceelementet har givet dem større lyst og motivation til uddannelse.

- Nødvendighed ser ud til at fremme motivation og eksemplet viser, hvordan bevidst interaktion med omverden har betydning for elevernes læring. Eleverne motiveres af konkrete relationer og motiveres til at lære i en forståelse, der emergerer som del af interaktionen mellem elev og omverden.

\section{Didaktiske greb og forhold fra undervisning gennem entreprenørskab, der fremmer læring}

Ift. den læringstilgang som vi i indledningsvist har beskrevet som afsæt for undervisning gennem entreprenør, nemlig sociokulturelle læringssyn, så kan vi også her sige, at når undervisningen intenderer at hvile herpå, så ser det ud som om, at elevens læring styrkes.

Vi opsummerer først de centrale elementer i den sociokulturelle læringsforståelse, om at læring:

- Er situeret, grundlæggende social, distribueret og medieret,

- Omhandler deltagelse i praksisfællesskaber. 
- Erfares gennem handling og sker gennem en eksperimenterende tilgang.

\section{Læring gennem entreprenørskab er situeret, grundlæggende social, distribueret og medi- eret}

I flere af de nævnte eksempler på elevernes læring, er målet for handlingen ikke læringsmålet i sig selv. Handlinger er led i overordnede mål om at imødekomme uddannelsens læringsmål. F.eks. når eleven arbejder med at udarbejde budgetter til en konkurrence, så imødekommer aktiviteten derved et uddannelsesmål vedr. forretningsplanlægning. Men læringen sker ikke i en traditionel skolastisk form løsrevet fra praksis - men netop i tilknytning til en opgaveløsning relateret til autentiske opgaver. Det understreger det situerede, distribuerede og medierede aspekt i læreprocessen. Og analysen viser, at netop denne læringstilgang i særlig grad ikke kun understøtter læreprocessen, men også bidrager til at udholde og fastholde en optagethed af, at forbedre sin kunnen. Det synes også som om netop disse arbejdsformer understøtter elevens motivation. Man kan sige, at motivation og læring gensidigt forstærker hinanden.

Deltagelsesaspektet i den læringsforståelse, der er skrevet frem i indledningen, handler således om at læring ikke blot understøttes gennem deltagelse, men det er også en central del af selvlæringen. Gennem deltagelse lærer man om, hvordan en given opgave skal løses. Det er her ret interessant, at eleverne gennemgående synes at vise en særlig optagethed af at fortælle om måder, hvorpå de deltager i aktiviteterne, og at netop disse deltagelsesmåder synes at være såvel motiverende som læringsfremmende. Eleverne viser i deres udsagn om læreprocesserne, at de er dybt optagede af at deltage i de igangværende processer - idet de tydeligt kan identificere forhold, der kendetegner denne deltagelse (herunder hvad der hæmmer og fremmer for deltagelse). Følgende eksempler kan illustrere dette:

Netop det, at eleven både forventes og anerkendes i at træffe egne valg, synes at udvide elevens deltagelsesmuligheder i retning af, at tage ansvar for læreprocessen og selv styre, hvornår læreren skal inddrages:

"Jeg vil gerne have hjælp, for jeg er lidt i tvivl om det her'. ......'Det er mig, der står for det, det er mig, der vælger hvad for noget materiale jeg vil have, det er mig, der vælger, hvordan det skal se ud', og så kan vi spørge dem til råds, for vi er stadig lidt uerfarne i det, så jeg synes, vi får meget ud af det (Citat fra Elevinterview).

Et andet lignende eksempel viser en murerelev, der spørger læreren: "Er det nødvendigt at lave projekteringen med tegneprogrammet?'. Til det svarer læreren: "Nej, du kan også tegne i hånden". Dette understreger ikke blot lærerens fleksibilitet ift. metoder for f.eks. projektering; men det viser også, at eleven kan positionere sig, som en der kan stille - kritiske - spørgsmål til undervisningen og bidrage med forslag. Altså det viser en deltagelsesmulighed, hvor eleven kan være mulighedsorienteret og indgå i en ligeværdig forhandling med læreren om didaktiske overvejelser. Også denne deltagelsesmulighed synes at forstærke såvel motivation og læring.

\section{Læring gennem entreprenørskab fremmer samarbejde som deltagelse i et praksisfælles- skab}

Et eksempel herpå er, at eleverne synes særligt optagede af at lykkes med at samarbejde med andre elever. Den kompetence som eleven er optaget af her, kan være samarbejde - en optagethed, som eleven/eleverne ikke nødvendigvis er bevidste om, men det er tydeligt at eleverne engagerer et stort bevidsthedsarbejde heri. Et citat fra afsnittet om elever, der er udfordrede kan illustrere dette: Det er jo tit, hvis man skal være sammen med én, der ikke er så faglig stærk, så kommer de med en skide god idé og så propper jeg bare nogle store ord på, og så fungerer det ligesom bare. Eleven synes optaget af at løse en opgave med at udfolde en ide teoretisk.

Denne proces ser samtidig ud til at understøtte læring i sociale kompetencer, videre ser det ud 
til, at eleven motiveres gennem handlingen. Udsagnene 'kommer de med en skide god idé ... propper jeg bare nogle store ord på' synes at indikere personlig involvering i form af engagement. Et andet eksempel fra dimensionen Handling (billede 3) illustrerer også den personlige involvering og bevidsthedsarbejdet med at lykkes med samarbejde: En elev fortæller om gruppearbejdet, at hun er blevet 'lidt mere forsigtig med at skyde andres ideer ned og at det faktisk er nemmere end man tænker over. At man gor det [skyder ned] uden at tænke over det. Eleven investerer megen energi i denne nye opmærksomhed (at undgå at skyde andres ideer ned, kræver, at man tænker over det) og det synes som personligt vigtigt for hende at fastholde denne opmærksomhed.

Samme pointer kan trækkes frem ift. temaet 'deltagelse i fællesskaber'. Elevaktionen, hvor elever hjælper hjemløse fortæller, at netop fællesskabet i gruppen har understøttet og initieret elevens deltagelse og engagement og, at han har følt sig inkluderet i et fagligt fællesskab som han har tidligere, i grundskolen, har følt sig ekskluderet fra og som han mener skyldes hans faglige og personlige udfordringer. Således ser det ud til, at fællesskabet både kan initiere læring (gennem det, at aktiviteten betyder noget - det er seriøst) og både kan være hjælp til fastholdelse af læreprocessen (vi blev alle påvirkede og vi holder alle sammen). Læring er i denne sammenhæng afhængig af social inklusion. De to eksempler viser, at det kollaborative element om opgaven som er et must, når vi taler om entreprenørskab gør, at eleverne bliver inkluderet i et socialt fællesskab og de får adgang til både en social og kognitiv læreproces. Vi ser i de didaktiske billeder, at eleverne har skiftende placeringer i fællesskabet om den opgave, der skal udvikles, og at placeringerne ikke, som det måske er normal praksis er, at elever med faglige og personlige problemer placerer sig i periferien af deres fællesskab, men i stedet indtager en ligeværdig placering med samarbejde om opgaven for øje.

I eksemplet, hvor en elev fortæller om betydning af at hjælpe hinanden, fremgår det også tydeligt, hvordan eleven oplever det hæmmende, hvis blot læreren docerer viden.

"Og det er bare svært at vide det hele, så det gælder også om at være god til at hjælpe hinanden på kryds og tværs, for at man kan tage lidt. Og det har man jo muligheden for, når man kører det lidt mere selvstændigt og opsøger information kontra at der bare er en, der står og siger det hele" (Citat fra Elevinterview).

Også ovenstående eksempel viser, at en deltagelsesform, hvor eleverne bruger hinanden til råd og vejledning, fremfor blot at bruge læreren, synes at fremme motivation og læring. Samtidig er der også tale om en deltagelsesform, der positionerer eleven som medansvarlig og hvor selve deltagelsen (at anerkendes i gruppen) også synes at fremme motivation og læring.

\section{Læring gennem entreprenørskab erfares gennem handling og sker gennem en eksperi- menterende tilgang.}

Vores analyse peger på at læring erfares gennem handling og sker gennem en eksperimenterende tilgang. Dette ses b.la. i eksemplet med eleven, der arbejder med udvikling af et krybdyrterrarium. En interesse om at undgå, at dyrene døde, var incitament for at handle og eksperimentere. Og at netop dette incitament synes at tilskynde og intensivere elevens læring. Incitamentet kan samtidig tolkes som elevens motivation for læreprocessen. Også her ses, at motivationen beriges og forøges gennem elevens mulighed for at handle og eksperimentere.

Undervisningseksperimenterne har åbnet for nye læringsrelationer. Og i forlængelse heraf også for nye erkendemåder. Den måde Fonden for entreprenørskabs fire dimensioner inddrages $i$ elevopgaver eller elevaktiviteter, synes at udvide læringsindholdet. Med det menes, at eleverne ikke bare lærer mere eller er mere motiverede, men at de lærer anderledes og herigennem ser ud til at have et ændret læringsudbytte. Dette kan illustreres ved eksemplet fra dimensionen 
omverdensrelation (billede 1), hvor en elev ikke kun lærer at lave budgetter, men også lærer noget om at udholde læringssituationer, der kræver hårdt arbejde, selv om eleven ikke tidligere har opfattet sig selv, som god til tal eller at tal havde elevens opmærksomhed og interesse - det Hermansen vil kalde læring med møje (Hermansen, 2005/2012).

Et andet eksempel fra samme dimension, hvor elever på en landbrugsskole arbejder med en uvant målgruppe - børn og unge. At målgruppen er uvant nødvendiggør måske, at eleverne selvstændigt må finde nye og kreative måder at møde målgruppen på. Gennem processen lærer eleverne ud over viden om målgruppen også at håndtere nye og uvante situationer.

Som vi har set i de didaktiske billeder, er lærerens stilladsering af den enkeltes læreproces en vigtig faktor $i$, at eleverne oplever en slags vished. Når de føler sig trygge og ved, at de kan få den støtte, som de har behov for, og at sparring er i øjenhøjde med afsæt i opgaven, der skal løses, så får eleverne mod til at knokle sig igennem og lære de faglige teorier, metoder og færdigheder, som ellers for nogle af de udfordrede elever så ud til at være uoverstigelige. Motivationen til at overvinde de faglige udfordringer, er en nødvendighed for flere af eleverne med udfordringer, for at de kan komme videre med at arbejde i deres proces gennem handlen og eksperimenteren.

Et andet eksempel ser vi i billedet fra en HG-klasse (andet blik) i forbindelse med et forløb, hvor elever bl.a. har formuleret interviewspørgsmål. De giver her udtryk for, at motivationen til at handle og prøve sig frem kommer af, at de føler de kan magte opgaven fordi de har fået lejlighed til at øve sig på delelementer undervejs. I kraft af elevens øgede engagement og iver for at lykkes med den givne opgave, understøtter det elevens læring.

\section{Afrunding}

Vi har med afsæt i den empiriske analyse første, andet og tredje blik vist, hvorledes motivationsorienteringer (Pless et al. 2015) forstået som det, som eleverne orienterer sig mod f.eks. medierne for de tre erhvervsuddannelser mennesker, fysisk materialitet og symboler, er afgørende for, hvad eleverne engagerer sig og deltager i. Der hvor de didaktiske greb, som læreren har brugt i sin undervisning, til at fremme elevens entreprenørielle kompetencer, har understøttet motivation og dermed læring, har vi diskuteret sammenhængen i ramme af syv faktorer i undervisningen, som Fonden for Entreprenørskab $(2016$, s. 32) mener har betydning for elevernes motivation.

I sammenfatningen har vi set på sammenhængen mellem undervisningen gennem entreprenørskab og hvad den betyder for elevens læring med det formål, at udvikle entreprenørielle kompetencer. Det er tydeligt, at undervisningsformer, hvor læreren giver plads til elevernes idéer, faglige indspark, planlægning af tid og forløb og selv træder enten i baggrunden eller gennem sparring, er i øjenhøjde med eleven. Hvor eleven får mulighed for at deltage i og bruge ressourcer i praksisfællesskabet (de andre elever på holdet) ikke blot fremmer læring, men også udvider og forstærker læring. Endvidere viser analysen, hvorledes undervisningseksperimenterne omhandlende entreprenørskab i deres didaktiske opbygning og valg af anden lærerrolle, eller ligefrem lærerposition, synes at gøre motivation og læring gensidigt forstærkende. Et andet gennemgående træk er, at såvel arbejdet med dimensionerne (kompetencer for entreprenørskab) samt ændrede deltagelsesmåder i retning af, at eleven får muligheder for at være medskaber og selv designe indhold til entreprenørielle forløb fra udfordring til produkt, og tage medansvar for læreprocesser, synes at fremme motivation og læring.

Vores analyse peger på, at det har stor betydning for eleverne og i særdeleshed elever med udfordringer, at de tror på, at de kan magte de opgaver, de arbejder med i undervisningen. Det er vigtigt for deres engagement, at de tror på, at de kan komme til at mestre opgaverne, og at de 
ikke oplever sig bremset af frygt for, at deres evner ikke slår til. Når de oplever succes med en opgave, giver det dem blod på tanden i forhold til at kaste sig ud i den næste opgave.

Et gennemgående træk i vores analyse er, at elevernes engagement ofte viser sig i forbindelse med deres muligheder, for at arbejde aktivt med undervisningsaktiviteterne. Deres selvvirksomhed og foretagsomhed ser ud til at hænge sammen med, at de får mulighed for at arbejde med opgaver, som giver mening for dem og som de selv har været medbestemmende omkring.

Samlet set er der således adskillige eksempler på, at den gennemførte undervisning initierer motivation og læring. Det er særligt bemærkelsesværdigt, at det er et gennemgående træk, at når eleverne får mulighed for at arbejde med læring ift. noget, der er personligt meningsfuldt, involverer handling, samarbejde med andre elever, kreativitet og autentiske opgaver, der værdsættes i omverdenen, så øges deres intensitet og engagement.

\section{Afslutning}

\section{Fra undervisningseksperimenter til entreprenørskabs- undervisning}

Følgeforskningen til projekt Fagligt Entreprenørskab har været optaget af at besvare forskningsspørgsmålene:

- Hvordan kan den entreprenørskabsundervisning, som genereres i udviklingsprojektet, påvirke elevers læring, motivation og lyst til at deltage i uddannelse?

- Herunder hvordan elever, der har særlige udfordringer, kan profitere af denne form for undervisning?

Der er løbende gennem delanalyserne og i den opsamlende analyse, lavet opsamling ift. motivation og læring i sammenhæng til de tre analytiske blik, som har været analysens omdrejningspunkter. Kort betyder det, at analysen har omhandlet forståelse for tegn på læring, motivation og hvordan motivation og læring kan identificeres gennem lærernes didaktisk praksis, herunder elevernes deltagelse i undervisningseksperimenterne.

Her vil vi ganske kort opridse de centrale fund ift. hvorledes undervisningseksperimenterne synes at påvirke elevernes motivation og læring. Dette vil danne afsæt for, hvordan analysens resultater (illustreret gennem de 5 didaktiske forhold) kan sætte retning for en udvidet forståelse af entreprenørskabsundervisning, og den deri indlejrede entreprenørskabsdidaktik. Vi vil komme med bud på, hvilke dimensioner i entreprenørskabsundervisning, der synes væsentlige at styrke fremadrettet, for at understøtte elevers motivation og læring.

De undervisningseksperimenter der er blevet udvalgt til følgeforskningen er valgt fordi de omhandler didaktiske eksperimenter, hvor didaktiske greb, der har haft til formål at fremme entreprenørielle kompetencer hos eleverne, er blevet afprøvet. Undervejs i denne analyse er givet mange eksempler på undervisningsforløb, der klart synes at være motivations- og læringsfremmende. De mange lærer- og elevudsagn bekræfter dette. Hvad der er særligt interessant er, at flere steder, ikke blot synes undervisnings-eksperimenterne at fremme motivation og læring, de kan også kendetegnes ved at:

- Eleverne tager medansvar for læring og viser ejerskab over læreprocessen. F.eks. er der flere eksempler, hvor eleverne tydeligt fortæller, hvad der virker understøttende for deres læreproces. Hvordan elev-lærerrelationen skal være. Hvordan relationer til de andre elever skal være. Og hvordan opgaverne bedst stilles, så de virker motiverende. 
- Eksperimenterne udvider læringsindholdet. Med det menes, at eleverne ikke bare lærer mere eller er mere motiverede men, at de lærer anderledes og herigennem ser ud til at have et kvalitativt andet læringsudbytte. F.eks. viser analysen, at flere elever, der begejstret og ivrigt fortæller om deres opgaver under uddannelsen og deres uddannelse i øvrigt. Dette er ikke skole, siger de. Og de giver udtryk for, at de slet ikke 'mærker læringen komme ind' og der er selvforglemmende stunder, der kan karakteriseres som det at være i flow.

- Eleverne overkommer udfordringer. Der er flere eksempler på elever, der arbejder ihærdigt med at overstige og komme igennem svære opgaver - de erfarer at lære med møje (Hermansen, 2012).

- Fællesskaber om opgaver beriger elevernes lærerprocesser. Der er flere eksempler på, hvorledes fællesskabet mellem eleverne er stærkt berigende for læreprocessen, ikke blot til gensidig inspiration, men selve det at deltage og inkluderes i fællesskabet synes at være særligt styrkende.

- Elever trives med lærerrelationer i øjenhøjde. Eksempler viser, at eleverne klart foretrækker lærerrelationer, hvor læreren i højere grad står ved siden af eleven (i øjenhøjde) og ofte også bagved (støttende) mere end foran (doserende). Eleven ønsker at indgå i mere ligeværdige relationer med læreren og viser også tydeligt, at de kan og vil bruge lærerens ekspertise - især hvis ekspertisen 'gives', når eleven er opsøgende.

- Motivation og læring kan være gensidigt forstærkende. Motivation er ikke blot forudsætning for læring. Læring kan også berige motivationen. Vi så flere eksempler på, hvorledes læreprocesserne synes at styrke den videre motivation.

- Motivation kan være et resultat af undervisningen og beriges, når eleven mødes på sine motivationsorienteringer og undervisningen giver mulighed for, at eleven kan følge disse orienteringer, f.eks. ved, at eleven kan arbejde med opgaver, der er personligt involverende og meningsfulde.

Det interessante er, at det ser ud til at mindre eller måske mere præcist udtrykt anderledes struktur og rammesætning samt mindre klassisk lærerstyring og mere proces - og organisationsstyring synes at berige og fremme motivation og læring. Dette er især aspekter, der blev trukket frem i tredje blik under analyse af elever med særlige udfordringer. Her er der også relateret til anden forskning, der modsat denne følgeforskning angiver, at elever med særlige udfordringer didaktisk bør mødes med klassisk skolestruktur og overskuelige rammer. Denne undersøgelse synes altså at give et mere nuanceret billede, hvad struktur, styring og rammer i en mere faciliterende form betyder. Som vi skrev indledningsvist, er der andet forskning fremhævet i forstudiet (Day, Larsen og Sørensen 2016), der ligesom denne analyse peger på at arbejde praktisk i fællesskaber med mulighed for en vis selvbestemmelse, hvor man kan se, hvad man skal lære og hvorfor det er relevant, og gøre noget der har værdi for andre, kan virke motiverende og fastholdende - også for elever med særlige udfordringer

Igennem analyserne, er der identificeret en række didaktiske greb, som særligt synes at fremme elevernes entreprenørielle kompetencer. Disse didaktiske greb er, som tidligere nævnt, samlet under 5 tværgående didaktiske forhold, som er betydningsfulde at tænke ind i læreres design af entreprenørskabsundervisning:

De fem didaktiske forhold er:

- Undervisningsformer, metoder og indhold, der åbner for aktiv deltagelse

- Samarbejde om opgaven og relationer i sammenhæng dertil

- Lærerroller i øjenhøjde, der faciliterer og skubber

- Praksislæring og samspil med omverdenen

- Mestring gennem aktiv handlen og medbestemmelse 
De 5 didaktiske forhold skal forstås sådan, at der er særlige greb ift. hvert af de nævnte didaktiske forhold, der synes at fremme ikke kun elevernes motivation og læring, men også éntreprenørielle kompetencer og et entreprenant mindset.

Analysen har vist, at undervisningsforløbene har haft en positiv betydning for elevernes motivation og læring. Det er også blevet vist hvordan - i forståelsen hvornår og i hvilke situationer motivation og læring særligt synes at påvirkes.

De eksempler hvor eleverne særligt synes at være motiverede og i læring, synes klart at være situationer, hvor eleverne arbejder problemorienteret (udfordrings - og behovsdrevet), mulighedsorienteret (f.eks. åbne opgaver - uden fast indhold, mål og tid), eksperimenterende (f.eks. når eleverne arbejder undersøgende, forbedre deres aktiviteter, produkter eller processer og finder på nyt, f.eks. nye lege til daginstitutioner). Didaktisk lægger disse undervisningsformer tæt op af forløb, som eleverne omtalte som særligt positive og givende - nemlig forløb med lav grad af traditionel struktur, rammesætning og lærerstyring. Vi peger på, at didaktiske greb af betydning for udvikling af undervisning der kan karakteriseres som fagligt entreprenørskab i erhvervsuddannelserne er, at de samskabende processer har en særlig positiv betydning ift. ikke blot, at eleverne bruger hinandens ressourcer ved gruppearbejde, men at fællesskabet synes at udgøre en egen læringsressource ved at være inkluderende og give fælles oplevelser af mestring. Ligesom det også er tydeligt at samskabende processer, hvor omverdenen bliver inddraget, syntes at være særligt fremmende for motivation og læring. Entreprenørskabsundervisning udlagt som fagligt entreprenørskab i erhvervsuddannelserne synes at fremme en forestilling om eleverne som aktører i branchen, og det bringer nye læringsmuligheder med sig. Læringsrummet bliver udvidet; det rækker ud over klassen og eleverne inddrager viden og erfaringer de har med sig fra for eksempel praktikken (fortid) lige som der bliver skabt viden i relation til drømme om fremtiden. De innovative aspekter synes deslige at være værdifulde for eleverne. Det synes klart personligt involverende for eleverne, når læringsprodukterne har til hensigt at skabe værdi for andre, for eksempel forstået sådan, at elevernes deltagelse i opgaveløsninger, der involverer virkelige/autentiske forhold er særligt motiverende.

Under vores afdækning af, hvad entreprenørskabsundervisning er, fremhæver vi indledningsvis en undersøgelse, der illustrer karaktertræk ved entreprenørskabsundervisning i relation til andre tilstødende undervisningsformer (Lackéus, Lundqvist \& Williams-Middleton, 2015). Heraf fremgår det at entreprenørskabsundervisning udmærker sig ved at være:

- Problemorienteret: Problemer som afsæt for idéer og løsninger.

- Mulighedsorienteret: Mulighedsorienterede processuelle forløb, dvs. hvor mål ikke er klart afgrænsede/definerede.

- Eksperimenterende: Eksperimenterende og undersøgende tilgang, hvor det er naturligt at mislykkes og prøve igen.

- Innovativ: At være innovativ og nyskabende med det formål at skabe værdi for andre.

- Samskabende: Samskabende processer, hvor eleverne samarbejder med hinanden om at løse praksisnære og autentiske opgaver.

Knytter vi vores resultater med ovenstående rammesætning af entreprenørskabsundervisning er der i analysen konkrete bud på, hvilken didaktisk praksis, der kan folde entreprenørskabsundervisning ud og, at denne didaktik synes at være særligt lærings- og motivationsfremmende.

Nærværende projekt har gennem sine mange detaljerede praksiseksempler udfoldet et blik på undervisning omhandlende entreprenørskab, samt bagvedliggende lærings- og motivationssyn, samt identificeret en række didaktiske greb, forhold og overvejelser, der er vigtige for at arbejde med at udvikle erhvervsskoleelevers entreprenørielle kompetencer fremadrettet. 


\section{Litteraturliste}

Bach, K. og Olesen, M. (2011) Vidensopsamling. Eksisterende viden om ledige unge under 30 år, udarbejdet i samarbejde med Beskæftigelsesregionerne Hovedstaden \& Sjælland, Nordjylland, Midtjylland og Syddanmark. Marselisborg Praksisvidencenter (2011).

Beck, S., Kaspersen, P. \& Paulsen, M. (2014): Klassisk og moderne læringsteori. Hans Reitzel

Beyer, K. (1999). Det er ikke tænkning det hele. I: Hansen, B.G, m.fl.: Voksenliv og læreprocesser i det moderne samfund. Gyldendal. 1999. Opr. 1997.

Brink Larsen, N., Brodersen, A. \& Bjerre, C. (2015). Udsatte unge på erhvervsuddannelserne imellem inklusion, marginalisering og fragmentering? Institut for Pædagogisk og socialfaglig Efter- og videreuddannelse Professionshøjskolen, Metropol

Brinkmann, (2007). Motivation gennem handling og gøremål - et pragmatisk perspektiv: KvaN 78.

Brown, A. L. (1992). Design Experiments: Theoretical and Methodological Challenges in Creating Complex Interventions in Classroom Settings. The Journal of the Learning Sciences,

Cobb, P., Confrey, J., diSessa, A. A., Lehrer, R., \& Schauble, L. (2003). Design Experiments in Educational Research. Educational Researcher, 32(1), 9-13.

Collins, A. (1992). Toward a Design Science of Education. In E. Scanlon \& T. O'Shea (Eds.), New directions in educational technology (pp. 15-22). Berlin: Springer-Verlag.

Dysthe, O. (2001). Dialog, samspil og læring, pædagogiske linjer. Klim.

Day, B., Larsen, J. og Sørensen D. (2016). Forstudie: Entreprenørskabsundervisning - Sammenhæng til motivation, læring og lyst til uddannelse.

Duus, Husted, kildedal, Laursen og Tofteng (2012) kap. 10 (Duus) Aktionseksperimentet i Aktionsforskning - en grundbog Samfundslitteratur

Forskningsprojekt om fastholdelse af erhvervsskoleelever i det danske erhvervsuddannelsessystem - kort version 2013. http://psy.au.dk/fileadmin/Psykologi/Forskning/Forskningsprojekter/Fastholdelse af erhvervsskoleelever/Populaerversion280813finalrev.pdf

Fonden for Entreprenørskab (2011). Impact of entrepreneurship education in Denmark 2010. Odense: Young Enterprise

Fonden for Entreprenørskab (2016). Taksonomi i entreprenørskabsuddannelse - perspektiver på mål, undervisning og evaluering. 2. udgave, tilgået fra: www.ffe-ye.dk/videncenter, $\mathrm{d}$. 09/04/2017

Fonden for Entreprenørskab (2014). Effektmåling af entreprenørskab - undervisning i Danmark. Tilgået fra: http://www.ffe-ye.dk/media/504981/effektmaalingen-2015-til-net.pdf, d. 09/04/2017

Lackéus, Lundqvist \& Williams-Middleton (2015).

Geiger, T. (2015). How to create innovative mindsets: Dialog. Nordiskt nätverk för vuxnas lärande (NVL).

Gravemeijer, K., \& Coob, P. (2006). Design Research from a learning design perspective. In J. V. D. Akker, K. 
Gravemeijer, S. McKenney \& N. Nieveen (Eds.), Educational Design Research . London \& New York: Routledge.

Greve, L. og Kirketerp, A., (2011). Entreprenørskabsundervisning. Aarhus Universitetsforlag

Hermansen, M (2005/2012): Om læring - minimalisme i læringsteori. I: Illeris,K (red)(2012): 49 tekster om læring. Samfundslitteratur.

Hersom, Henrik 2017: Praksislæring i erhvervsuddannelserne i Ind i praksis. Hersom et al. (red. Hersom, Henrik \& Koudahl, Peter). Foreløbig titel. In press. Forlaget Praxis.

Hutters, C. og Sørensen, D. (2015) Uddannelseseksperimenter -metode, teori og praksis. En introduktion: Det Erhvervsrettede uddannelseslaboratorium i region Hovedstaden.

Hutters, C \& Sørensen, D. (2015) Håndbog til eksperimenthjulet - sådan arbejder du med uddannelseseksperimenter i praksis: Det Erhvervsrettede uddannelseslaboratorium i region Hovedstaden.

Illeris, K. (2006). Læring. København: Roskilde Universitetsforlag.

Illeris, K. (2013). Læringsmiljø skal skabes - motivation skal findes. I Sørensen, N.U., Hutters, C., Katznelson, N. \& Juul, T.M.: Unges motivation og læring. 12 eksperter om motivationskrisen i uddannelsessystemet. København: Hans Reitzels Forlag.

Jank, W. og Meyer, H., (2006). Didaktiske modeller: grundbog i didaktik. Gyldendal

Lave, J. \& Wenger, E. (2003). Situeret læring og andre tekster. Hans Reitzels Forlag.

Lucas, B. (2014). Vocational pedagogy - What it is, why it matters and what we can do about it. background Note for UNESCO-UNEVOC e-Forum

Koch, Hans og Sørensen, Dorrit (2010) Fra strategi til praksis - implementering af innovation i erhvervsuddannelserne. NCE, Metropol

Koch, Hans og Sørensen, Dorrit (2017) Koncept for uddannelsesforløb i Faglig Entreprenørskab på diplomniveau - Værdier, principper og forløbsbeskrivelse. NCE, Metropol

Ministeriet for Forskning, Innovation og Videregående Uddannelse (december, 2012). Danmark - Løsningernes Land, Styrket samarbejde og bedre rammer for innovation i virksomhederne. Tilgået fra: http://ufm.dk/publikationer/2012/danmark-losningernes-land, d. 09/04/2017

Moberg, K., (2014). Two Approaches to Entrepreneurship Education: The Different Effects of Education For and Through Entrepreneurship at the Lower Secondary Level. Accepted for publication in The International Journal of Management Education

Newman (1991) i Rasmussen, A., Moberg, K. \& Revsbech, C. (2015). Taksonomi i Entreprenørskabsuddannelse - perspektiver på mål, undervisning og evaluering. Odense: www.ffe-ye.dk

Nybye, N. \& Rasmussen, A. (2013). Progressionsmodel: Entreprenørskabs- og innovationsundervisning. Fonden for Entreprenørskab - Young Enterprise. Odense. www.ffe-ye.dk

Pittaway, L. og Edwards, C., (2012). Assessment: examining practice in entrepreneurship education. Education + Training 
Pless, M., Katznelson, N., Hjort-Madsen, P. og Nielsen, A. M. W. (2015). Unges motivation i udskolingen. Et bidrag til teori og praksis om unges lyst til læring i og uden for skolen, Ålborg Universitetsforlag

Rasmussen, A., Moberg, K. \& Revsbech, C. (2015). Taksonomi i Entreprenørskabsuddannelse - perspektiver på mål, undervisning og evaluering. Odense. www.ffe-ye.dk

Persson Sven (2008) Forskningscirkler- en vejledning. Malmö Stad

Sørensen, N.U., Hutters, C., Katznelson, N. \& Juul, T.M. (2013). Unges motivation og læring. 12 eksperter om motivationskrisen i uddannelsessystemet. København: Hans Reitzels Forlag.

TECs hjemmeside, automatik og procesuddannelsen, http://www.tec.dk/erhvervsuddannelse/automatik-og-procesuddannelsen/ , tilgået 09/04/2017

Wahlgren, B., Pedersen, S.H., Voigt, J.R. \& Gundersen, P. (2009). Motivation og læringsform. En oversigt over eksisterende forskning. København: Nationalt Center for Kompetenceudvikling.

Wenger, E. (2004). Praksis fællesskaber: Hans Reitzels Forlag.

Wenger, E. (1998). Communities of Practice. Learning, Meaning and Identity. Cambridge: Cambridge University Press. 